Supporting Information for

\title{
Copper-Catalyzed Defluorinative Borylation and Silylation of gem-Difluoroallyl Groups
}

\author{
Trevor W. Butcher, ${ }^{\star}$ Jonathan L. Yang, ${ }^{\star}$ and John F. Hartwig*
}

\section{TABLE OF CONTENTS}

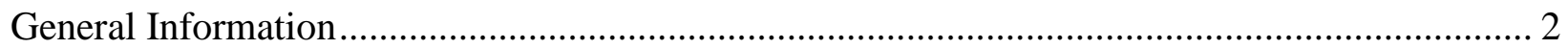

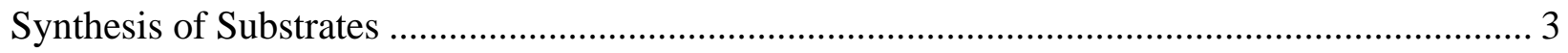

Defluorinative Borylation of 3-Substituted 3,3-Difluoropropenes .......................................... 5

Characterization of Crude Allylboronic Esters ............................................................ 7

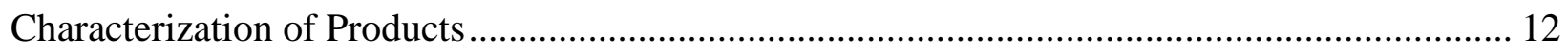

Derivatization of Defluorinative Borylation Products ....................................................... 19

Defluorinative Silylation of 3-substituted 3,3-difluoropropenes ......................................... 21

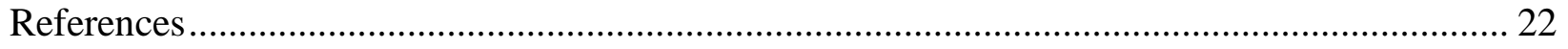

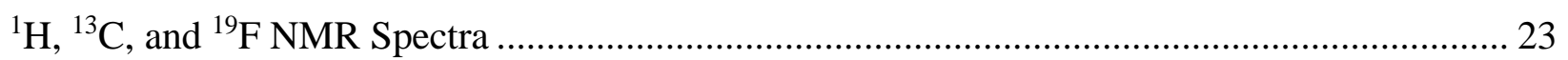

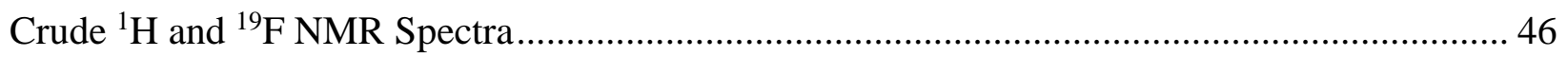

These authors contributed equally. 


\section{GENERAL INFORMATION}

All air-sensitive manipulations were conducted under an inert atmosphere in a nitrogenfilled glovebox or by standard Schlenk techniques. Reactions conducted in vials (for example, the copper-catalyzed defluorinative borylations) were heated in a metal heating block, and reactions conducted in Schlenk flasks (for example, those for the synthesis of substrates) were heated in an oil bath. Unless stated otherwise, reagents and solvents were purchased from commercial suppliers and used without further purification. Tetrahydrofuran was purified by passing it through a solvent column composed of activated A-1 alumina and degassed by the freeze-pump-thaw method.

Proton nuclear magnetic resonance $\left({ }^{1} \mathrm{H}\right.$ NMR) spectra were acquired on commercial instruments $(300,400,500$ and $600 \mathrm{MHz})$ at the NMR facility of the University of California, Berkeley. Carbon-13 nuclear magnetic resonance $\left({ }^{13} \mathrm{C}\right.$ NMR $)$ spectra were acquired at $151 \mathrm{MHz}$. Fluorine-19 nuclear magnetic resonance ( ${ }^{19} \mathrm{~F}$ NMR) spectra were acquired at $565 \mathrm{MHz}$. Chemical shifts are reported relative to residual solvent peaks $\left(\mathrm{CDCl}_{3}=7.26 \mathrm{ppm}, \mathrm{CD}_{2} \mathrm{Cl}_{2}=5.32 \mathrm{ppm}\right.$, $\mathrm{CD}_{3} \mathrm{CN}=1.94 \mathrm{ppm}$, Acetone- $d_{6}=2.04 \mathrm{ppm}$, and $\mathrm{C}_{6} \mathrm{D}_{6}=7.16 \mathrm{ppm}$ for ${ }^{1} \mathrm{H} \mathrm{NMR}$ spectra and $\mathrm{CDCl}_{3}$ $=77.16 \mathrm{ppm}, \mathrm{CD}_{2} \mathrm{Cl}_{2}=53.5 \mathrm{ppm}, \mathrm{CD}_{3} \mathrm{CN}=1.32 \mathrm{ppm}$ (methyl resonance), Acetone- $d_{6}=29.8 \mathrm{ppm}$ (methyl resonance), and $\mathrm{C}_{6} \mathrm{D}_{6}=128.1 \mathrm{ppm}$ for ${ }^{13} \mathrm{C}$ NMR spectra). For ${ }^{19} \mathrm{~F}$ NMR spectra, chemical shifts are reported relative to the $\delta-113.15$ resonance of $\mathrm{PhF}$ used as an external reference. The following abbreviations are used in reporting NMR data: s, singlet; $d$, doublet; $t$, triplet; q, quartet; p, pentet; hept, heptet; AB, AB quartet; m, multiplet; br, broad.

High-resolution mass spectra were recorded on a commercial high-resolution mass spectrometer at the Micro Mass Analytical Facility operated by the College of Chemistry, University of California, Berkeley, or with an Agilent Time of Flight (Q-TOF) mass spectrometer in ESI mode. Optical rotations were measured on a Perkin Elmer 241 Automatic Polarimeter. Analytical thin layer chromatography (TLC) was performed on Kieselgel 60 F254 glass plates precoated with a $0.25 \mathrm{~mm}$ thickness of silica gel. The TLC plates were visualized with UV light and by staining with $\mathrm{KMnO}_{4}$. Column chromatography was generally performed on a Teledyne Isco Combiflash ${ }^{\circledR} \mathrm{R}_{f}$ system with RediSep Gold ${ }^{\mathrm{TM}}$ columns. 


\section{SYNTHESIS OF SUBSTRATES}

Fluorinated allylic electrophiles $\mathbf{1 a}-\mathbf{1 h}$ were prepared in one step from commercially-available arylboronic acids according to the protocol reported by Zhang and coworkers. ${ }^{1}$ Fluorinated allylic electrophiles $\mathbf{1} \mathbf{i}^{2}$ and $\mathbf{1} \mathbf{j}^{3}$ were prepared by Barbier reaction of 3-bromo-3,3-difluoropropene and the appropriate carbonyl compound in one step according to the literature.

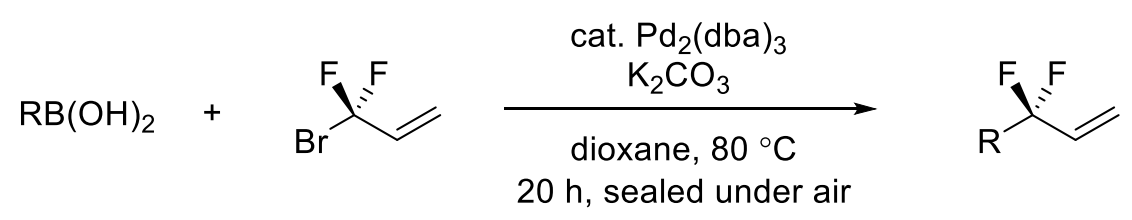

Allylic electrophiles 1a, 1c, 1d, 1f-1h are known compounds as reported by Zhang and coworkers. ${ }^{1}$ Allylic electrophiles $\mathbf{1 b}$ and $\mathbf{1 e}$ were reported in a recent report by us; ${ }^{3}$ precise details of their synthesis are also given below.

\section{(1,1-difluoroallyl)benzene (1b)}<smiles>C=CC(F)(F)c1ccccc1</smiles>

The title compound was prepared according to the following procedure. The reaction was conducted under air. Phenylboronic acid (365.8 mg, 3.000 mmol, 1 equiv) and $\mathrm{K}_{2} \mathrm{CO}_{3}(1.244 \mathrm{~g}$, $9.000 \mathrm{mmol}, 3.000$ equiv) were weighed directly into a $50 \mathrm{~mL}$ Schlenk flask with a single opening sealed with a Teflon plug and containing a magnetic stir bar. $\mathrm{Pd}_{2}(\mathrm{dba})_{3}(11.0 \mathrm{mg}, 12.0 \mu \mathrm{mol}, 0.400$ mol \%) was added, followed by dry dioxane $(15.0 \mathrm{~mL})$ and distilled water $(27.0 \mu \mathrm{L}, 1.50 \mathrm{mmol}$, 0.500 equiv). Lastly, 3-bromo-3,3-difluoropropene ( $495 \mu \mathrm{L}, 4.50 \mathrm{mmol}, 1.50$ equiv) was added. The Schlenk flask was sealed, and the reaction mixture was stirred vigorously and heated at $80{ }^{\circ} \mathrm{C}$ in an oil bath for $20 \mathrm{~h}$. After this time, the reaction mixture was cooled to ambient temperature, diluted with THF, and filtered through a pad of magnesium sulfate. Due to the volatility of the product, the crude reaction mixture was carefully concentrated under vacuum at $0{ }^{\circ} \mathrm{C}$. The product was then purified by silica gel column chromatography (0/100 to $10 / 90$ of ether/pentane) to provide (1,1-difluoroallyl)benzene (1b) as a clear, colorless liquid (188.5 mg, $1.223 \mathrm{mmol}, 41 \%)$. Note: It is important that the reaction vessel has little headspace and that the entire vessel is submerged in the heating bath. 
${ }^{1} \mathbf{H}$ NMR $\left(600 \mathrm{MHz}, \mathrm{CDCl}_{3}\right) \delta 7.52(\mathrm{ddt}, J=5.3,3.1,1.6 \mathrm{~Hz}, 2 \mathrm{H}), 7.44(\mathrm{dd}, J=5.2,2.0 \mathrm{~Hz}, 3 \mathrm{H})$, 6.17 (ddt, $J=17.3,11.0,9.7 \mathrm{~Hz}, 1 \mathrm{H}), 5.58$ (dt, $J=17.2,2.8 \mathrm{~Hz}, 1 \mathrm{H}), 5.49$ (d, $J=10.9 \mathrm{~Hz}, 1 \mathrm{H})$.

${ }^{13} \mathrm{C}$ NMR $\left(151 \mathrm{MHz}, \mathrm{CDCl}_{3}\right) \delta 136.4(\mathrm{t}, J=27.4 \mathrm{~Hz}), 134.0(\mathrm{t}, J=30.2 \mathrm{~Hz}), 130.1(\mathrm{t}, J=1.8 \mathrm{~Hz})$, 128.6, $125.6(\mathrm{t}, J=5.7 \mathrm{~Hz}), 119.9(\mathrm{t}, J=9.3 \mathrm{~Hz}), 119.5(\mathrm{t}, J=238.3 \mathrm{~Hz})$.

${ }^{19}$ F NMR $\left(565 \mathrm{MHz} \mathrm{CDCl}_{3}\right) \delta-94.6(\mathrm{dd}, J=9.7,2.8 \mathrm{~Hz})$.

HRMS (EI): $m / z$ for $\mathrm{C}_{9} \mathrm{H}_{8} \mathrm{~F}_{2}[\mathrm{M}]^{+}$calcd.: 154.0594 , found: 154.0593

\section{1-(1,1-difluoroallyl)-4-(trifluoromethyl)benzene (1e)}

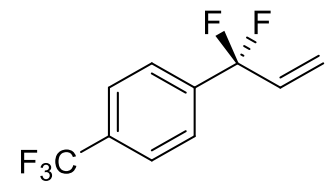

The title compound was prepared according to the following procedure. The reaction was conducted under air. 4-(Trifluoromethyl)phenylboronic acid (569.8 mg, $3.000 \mathrm{mmol}, 1$ equiv) and $\mathrm{K}_{2} \mathrm{CO}_{3}$ (1.244 g, $9.000 \mathrm{mmol}, 3.000$ equiv) were weighed directly into a $50 \mathrm{~mL}$ Schlenk flask with a single opening sealed with a Teflon plug and containing a magnetic stir bar. $\mathrm{Pd}_{2}(\mathrm{dba})_{3}(11.0 \mathrm{mg}$, $12.0 \mu \mathrm{mol}, 0.400 \mathrm{~mol} \%)$ was added, followed by dry dioxane $(15.0 \mathrm{~mL})$ and distilled water $(27.0$ $\mu \mathrm{L}, 1.50 \mathrm{mmol}, 0.500$ equiv). Lastly, 3-bromo-3,3-difluoropropene (495 $\mu \mathrm{L}, 4.50 \mathrm{mmol}, 1.50$ equiv) was added. The Schlenk flask was sealed and the reaction mixture was stirred vigorously and heated at $80{ }^{\circ} \mathrm{C}$ in an oil bath for $20 \mathrm{~h}$. After this time, the reaction mixture was cooled to ambient temperature, diluted with THF, and filtered through a pad of magnesium sulfate. Due to the volatility of the product, the crude reaction mixture was carefully concentrated under vacuum at $0{ }^{\circ} \mathrm{C}$. The product was then purified by silica gel column chromatography $(0 / 100$ to $10 / 90$ of ether/pentane) to provide difluoroallylarene 1e as a clear, colorless liquid (261.5 mg, $1.177 \mathrm{mmol}$, $39 \%)$. Note: It is important that the reaction vessel has little headspace and that the entire vessel is submerged in the heating bath.

${ }^{1} \mathbf{H}$ NMR $\left(600 \mathrm{MHz}, \mathrm{CDCl}_{3}\right) \delta 7.70(\mathrm{~d}, J=8.2 \mathrm{~Hz}, 2 \mathrm{H}), 7.64(\mathrm{~d}, J=8.1 \mathrm{~Hz}, 2 \mathrm{H}), 6.15(\mathrm{ddt}, J=$ $17.3,10.9,9.8 \mathrm{~Hz}, 1 \mathrm{H}), 5.59$ (dt, $J=17.3,2.8 \mathrm{~Hz}, 1 \mathrm{H}), 5.53(\mathrm{~d}, J=10.9 \mathrm{~Hz}, 1 \mathrm{H})$.

${ }^{13} \mathrm{C}$ NMR $\left(151 \mathrm{MHz}, \mathrm{CDCl}_{3}\right) \delta 140.1(\mathrm{t}, J=27.8 \mathrm{~Hz}), 133.3(\mathrm{t}, J=29.7 \mathrm{~Hz}), 132.3(\mathrm{q}, J=32.7$ Hz), 126.3 (t, $J=5.6 \mathrm{~Hz}), 125.7$ (q, $J=3.8 \mathrm{~Hz}), 123.9$ (q, $J=272.4 \mathrm{~Hz}), 120.7$ (t, $J=9.3 \mathrm{~Hz})$, $118.8(\mathrm{t}, J=239.2 \mathrm{~Hz})$.

${ }^{19}$ F NMR $\left(565 \mathrm{MHz}, \mathrm{CDCl}_{3}\right) \delta-63.9,-95.4(\mathrm{dd}, J=9.7,2.5 \mathrm{~Hz})$.

HRMS (EI): $m / z$ for $\mathrm{C}_{10} \mathrm{H}_{7} \mathrm{~F}_{5}$ [M] $]^{+}$calcd.: 222.0468, found: 222.0464 . 


\section{DEFLUORINATIVE BORYLATION OF 3-SUBSTITUTED 3,3-DIFLUOROPROPENES}

\section{1) General Procedure for Investigation of Scope}

\section{Step 1: Defluorinative Borylation}

In a nitrogen-filled glovebox, a stock solution of $\mathrm{CuCl}$ and $\mathrm{PCy}_{3}$ in $\mathrm{THF}$ was prepared (20.0 mol $\%, 0.0400 \mathrm{mmol} \mathrm{CuCl}$ and $20.0 \mathrm{~mol} \%, 0.0400 \mathrm{mmol}$ РСуз per $400 \mu \mathrm{L} \mathrm{THF}$ ). The solution was allowed to stir at room temperature for 20 minutes, at which time neat $\mathrm{NaO}$ - $\mathrm{Bu}$ was added (40.0 mol \%, $0.0800 \mathrm{mmol}$ per $400 \mu \mathrm{L}$ THF), and the subsequent solution was allowed to stir at room temperature for 1 hour. Separately, a $4 \mathrm{~mL}$ vial equipped with a stir bar was charged with the 3substituted 3,3-difluoropropene (1.00 equiv, $0.200 \mathrm{mmol})$ and a $400 \mu \mathrm{L}$ aliquot of the prepared catalyst solution. The resulting mixture was allowed to stir for 10 seconds, after which time neat bis(pinacolato)diboron (2.00 equiv, $0.400 \mathrm{mmol}$ ) was added. The the reaction mixture immediately turned a dark orange-brown. The reaction vial was then sealed with a PTFE cap and was heated at $45^{\circ} \mathrm{C}$ in a metal heating block with stirring for 5 hours. After this time, the reaction was diluted with of $\mathrm{CDCl}_{3}(1.00 \mathrm{~mL}$ ) and fluorobenzene (internal standard, $80.0 \mu \mathrm{L}$ ) was added. The resulting mixture was thoroughly mixed, and an aliquot was analyzed via ${ }^{1} \mathrm{H}$ NMR and ${ }^{19} \mathrm{~F}$ NMR spectroscopy. The NMR sample and bulk material were combined, and the reaction mixture was diluted with $30 \mathrm{~mL}$ of diethyl ether and washed with $1 \mathrm{M} \mathrm{HCl}(3 \times 30 \mathrm{~mL})$, water $(30 \mathrm{~mL})$, and brine $(30 \mathrm{~mL})$. The organic layer was dried over sodium sulfate, and the solvent was evaporated under vacuum in a $100 \mathrm{~mL}$ round-bottomed flask to provide the crude allylic boronic ester.

\section{Step 2: Oxidation to the Allylic Alcohol}

The $100 \mathrm{~mL}$ round bottom flask containing the crude allylic boronic ester from Step 1 was equipped with a stir bar and charged with tetrahydrofuran $(1.8 \mathrm{~mL})$. The resulting solution was cooled to $0{ }^{\circ} \mathrm{C}$ with an ice bath, and aqueous $3 \mathrm{M} \mathrm{NaOH}(1.2 \mathrm{~mL})$ was added dropwise, followed by immediate dropwise addition of aqueous hydrogen peroxide with a plastic syringe $(950 \mu \mathrm{L}$, $34 \%$ by mass in $\mathrm{H}_{2} \mathrm{O}$ ). Following the addition of hydrogen peroxide, the reaction mixture turned dark brown. The reaction mixture was stirred in an ice bath, where it was allowed to slowly warm to room temperature overnight $(14 \mathrm{~h})$. After this time, the reaction mixture was again cooled to 0 ${ }^{\circ} \mathrm{C}$ and was quenched by dropwise addition of $2 \mathrm{M}$ sodium thiosulfate. The mixture was extracted with dichloromethane $(3 \times 50 \mathrm{~mL})$, the combined organic layers were dried over sodium sulfate, and the solvent was removed under vacuum. The resulting residue was subjected to silica-gel column chromatography to provide pure allylic alcohol 4. 


\section{2) General Procedure for Investigation of Reaction Conditions}

In a nitrogen-filled glovebox, a stock solution of $\mathrm{CuCl}$ and ligand or pre-formed copper catalyst in THF was prepared $(1.0 \mathrm{mg}, 20 \mathrm{~mol} \%, 0.010 \mathrm{mmol} \mathrm{CuCl}$ and $20 \mathrm{~mol} \%, 0.010 \mathrm{mmol}$ ligand or 20 mol \%, $0.010 \mathrm{mmol}$ pre-ligated copper complex per $100 \mu \mathrm{L}$ THF). The resulting solution was allowed to stir for 20 minutes, after which time a neat alkali metal tert-butoxide base was added ( 0.20 equiv- 2.00 equiv, $0.010-0.100 \mathrm{mmol}$ ), and the subsequent solution was allowed to stir for 30 minutes. Separately, a $4 \mathrm{~mL}$ vial equipped with a stir bar was charged with 2-(1,1difluoroallyl)naphthalene (1a) $(10.2 \mathrm{mg}, 1.00$ equiv, $0.0500 \mathrm{mmol})$. A $100 \mu \mathrm{L}$ aliquot of the prepared catalyst solution was added, and the resulting solution was allowed to stir for 10 seconds before adding neat bis(pinacolato)diboron $(25.4 \mathrm{mg}, 2.00$ equiv, $0.100 \mathrm{mmol})$. The reaction vial was then sealed and heated at $45{ }^{\circ} \mathrm{C}$ in a metal heating block with stirring for 5 hours. After this time, the reaction was diluted with $\mathrm{CDCl}_{3}(700 \mu \mathrm{L})$, and fluorobenzene (internal standard, 20.0 $\mu \mathrm{L}$ ) was added. The resulting mixture was thoroughly mixed, and an aliquot was removed and analyzed via ${ }^{1} \mathrm{H}$ and ${ }^{19} \mathrm{~F}$ NMR spectroscopy.

\section{3) Preparation of allylboronic ester $2 a$ on a $1 \mathrm{mmol}$ scale}

In a nitrogen-filled glovebox, a solution of $\mathrm{CuCl}$ and $\mathrm{PCy}_{3}$ in THF was prepared (19.8 mg, 0.200 $\mathrm{mmol}, 20.0 \mathrm{~mol} \% \mathrm{CuCl}$ and $58.9 \mathrm{mg}, 0.200 \mathrm{mmol}, 20.0 \mathrm{~mol} \% \mathrm{PCy}_{3}$ in $2.0 \mathrm{~mL}$ THF). The resulting solution was allowed to stir at room temperature for 20 minutes, after which time neat $\mathrm{NaO} t$ - $\mathrm{Bu}$ was added (38.4 mg, $0.400 \mathrm{mmol}, 40.0 \mathrm{~mol}$ ), and the subsequent solution was allowed to stir at room temperature for 1 hour. Then, neat 2-(1,1-difluoroallyl)naphthalene (1a) (204.2 mg, 1.00 mmol, 1.00 equiv) was added to the catalyst solution. The resulting mixture was allowed to stir for 10 seconds, after which time neat bis(pinacolato)diboron (507.8 mg, $2.00 \mathrm{mmol}, 2.00$ equiv) was added. The reaction vial was then sealed with a PTFE cap and was heated at $45{ }^{\circ} \mathrm{C}$ in a metal heating block with stirring for 5 hours. After this time, the resulting mixture was diluted with 30 $\mathrm{mL}$ of diethyl ether and washed with $1 \mathrm{M} \mathrm{HCl}(3 \times 30 \mathrm{~mL})$, water $(30 \mathrm{~mL})$, and brine $(30 \mathrm{~mL})$. The organic layer was dried over sodium sulfate, and the solvent was evaporated under vacuum in a $100 \mathrm{~mL}$ round-bottomed flask to provide the crude allylic boronic ester as a white powder (537.0 $\mathrm{mg}$ ). This material was used for the subsequent diversitifications without further purification. ${ }^{1} \mathrm{H}$ NMR analysis of the crude material suggested the product was obtained as a 1.3:1 mixture of the desired product and $\mathrm{B}_{2}$ pin $_{2}$. 


\section{Characterization of Crude Allylboronic Esters}

(Z)-2-(3-fluoro-3-(naphthalen-2-yl)allyl)-4,4,5,5-tetramethyl-1,3,2-dioxaborolane (2a)<smiles>FC(=CCBr)c1ccc2ccccc2c1</smiles>

Prepared according to the general procedure. Crude allylboronic ester $\mathbf{2 a}$ was characterized by ${ }^{1} \mathrm{H}$ and ${ }^{19} \mathrm{~F}$ NMR spectroscopy. Diagnostic resonances in the ${ }^{1} \mathrm{H}$ NMR spectrum are reported only.

${ }^{1} \mathbf{H}$ NMR $\left(600 \mathrm{MHz}, \mathrm{CDCl}_{3}\right) \delta 7.95(\mathrm{~s}, 1 \mathrm{H}), 7.87-7.74(\mathrm{~m}, 3 \mathrm{H}), 7.59(\mathrm{~d}, J=8.6 \mathrm{~Hz}, 1 \mathrm{H}), 7.50-$ $7.43(\mathrm{~m}, 2 \mathrm{H}), 5.67(\mathrm{dt}, J=37.1,7.9 \mathrm{~Hz}, 1 \mathrm{H})$.

${ }^{19}$ F NMR $\left(565 \mathrm{MHz}, \mathrm{CDCl}_{3}\right) \delta-103.4(\mathrm{~d}, J=22.3 \mathrm{~Hz}$, minor $E$-isomer $),-121.5(\mathrm{~d}, J=37.2 \mathrm{~Hz}$, major Z-isomer).

(Z)-2-(3-fluoro-3-phenylallyl)-4,4,5,5-tetramethyl-1,3,2-dioxaborolane (2b)<smiles>FC(=CCBr)c1ccccc1</smiles>

Prepared according to the general procedure. Crude allylboronic ester $\mathbf{2 b}$ was characterized by ${ }^{1} \mathrm{H}$ and ${ }^{19} \mathrm{~F}$ NMR spectroscopy. Diagnostic resonances in the ${ }^{1} \mathrm{H}$ NMR spectrum are reported only.

${ }^{1} \mathbf{H}$ NMR $\left(600 \mathrm{MHz}, \mathrm{CDCl}_{3}\right) \delta 5.51(\mathrm{dt}, J=37.1,7.9 \mathrm{~Hz}, 1 \mathrm{H})$.

${ }^{19}$ F NMR $\left.\left(565 \mathrm{MHz}, \mathrm{CDCl}_{3}\right) \delta\right),-103.4(\mathrm{~d}, J=22.5 \mathrm{~Hz}$, minor, $E$-isomer $),-121.5(\mathrm{~d}, J=37.1 \mathrm{~Hz}$, major, Z-isomer).

(Z)-2-(3-(4-(tert-butyl)phenyl)-3-fluoroallyl)-4,4,5,5-tetramethyl-1,3,2-dioxaborolane (2c)<smiles>CC(C)(C)c1ccc(/C(F)=C/CBr)cc1</smiles> 
Prepared according to the general procedure. Crude allylboronic ester $2 \mathbf{c}$ was characterized by ${ }^{1} \mathrm{H}$ and ${ }^{19} \mathrm{~F}$ NMR spectroscopy. Diagnostic resonances in the ${ }^{1} \mathrm{H}$ NMR spectrum are reported only.

${ }^{1} \mathbf{H}$ NMR $\left(600 \mathrm{MHz}, \mathrm{CDCl}_{3}\right) \delta 5.46(\mathrm{dt}, J=37.2,8.0 \mathrm{~Hz}, 1 \mathrm{H})$.

${ }^{19} \mathbf{F}$ NMR $\left(565 \mathrm{MHz}, \mathrm{CDCl}_{3}\right) \delta,-103.4(\mathrm{~d}, J=21.9 \mathrm{~Hz}$, minor $E$-isomer $),-121.4(\mathrm{~d}, J=37.3 \mathrm{~Hz}$, major $Z$-isomer).

(Z)-2-(3-(4-(benzyloxy)phenyl)-3-fluoroallyl)-4,4,5,5-tetramethyl-1,3,2-dioxaborolane (2d)<smiles>FC(=CCc1ccccc1)c1ccc(OCc2ccccc2)cc1</smiles>

Prepared according to the general procedure. Crude allylboronic ester $\mathbf{2 d}$ was characterized by ${ }^{1} \mathrm{H}$ and ${ }^{19} \mathrm{~F}$ NMR spectroscopy. Diagnostic resonances in the ${ }^{1} \mathrm{H}$ NMR spectrum are reported only.

${ }^{1} \mathbf{H}$ NMR $\left(600 \mathrm{MHz}, \mathrm{CDCl}_{3}\right) \delta 5.33(\mathrm{dt}, J=37.3,7.9 \mathrm{~Hz}, 2 \mathrm{H}), 5.04(\mathrm{~s}, 2 \mathrm{H})$.

${ }^{19} \mathbf{F ~ N M R}\left(565 \mathrm{MHz}, \mathrm{CDCl}_{3}\right) \delta,-120.5(\mathrm{~d}, J=37.2 \mathrm{~Hz}$, major Z-isomer), $-102.3(\mathrm{~d}, J=22.4 \mathrm{~Hz}$, minor $E$-isomer).

(Z)-2-(3-fluoro-3-(4-(trifluoromethyl)phenyl)allyl)-4,4,5,5-tetramethyl-1,3,2-dioxaborolane $(2 \mathrm{e})$<smiles>F/C(=C\Cc1ccccc1)c1ccc(C(F)(F)F)cc1</smiles>

Prepared according to the general procedure. Crude allylboronic ester $2 \mathbf{e}$ was characterized by ${ }^{1} \mathrm{H}$ and ${ }^{19} \mathrm{~F}$ NMR spectroscopy. Diagnostic resonances in the ${ }^{1} \mathrm{H}$ NMR spectrum are reported only.

${ }^{1} \mathbf{H}$ NMR $\left(600 \mathrm{MHz}, \mathrm{CDCl}_{3}\right) \delta 7.57(\mathrm{~s}, 4 \mathrm{H}), 5.65(\mathrm{dt}, J=36.6,8.0 \mathrm{~Hz}, 1 \mathrm{H})$.

${ }^{19}$ F NMR $\left(565 \mathrm{MHz}, \mathrm{CDCl}_{3}\right) \delta-62.7$ (s, both isomers), -105.1 (d, $J=22.4 \mathrm{~Hz}$, minor E-isomer), 122.2 (d, $J=36.6 \mathrm{~Hz}$, major Z-isomer). 


\section{(Z)-(4-(1-fluoro-3-(4,4,5,5-tetramethyl-1,3,2-dioxaborolan-2-yl)prop-1-en-1-}

yl)phenyl)methanol (2f)<smiles>OCc1ccc(/C(F)=C/CBr)cc1</smiles>

Prepared according to the general procedure. Crude allylboronic ester $2 \mathbf{f}$ was characterized by ${ }^{1} \mathrm{H}$ and ${ }^{19} \mathrm{~F}$ NMR spectroscopy. Diagnostic resonances in the ${ }^{1} \mathrm{H}$ NMR spectrum are reported only. 1H NMR (600 MHz, CDCl3) $\delta 5.48(\mathrm{dt}, J=37.1,7.9 \mathrm{~Hz}, 1 \mathrm{H}), 4.89$ (s, 2H).

${ }^{19}$ F NMR $\left(565 \mathrm{MHz}, \mathrm{CDCl}_{3}\right) \delta-103.5(\mathrm{~d}, J=22.5 \mathrm{~Hz}$, minor $E$-isomer $),-121.3(\mathrm{~d}, J=37.1 \mathrm{~Hz}$, major Z-isomer).

\section{(Z)-2-(3-(4-bromophenyl)-3-fluoroallyl)-4,4,5,5-tetramethyl-1,3,2-dioxaborolane (2g)}<smiles>F/C(=C\Cc1ccccc1)c1ccc(Br)cc1</smiles>

Prepared according to the general procedure. Crude allylboronic ester $\mathbf{2 g}$ was characterized by ${ }^{1} \mathrm{H}$ and ${ }^{19} \mathrm{~F}$ NMR spectroscopy. Diagnostic resonances in the ${ }^{1} \mathrm{H}$ NMR spectrum arereported only.

${ }^{1} \mathbf{H}$ NMR $\left(600 \mathrm{MHz}, \mathrm{CDCl}_{3}\right) \delta 5.50(\mathrm{dt}, J=36.8,7.9 \mathrm{~Hz}, 1 \mathrm{H})$.

${ }^{19}$ F NMR $\left(565 \mathrm{MHz}, \mathrm{CDCl}_{3}\right) \delta-104.2(\mathrm{~d}, J=22.2 \mathrm{~Hz}$, minor $E$-isomer), -121.7 (d, $J=36.9 \mathrm{~Hz}$, major Z-isomer).

\section{(Z)-2-(3-(2,5-dimethylphenyl)-3-fluoroallyl)-4,4,5,5-tetramethyl-1,3,2-dioxaborolane (2h)}<smiles>Cc1ccc(C)c(/C(F)=C/CCc2ccccc2)c1</smiles>

Prepared according to the general procedure. Crude allylboronic ester $\mathbf{2 h}$ was characterized by ${ }^{1} \mathrm{H}$ and ${ }^{19} \mathrm{~F}$ NMR spectroscopy. Diagnostic resonances in the ${ }^{1} \mathrm{H}$ NMR spectrum are reported only. 
${ }^{1} \mathbf{H}$ NMR $\left(600 \mathrm{MHz}, \mathrm{CDCl}_{3}\right) \delta 5.08(\mathrm{dt}, J=36.6,7.9 \mathrm{~Hz}, 1 \mathrm{H}), 2.34(\mathrm{~d}, J=2.8 \mathrm{~Hz}, 3 \mathrm{H}), 2.30(\mathrm{~s}$, $3 \mathrm{H})$.

${ }^{19} \mathbf{F}$ NMR $\left(565 \mathrm{MHz}, \mathrm{CDCl}_{3}\right) \delta-104.7(\mathrm{~d}, J=36.5 \mathrm{~Hz}$, major $Z$-isomer $),-94.9(\mathrm{~d}, J=19.4 \mathrm{~Hz}$, minor, $E$-isomer).

(Z)-1-(1-fluoro-3-(4,4,5,5-tetramethyl-1,3,2-dioxaborolan-2-yl)prop-1-en-1-yl)cyclohexan-1ol (2i)<smiles>OC1(/C=C/CBr)CCCC1</smiles>

Prepared according to the general procedure with the following modifications: $25 \mathrm{~mol} \% \mathrm{CuCl}+$ $\mathrm{PCy}_{3}, 50 \mathrm{~mol} \% \mathrm{NaOt}$-Bu RT, $20 \mathrm{~h}$. Crude allylboronic ester $2 \mathbf{i}$ was prepared according to the general procedure with the following modifications: $25 \mathrm{~mol} \%$ catalyst $\left(\mathrm{CuCl}+\mathrm{PCy}_{3}\right) ; 50 \mathrm{~mol} \%$ $\mathrm{NaOt}$-Bu, RT, $20 \mathrm{~h}$. Crude allylboronic ester $\mathbf{2 i}$ was characterized by ${ }^{1} \mathrm{H}$ and ${ }^{19} \mathrm{~F}$ NMR spectroscopy after extraction with ethyl acetate. Only diagnostic resonances are reported in the ${ }^{1} \mathrm{H}$ NMR spectrum.

${ }^{1} \mathbf{H}$ NMR (600 MHz, $\left.\mathrm{CDCl}_{3}\right) \delta 5.21(\mathrm{dt}, J=17.3,3.7 \mathrm{~Hz}$, minor $E$-isomer), 4.97 (dt, $J=38.4$, $7.8 \mathrm{~Hz}$, major Z-isomer).

${ }^{19} \mathbf{F}$ NMR $\left(565 \mathrm{MHz}, \mathrm{CDCl}_{3}\right) \delta-121.9(\mathrm{~d}, J=16.9 \mathrm{~Hz}$, minor $E$-isomer $),-125.7(\mathrm{~d}, J=38.4 \mathrm{~Hz}$, major Z-isomer).

(Z)-2-fluoro-1-(naphthalen-2-yl)-4-(4,4,5,5-tetramethyl-1,3,2-dioxaborolan-2-yl)but-2-en-1ol (2j)

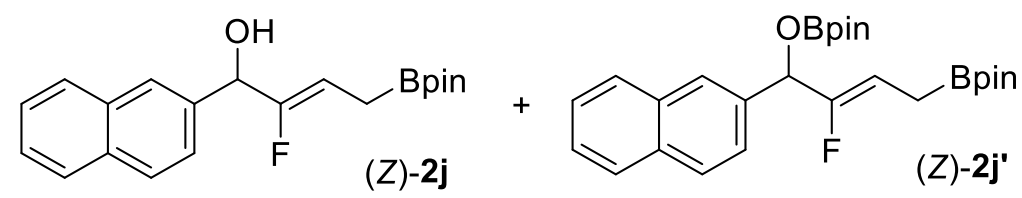

Prepared according to the general procedure with the following modifications: $25 \mathrm{~mol} \%$ $\mathrm{Cu}$ (xantphos)Cl, $50 \mathrm{~mol} \% \mathrm{NaO} t$-Bu RT, $20 \mathrm{~h}$. Crude allylboronic ester $\mathbf{2 j} \mathbf{j}+\mathbf{2 j}$ ' was characterized by ${ }^{1} \mathrm{H}$ and ${ }^{19} \mathrm{~F}$ NMR spectroscopy after extraction with ethyl acetate. The two species have similar 


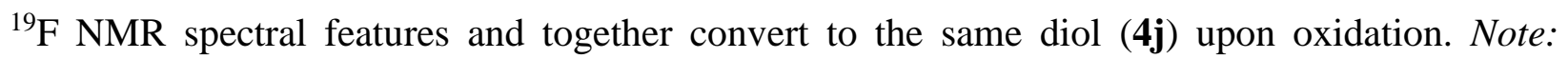
Reactions conducted under standard conditions (with catalytic $\mathrm{CuCl}+\mathrm{PCy}_{3}$ ) produce product $\mathbf{2} \mathbf{j}$ $+\mathbf{2} \mathbf{j}$ ' as a mixture of $Z$ and $E$ isomers in an 88:12 $Z: E$ ratio. Reactions conducted with $\mathrm{Cu}$ (xantphos) $\mathrm{Cl}$ provided product $\mathbf{2} \mathbf{j}+\mathbf{2} \mathbf{j}$ ' each in $>95: 5$ selectivity for the $Z$ isomer (The $Z$ isomers are not observed in crude ${ }^{19} \mathrm{~F}$ NMR spectra but the corresponding diol formed after oxidation was isolated as a 98:2 mixture of $Z$ and $E$ isomers.) Only diagnostic resonances are reported in the ${ }^{1} \mathrm{H}$ NMR spectrum below.

${ }^{1} \mathbf{H}$ NMR $\left(600 \mathrm{MHz}, \mathrm{CDCl}_{3}\right) \delta$ major Z-isomers: $5.75(\mathrm{~d}, J=11.7 \mathrm{~Hz} 1 \mathrm{H}), 5.41(\mathrm{~d}, J=14.4 \mathrm{~Hz}$, $1 \mathrm{H}), 5.14(\mathrm{dt}, J=36.7,7.9 \mathrm{~Hz}, 1 \mathrm{H}), 5.07(\mathrm{dt}, J=36.0,7.9 \mathrm{~Hz}, 1 \mathrm{H})$.

${ }^{19}$ F NMR $\left(565 \mathrm{MHz}, \mathrm{CDCl}_{3}\right) \delta$ major $Z$-isomers: $-123.0(\mathrm{dd}, J=36.0,11.9 \mathrm{~Hz}),-123.8(\mathrm{dd}, J=$ $36.8,14.2 \mathrm{~Hz}$ ). minor $E$-isomers (only visible in crude reactions conducted with catalytic $\left.\mathrm{CuCl}+\mathrm{PCy}_{3}\right):-121.9(\mathrm{dd}, J=25.6,20.8 \mathrm{~Hz}),-122.7(\mathrm{dd}, J=26.2,20.4 \mathrm{~Hz})$.

\section{(Z)-2-(3,4,4,5,5,6,6,7,7,8,8,8-dodecafluorooct-2-en-1-yl)-4,4,5,5-tetramethyl-1,3,2-}

dioxaborolane $(2 \mathrm{k})$

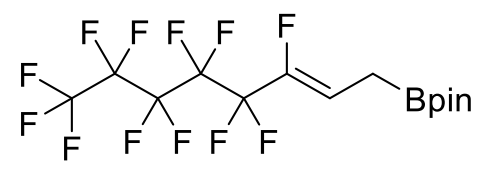

Prepared according to the general procedure. Crude allylboronic ester $\mathbf{2 k}$ was characterized by ${ }^{1} \mathrm{H}$ and ${ }^{19} \mathrm{~F}$ NMR spectroscopy. Diagnostic resonances in the ${ }^{1} \mathrm{H}$ NMR spectrum are reported only.

${ }^{1} \mathbf{H}$ NMR $\left(600 \mathrm{MHz}, \mathrm{CDCl}_{3}\right) \delta 5.71(\mathrm{dt}, J=33.5,8.4 \mathrm{~Hz}, 1 \mathrm{H})$.

${ }^{19}$ F NMR $\left(565 \mathrm{MHz}, \mathrm{CDCl}_{3}\right) \delta-80.9(\mathrm{t}, J=10.1 \mathrm{~Hz}, 3 \mathrm{~F}),-117.3(\mathrm{q}, J=13.7 \mathrm{~Hz}, 2 \mathrm{~F}),-122.9--$ $123.1(\mathrm{~m}, 2 \mathrm{~F}),-123.4--123.6(\mathrm{~m}, 2 \mathrm{~F}),-126.2--126.3(\mathrm{~m}, 2 \mathrm{~F}),-134.1--134.3(\mathrm{~m}, 1 \mathrm{~F})$. 


\section{Characterization of Products}

\section{(Z)-3-fluoro-3-(naphthalen-2-yl)prop-2-en-1-ol (4a)}<smiles>OC/C=C(\F)c1ccc2ccccc2c1</smiles>

The title compound was prepared according to the general procedure for the defluorinative borylation of 3-substituted 3,3-difluoropropenes on a $0.200 \mathrm{mmol}$ scale. The yield of the corresponding boronic ester was determined to be $91 \%$ by ${ }^{19} \mathrm{~F}$ NMR analysis of the crude product with 99:1 Z:E selectivity. Oxidation conducted according to the general procedure and column chromatography (20/80 ethyl acetate/hexanes) of the crude product gave allylic alcohol $\mathbf{4 a}$ as a white solid (32.8 mg, $0.162 \mathrm{mmol}, 81 \%)$.

m.p. $86.5-88.0^{\circ} \mathrm{C}$

${ }^{1} \mathbf{H}$ NMR $\left(600 \mathrm{MHz} \mathrm{CDCl}_{3}\right) \delta 8.02(\mathrm{~s}, 1 \mathrm{H}), 7.88-7.78(\mathrm{~m}, 3 \mathrm{H}), 7.58(\mathrm{dt}, J=8.7,1.4 \mathrm{~Hz}, 1 \mathrm{H})$, $7.54-7.48$ (m, 2H), 5.79 (dt, $J=36.6,7.1 \mathrm{~Hz}, 1 \mathrm{H}), 4.51$ (dd, $J=7.1,2.0 \mathrm{~Hz}, 2 \mathrm{H}), 1.71$ (br s, $1 \mathrm{H})$. ${ }^{13} \mathrm{C}$ NMR $\left(151 \mathrm{MHz}, \mathrm{CDCl}_{3}\right) \delta 158.2(\mathrm{~d}, J=251.0 \mathrm{~Hz}), 133.7,133.1,129.0(\mathrm{~d}, J=27.8 \mathrm{~Hz})$, 128.7, 128.5 (d, $J=2.4 \mathrm{~Hz}), 127.8,127.0,126.8,124.0$ (d, $J=7.6 \mathrm{~Hz}), 121.9$ (d, $J=6.7 \mathrm{~Hz}), 105.5$ $(\mathrm{d}, J=15.4 \mathrm{~Hz}), 56.3(\mathrm{~d}, J=7.7 \mathrm{~Hz})$.

${ }^{19}$ F NMR $\left(376 \mathrm{MHz}, \mathrm{CDCl}_{3}\right) \delta-117.4(\mathrm{~d}, J=36.7 \mathrm{~Hz})$.

HRMS (EI): $m / z$ for $\mathrm{C}_{13} \mathrm{H}_{11} \mathrm{FO}^{+}[\mathrm{M}]^{+}$calcd.: 202.0794, found: 202.0796.

\section{(Z)-3-fluoro-3-phenylprop-2-en-1-ol (4b)}<smiles>OC/C=C(\F)c1ccccc1</smiles>

The title compound was prepared according to the general procedure for the defluorinative borylation of 3-substituted 3,3-difluoropropenes on a $0.200 \mathrm{mmol}$ scale. The yield of the corresponding boronic ester was determined to be $97 \%$ by ${ }^{19} \mathrm{~F}$ NMR analysis of the crude product with 98:2 Z:E selectivity. Oxidation according to the general procedure and column chromatography (20/80 ethyl acetate/hexanes) of the crude product gave allylic alcohol $\mathbf{4 b}$ as a clear oil (28.1 mg, $0.185 \mathrm{mmol}, 92 \%)$.

${ }^{1} \mathbf{H}$ NMR (600 MHz, $\left.\mathrm{CD}_{2} \mathrm{Cl}_{2}\right) \delta 7.57-7.52(\mathrm{~m}, 2 \mathrm{H}), 7.42-7.35(\mathrm{~m}, 3 \mathrm{H}), 5.68(\mathrm{dt}, J=37.0,7.0$ $\mathrm{Hz}, 1 \mathrm{H}), 4.41$ (dd, $J=7.0,2.2 \mathrm{~Hz}, 2 \mathrm{H}), 1.75$ (br s, 1H). 
${ }^{13}$ C NMR (151 MHz, $\left.\mathrm{CD}_{2} \mathrm{Cl}_{2}\right) \delta 157.9(\mathrm{~d}, J=250.2 \mathrm{~Hz}), 131.9(\mathrm{~d}, J=28.7 \mathrm{~Hz}), 129.3,128.6(\mathrm{~d}$, $J=2.1 \mathrm{~Hz}), 124.4(\mathrm{~d}, J=7.2 \mathrm{~Hz}), 105.3(\mathrm{~d}, J=15.3 \mathrm{~Hz}), 55.9(\mathrm{~d}, J=7.7 \mathrm{~Hz})$.

${ }^{19}$ F NMR $\left(565 \mathrm{MHz}, \mathrm{CD}_{2} \mathrm{Cl}_{2}\right) \delta-118.3(\mathrm{~d}, J=37.0 \mathrm{~Hz})$.

NMR spectra are consistent with the literature. ${ }^{4}$

(Z)-3-(4-(tert-butyl)phenyl)-3-fluoroprop-2-en-1-ol (4c)<smiles>CC(C)(C)c1ccc(/C(F)=C/CO)cc1</smiles>

The title compound was prepared according to the general procedure for the defluorinative borylation of 3-substituted 3,3-difluoropropenes on a $0.200 \mathrm{mmol}$ scale. The yield of the corresponding boronic ester was determined to be $98 \%$ with $98: 2 \mathrm{Z}: E$ selectivity by ${ }^{19} \mathrm{~F}$ NMR analysis of the crude product. Oxidation according to the general procedure and column chromatography (20/80 ethyl acetate/hexanes) of the crude product gave allylic alcohol $\mathbf{4 c}$ as a white solid (39.9 mg, $0.192 \mathrm{mmol}, 96 \%)$.

m.p. $59.0-60.0^{\circ} \mathrm{C}$

${ }^{1}$ H NMR (600 MHz, C6 $\left.\mathrm{D}_{6}\right) \delta 7.41(\mathrm{~d}, J=8.4 \mathrm{~Hz}, 2 \mathrm{H}), 7.18(\mathrm{~d}, J=8.1 \mathrm{~Hz}, 2 \mathrm{H}), 5.40(\mathrm{dt}, J=37.3$, $7.0 \mathrm{~Hz}, 1 \mathrm{H}), 4.22(\mathrm{dd}, J=6.9,2.1 \mathrm{~Hz}, 2 \mathrm{H}), 1.16$ (s, 9H). Note: The OH proton was not observed. ${ }^{13} \mathrm{C}$ NMR $\left(151 \mathrm{MHz}, \mathrm{C}_{6} \mathrm{D}_{6}\right) \delta 158.0(\mathrm{~d}, J=249.3 \mathrm{~Hz}), 152.4,129.8(\mathrm{~d}, J=28.8 \mathrm{~Hz}), 125.8(\mathrm{~d}, J$ $=2.1 \mathrm{~Hz}), 124.6(\mathrm{~d}, J=7.1 \mathrm{~Hz}), 105.6(\mathrm{~d}, J=15.2 \mathrm{~Hz}), 56.2(\mathrm{~d}, J=7.5 \mathrm{~Hz}), 34.7,31.3$.

${ }^{19}$ F NMR (565 MHz, $\left.\mathrm{C}_{6} \mathrm{D}_{6}\right) \delta-118.0(\mathrm{~d}, J=37.2 \mathrm{~Hz})$.

HRMS (EI): $m / z$ for $\mathrm{C}_{13} \mathrm{H}_{17} \mathrm{FO}^{+}[\mathrm{M}]^{+}$calcd.: 208.1263, found: 208.1264.

\section{(Z)-3-fluoro-3-(4-(trifluoromethyl)phenyl)prop-2-en-1-ol (4e)}<smiles>OC/C=C(\F)c1ccc(C(F)(F)F)cc1</smiles>

The title compound was prepared according to the general procedure for the defluorinative borylation of 3-substituted 3,3-difluoropropenes on a $0.200 \mathrm{mmol}$ scale. The yield of the corresponding boronic ester was determined to be $89 \%$ with $99: 1 Z$ :E selectivity by ${ }^{19} \mathrm{~F}$ NMR analysis of the crude product. Oxidation according to the general procedure and column chromatography (20/80 ethyl acetate/hexanes) of the crude product gave allylic alcohol $4 \mathbf{e}$ as a clear oil (33.9 mg, $0.154 \mathrm{mmol}, 77 \%)$. 
${ }^{1} \mathbf{H}$ NMR $\left(600 \mathrm{MHz}, \mathrm{CDCl}_{3}\right) \delta 7.63(\mathrm{~s}, 4 \mathrm{H}), 5.77(\mathrm{dt}, J=36.3,7.0 \mathrm{~Hz}, 1 \mathrm{H}), 4.48(\mathrm{dd}, J=7.0,2.2$ $\mathrm{Hz}, 2 \mathrm{H}), 1.72$ (br s, 1H).

${ }^{13} \mathrm{C}$ NMR $\left(151 \mathrm{MHz}, \mathrm{CDCl}_{3}\right) \delta 156.7(\mathrm{~d}, J=251.1 \mathrm{~Hz}), 135.2(\mathrm{~d}, J=29.2 \mathrm{~Hz}), 131.3(\mathrm{q}, J=32.6$ Hz), $125.8-125.7(\mathrm{~m}), 124.8$ (d, $J=7.2 \mathrm{~Hz}), 124.0$ (q, $J=272.1 \mathrm{~Hz}), 107.4$ (d, $J=14.9 \mathrm{~Hz}), 56.2$ $(\mathrm{d}, J=7.4 \mathrm{~Hz})$.

${ }^{19}$ F NMR $\left(565 \mathrm{MHz}, \mathrm{CDCl}_{3}\right) \delta-62.9(3 \mathrm{~F}),-117.7$ (d, $\left.J=36.5 \mathrm{~Hz}, 1 \mathrm{~F}\right)$.

NMR spectra are consistent with the literature. ${ }^{4}$

(Z)-3-fluoro-3-(4-(hydroxymethyl)phenyl)prop-2-en-1-ol (4f)<smiles>OC/C=C(\F)c1ccc(CO)cc1</smiles>

The title compound was prepared according to the general procedure for the defluorinative borylation of 3-substituted 3,3-difluoropropenes on a $0.200 \mathrm{mmol}$ scale. The yield of the corresponding boronic ester was determined to be $92 \%$ with 98:2 Z:E selectivity by ${ }^{19} \mathrm{~F}$ NMR analysis of the crude product. Oxidation according to the general procedure and column chromatography (gradient from 20/80 to 50/50 ethyl acetate/hexanes) of the crude mixture gave allylic alcohol $\mathbf{4 f}$ as a white solid (27.7 $\mathrm{mg}, 0.152 \mathrm{mmol}, 76 \%)$.

m.p. $88.5-89.0{ }^{\circ} \mathrm{C}$

${ }^{1}$ H NMR (600 MHz, Acetone-d $\left.d_{6}\right) \delta .53(\mathrm{~d}, J=8.2 \mathrm{~Hz}, 2 \mathrm{H}), 7.40(\mathrm{~d}, J=8.0 \mathrm{~Hz}, 2 \mathrm{H}), 5.72(\mathrm{dt}, J$ $=38.1,6.9 \mathrm{~Hz}, 1 \mathrm{H}), 4.65(\mathrm{~d}, J=5.8 \mathrm{~Hz}, 2 \mathrm{H}), 4.34(\mathrm{ddd}, J=7.2,5.8,2.2 \mathrm{~Hz}, 2 \mathrm{H}), 4.27(\mathrm{t}, J=5.8$ $\mathrm{Hz}, 1 \mathrm{H}), 3.84(\mathrm{t}, J=5.7 \mathrm{~Hz}, 1 \mathrm{H})$.

${ }^{13}$ C NMR $\left(151 \mathrm{MHz}\right.$, Acetone- $\left.d_{6}\right) \delta 157.4(\mathrm{~d}, J=247.1 \mathrm{~Hz}), 144.6,131.4(\mathrm{~d}, J=28.8 \mathrm{~Hz}), 127.5$ $(\mathrm{d}, J=2.1 \mathrm{~Hz}), 124.8(\mathrm{~d}, J=7.1 \mathrm{~Hz}), 107.0(\mathrm{~d}, J=15.4 \mathrm{~Hz}), 64.2,55.7(\mathrm{~d}, J=7.8 \mathrm{~Hz})$.

${ }^{19}$ F NMR $\left(565 \mathrm{MHz}\right.$, Acetone- $\left.d_{6}\right) \delta-120.4(\mathrm{~d}, J=37.9 \mathrm{~Hz})$.

HRMS (EI): $m / z$ for $\mathrm{C}_{10} \mathrm{H}_{11} \mathrm{FO}_{2}{ }^{+}[\mathrm{M}]^{+}$calcd.: 182.0743, found: 182.0744 . 


\section{(Z)-3-(4-bromophenyl)-3-fluoroprop-2-en-1-ol (4g)}<smiles>OC/C=C(\F)c1ccc(Br)cc1</smiles>

The title compound was prepared according to the general procedure for the defluorinative borylation of 3-substituted 3,3-difluoropropenes on a $0.200 \mathrm{mmol}$ scale. The yield of the corresponding boronic ester was determined to be $99 \%$ with $99: 1 Z: E$ selectivity by ${ }^{19} \mathrm{~F}$ NMR analysis of the crude product. Oxidation according to the general procedure and column chromatography (20/80 ethyl acetate/hexanes) of the crude product gave allylic alcohol $\mathbf{4 g}$ was isolated as a pale yellow gum $(44.2 \mathrm{mg}, 0.191 \mathrm{mmol}, 96 \%)$.

Compound $\mathbf{4 g}$ is known. ${ }^{4}$

${ }^{1} \mathbf{H}$ NMR $\left(600 \mathrm{MHz}^{\mathrm{CDCl}}{ }_{3}\right) \delta 7.53(\mathrm{~d}, J=8.5 \mathrm{~Hz}, 2 \mathrm{H}), 7.41(\mathrm{~d}, J=8.6 \mathrm{~Hz}, 2 \mathrm{H}), 5.68(\mathrm{dt}, J=$ $36.4,7.1 \mathrm{~Hz}, 1 \mathrm{H}), 4.46$ (dd, $J=7.1,2.1 \mathrm{~Hz}, 2 \mathrm{H}), 1.68$ (br s, 1H).

${ }^{13}$ C NMR (151 MHz, $\left.\mathrm{CDCl}_{3}\right) \delta 157.3(\mathrm{~d}, J=251.0 \mathrm{~Hz}), 131.9(\mathrm{~d}, J=2.4 \mathrm{~Hz}), 130.8(\mathrm{~d}, J=29.3$

$\mathrm{Hz}), 126.1(\mathrm{~d}, J=7.2 \mathrm{~Hz}), 123.7,105.6(\mathrm{~d}, J=15.0 \mathrm{~Hz}), 56.2(\mathrm{~d}, J=7.7 \mathrm{~Hz})$.

${ }^{19}$ F NMR $\left(565 \mathrm{MHz}, \mathrm{CDCl}_{3}\right) \delta-117.4(\mathrm{~d}, J=36.4 \mathrm{~Hz})$.

The NMR spectra are consistent with the literature. ${ }^{4}$

\section{(Z)-3-(2,5-dimethylphenyl)-3-fluoroprop-2-en-1-ol (4h)}<smiles>Cc1ccc(C)c(/C(F)=C/CO)c1</smiles>

The title compound was prepared according to the general procedure for the defluorinative borylation of 3-substituted 3,3-difluoropropenes on a $0.200 \mathrm{mmol}$ scale. The yield of the corresponding boronic ester was determined to be $96 \%$ with 99:1 Z:E selectivity by ${ }^{19} \mathrm{~F}$ NMR analysis of the crude product. Oxidation according to the general procedure and column chromatography (20/80 ethyl acetate/hexanes) of the crude product gave allylic alcohol $\mathbf{4 h}$ as a clear oil (32.6 mg, $0.181 \mathrm{mmol}, 91 \%)$.

${ }^{1} \mathbf{H}$ NMR $\left(600 \mathrm{MHz}, \mathrm{CD}_{2} \mathrm{Cl}_{2}\right) \delta 7.20(\mathrm{~s}, 1 \mathrm{H}), 7.11(\mathrm{~s}, 2 \mathrm{H}), 5.28(\mathrm{dt}, J=36.1,6.9 \mathrm{~Hz}, 1 \mathrm{H}), 4.40$ (dd, $J=7.0,2.2 \mathrm{~Hz}, 2 \mathrm{H}), 2.36(\mathrm{~d}, J=3.2 \mathrm{~Hz}, 3 \mathrm{H}), 2.32$ (s, 3H), 1.76 (br s, 1H) 
${ }^{13}$ C NMR (151 MHz, $\left.\mathrm{CD}_{2} \mathrm{Cl}_{2}\right) \delta 159.4(\mathrm{~d}, J=254.9 \mathrm{~Hz}), 135.4,133.5,132.0(\mathrm{~d}, J=25.6 \mathrm{~Hz})$, 130.7, 130.3, $129.4(\mathrm{~d}, J=5.0 \mathrm{~Hz}), 109.2(\mathrm{~d}, J=15.9 \mathrm{~Hz}), 56.0(\mathrm{~d}, J=6.8 \mathrm{~Hz}), 20.6,19.9(\mathrm{~d}, J=$ $3.3 \mathrm{~Hz})$.

${ }^{19}$ F NMR $\left(565 \mathrm{MHz}, \mathrm{CD}_{2} \mathrm{Cl}_{2}\right) \delta-101.2(\mathrm{~d}, J=36.2 \mathrm{~Hz})$.

HRMS (EI): $m / z$ for $\mathrm{C}_{11} \mathrm{H}_{13} \mathrm{FO}^{+}[\mathrm{M}]^{+}$calcd.: 180.0950 , found: 180.0951 .

\section{(Z)-1-(1-fluoro-3-hydroxyprop-1-en-1-yl)cyclohexan-1-ol (4i)}<smiles>OC/C=C(\F)C1(O)CCCC1</smiles>

The title compound was prepared according to the general procedure for the defluorinative borylation of 3-substituted 3,3-difluoropropenes on a $0.200 \mathrm{mmol}$ scale with the following modifications: $25 \mathrm{~mol} \% \mathrm{CuCl}+\mathrm{PCy}_{3}, 50 \mathrm{~mol} \% \mathrm{NaO} t$-Bu RT, $20 \mathrm{~h}$. The boronic ester intermediate was extracted with ethyl acetate prior to analysis by NMR spectroscopy. The yield of the corresponding boronic ester was determined to be $89 \%$ with $94: 6 \mathrm{Z}: E$ selectivity by ${ }^{19} \mathrm{~F}$ NMR analysis of the crude product. Oxidation according to the general procedure and column chromatography (20/80 to 60/40 ethyl acetate/hexanes) of the crude product gave the pure $Z$ isomer of allylic alcohol $4 \mathbf{i}$ as a white powder (27.5 $\mathrm{mg}, 0.158 \mathrm{mmol}, 79 \%)$.

m.p. $69.0-70.0^{\circ} \mathrm{C}$

${ }^{1}$ H NMR $\left(600 \mathrm{MHz}, \mathrm{CD}_{3} \mathrm{CN}\right) \delta 5.13(\mathrm{dt}, J=38.4,7.0 \mathrm{~Hz}, 1 \mathrm{H}), 4.12(\mathrm{~d}, J=7.0 \mathrm{~Hz}, 2 \mathrm{H}), 2.97$ (br s, 1H), 2.76 (br s, 1H), $1.71-1.49(\mathrm{~m}, 9 \mathrm{H}), 1.33-1.22(\mathrm{~m}, 1 \mathrm{H})$.

${ }^{13} \mathrm{C}$ NMR $\left(151 \mathrm{MHz}, \mathrm{CD}_{3} \mathrm{CN}\right) \delta 165.7(\mathrm{~d}, J=261.2 \mathrm{~Hz}), 104.7(\mathrm{~d}, J=12.9 \mathrm{~Hz}), 71.5(\mathrm{~d}, J=27.1$ $\mathrm{Hz}), 55.3(\mathrm{~d}, J=8.7 \mathrm{~Hz}), 35.2,26.1,22.2$.

${ }^{19}$ F NMR $\left(565 \mathrm{MHz}, \mathrm{CD}_{3} \mathrm{CN}\right) \delta-123.2(\mathrm{~d}, J=38.5 \mathrm{~Hz})$.

HRMS (ESI negative): $m / z$ for $\mathrm{C}_{9} \mathrm{H}_{14} \mathrm{FO}_{2}{ }^{-}[\mathrm{M}-\mathrm{H}]^{-}$calcd.: 173.0983, found: 173.0985.

\section{(Z)-2-fluoro-1-(naphthalen-2-yl)but-2-ene-1,4-diol (4j)}<smiles>OC/C=C(\F)C(O)c1ccc2ccccc2c1</smiles>

The title compound was prepared according to the general procedure for the defluorinative borylation of 3-substituted 3,3-difluoropropenes on a $0.200 \mathrm{mmol}$ scale with the following modifications: $25 \mathrm{~mol} \% \mathrm{Cu}$ (xantphos)Cl, $50 \mathrm{~mol} \% \mathrm{NaOt}$-Bu, RT, $20 \mathrm{~h}$. The boronic ester intermediate was extracted with ethyl acetate prior to analysis by NMR spectroscopy. The yield of 
the corresponding boronic ester was determined to be $89 \%$ with $>95: 5 Z: E$ selectivity by ${ }^{19} \mathrm{~F}$ NMR analysis of the crude product. Oxidation according to the general procedure and column chromatography (20/80 to 60/40 ethyl acetate/hexanes) of the crude product gave allylic alcohol $\mathbf{4 j}$ as a white solid as a 98:2 mixture of $Z$ and $E$ isomers (36.4 $\mathrm{mg}, 0.157 \mathrm{mmol}, 78 \%$ ).

m.p. $108.5-110.0^{\circ} \mathrm{C}$

${ }^{1} \mathbf{H}$ NMR $\left(600 \mathrm{MHz}, \mathrm{CD}_{3} \mathrm{CN}\right) \delta 7.95-7.86(\mathrm{~m}, 4 \mathrm{H}), 7.57-7.47(\mathrm{~m}, 3 \mathrm{H}), 5.36(\mathrm{dd}, J=13.2,4.7$ $\mathrm{Hz}, 1 \mathrm{H}), 5.25(\mathrm{dt}, J=37.3,7.0 \mathrm{~Hz}, 1 \mathrm{H}), 4.14(\mathrm{ddd}, J=7.4,5.5,2.0 \mathrm{~Hz}, 2 \mathrm{H}), 4.06(\mathrm{~d}, J=4.9 \mathrm{~Hz}$, $1 \mathrm{H}), 2.84(\mathrm{t}, J=5.7 \mathrm{~Hz}, 1 \mathrm{H})$.

Note: Minor (2\%) impurities corresponding to the $\mathrm{E}$ isomer were observed in the ${ }^{1} \mathrm{H}$ NMR spectrum. Diagnostic resonances: $5.81(\mathrm{dd}, J=26.1,4.6 \mathrm{~Hz}, 1 \mathrm{H}), 5.45(\mathrm{dt}, J=21.2,7.6 \mathrm{~Hz}, 1 \mathrm{H})$. ${ }^{13} \mathrm{C}$ NMR $\left(151 \mathrm{MHz}, \mathrm{CD}_{3} \mathrm{CN}\right) \delta 161.0(\mathrm{~d}, J=259.0 \mathrm{~Hz}), 138.9,134.1,134.1,129.0,128.9,128.6$, 127.3, 127.2, 126.5, 125.7, $108.0(\mathrm{~d}, J=11.5 \mathrm{~Hz}), 72.5$ (d, $J=31.5 \mathrm{~Hz}), 55.1(\mathrm{~d}, J=7.2 \mathrm{~Hz})$.

${ }^{19}$ F NMR $\left(565 \mathrm{MHz}, \mathrm{CD}_{3} \mathrm{CN}\right) \delta-121.20(\mathrm{dd}, J=37.1,13.2 \mathrm{~Hz}, 1 \mathrm{~F})$ Note: A minor (2\%) impurity of the corresponding $E$-isomer was also observed in the ${ }^{19} \mathrm{~F}$ NMR spectrum: $-119.47(\mathrm{t}, J=23.6$ $\mathrm{Hz})$.

HRMS (ESI negative): $m / z$ for $\mathrm{C}_{14} \mathrm{H}_{12} \mathrm{FO}_{2}{ }^{-}[\mathrm{M}-\mathrm{H}]^{-}$calcd.: 231.0827, found: 231.0830 .

\section{(Z)-3,4,4,5,5,6,6,7,7,8,8,8-dodecafluorooct-2-en-1-ol (4k)}

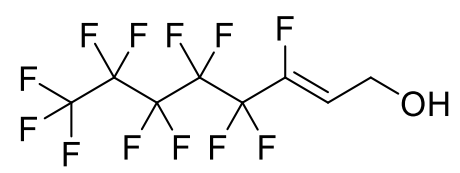

The title compound was prepared according to the general procedure for the defluorinative borylation of 3-substituted 3,3-difluoropropenes on a $0.200 \mathrm{mmol}$ scale. The yield of the corresponding boronic ester was determined to be $98 \%$ with $>98: 2 Z$ :E selectivity by ${ }^{19} \mathrm{~F}$ NMR analysis of the crude product (Although no diagnostic peaks for the corresponding $E$ isomer could be identified, all impurities were present in $<2 \%$ yield in the crude ${ }^{19} \mathrm{~F}$ NMR spectrum). After oxidation according to the general procedure and column chromatography (gradient from 5/95 to 20/80 ethyl acetate/hexanes) of the crude reaction product, allylic alcohol $\mathbf{4} \mathbf{i}$ was isolated under weak vacuum (15 torr) as a clear oil (46.0 mg, $0.134 \mathrm{mmol}, 67 \%)$. After subjecting the sample to high vacuum ( $\sim .5$ torr, 10 minutes) the residual solvent was removed, but the isolated yield was significantly lower due to the volatility of the product (16.3 $\mathrm{mg}, 0.0474 \mathrm{mmol}, 24 \%$ ). 
${ }^{1} \mathbf{H}$ NMR $\left(600 \mathrm{MHz}, \mathrm{CD}_{2} \mathrm{Cl}_{2}\right) \delta 5.86(\mathrm{dt}, J=34.1,6.5 \mathrm{~Hz}, 1 \mathrm{H}), 4.44-4.38(\mathrm{~m}, 2 \mathrm{H}), 1.79(\mathrm{~s}, 1 \mathrm{H})$. ${ }^{13}$ C NMR $\left(151 \mathrm{MHz}, \mathrm{CD}_{2} \mathrm{Cl}_{2}\right) \delta 145.89(\mathrm{dt}, J=261.5,29.3 \mathrm{~Hz}), 115.95(\mathrm{dt}, J=7.8,4.2 \mathrm{~Hz}), 55.06$ $(\mathrm{d}, J=5.1 \mathrm{~Hz})$ (all other signals were split by coupling to several fluorine atoms and could not be observed).

${ }^{19}$ F NMR $\left(565 \mathrm{MHz}, \mathrm{CD}_{2} \mathrm{Cl}_{2}\right) \delta-81.2(\mathrm{t}, J=10.2 \mathrm{~Hz}, 3 \mathrm{~F}),-118.1$ (q, $\left.J=13.8 \mathrm{~Hz}, 2 \mathrm{~F}\right),-123.1-$ $123.2(\mathrm{~m}, 2 \mathrm{~F}),-123.4--123.6(\mathrm{~m}, 2 \mathrm{~F}),-126.4--126.6(\mathrm{~m}, 2 \mathrm{~F}),-129.3--129.5(\mathrm{~m}, 1 \mathrm{~F})$.

HRMS (EI): $m / z$ for $\mathrm{C}_{8} \mathrm{H}_{4} \mathrm{~F}_{12} \mathrm{O}^{+}[\mathrm{M}]^{+}$calcd.: 344.0071 , found: 344.0029 .

Note: The error of the observed mass and predicted mass is $12 \mathrm{ppm}$. A second attempt to measure the HRMS was unsuccessful, as it is difficult to observe the molecular ion of compound $\mathbf{4 k}$ by EI. 


\section{Derivatization of Defluorinative Borylation Products}

\section{rac-(1R,2S)-2-fluoro-2-(naphthalen-2-yl)-1-phenylbut-3-en-1-ol (6a)}<smiles>C=CC(F)(F)C(O)c1ccccc1</smiles>

The following procedure was adapted from the literature. ${ }^{5}$ In a nitrogen-filled glovebox, a $15 \mathrm{~mL}$ Schlenk flask with a single opening sealed with a Teflon plug was equipped with a stir bar was charged with 3-fluoro allyl boronic ester $\mathbf{2 a}$ (45.7 $\mathrm{mg}$ of a 1.33:1 mole ratio of boronic ester $2 \mathbf{a}$ to $\mathrm{B}_{2}$ pin 2 , corresponding to $0.0900 \mathrm{mmol}$ of $\left.\mathbf{2 a}\right)$ and tetrahydrofuran $(0.90 \mathrm{~mL})$. The flask was sealed with the Teflon plug, equipped with a rubber septum, and then removed from the glove box. The reaction mixture was and cooled to $-78{ }^{\circ} \mathrm{C}$ with an acetone dry ice bath. Under $\mathrm{N}_{2}$, a solution of $n$-butyllithium in hexanes $(2.00$ equiv, $1.6 \mathrm{M}, 113 \mu \mathrm{L}, 0.180 \mathrm{mmol})$ was added dropwise to the solution, and the reaction mixture was allowed to stir at $-78{ }^{\circ} \mathrm{C}$ for 15 minutes. Trifluoroacetic anhydride (2.10 equiv, $39.7 \mu \mathrm{L}, 0.189 \mathrm{mmol})$ was added dropwise, and the reaction mixture was allowed to stir at $-78{ }^{\circ} \mathrm{C}$ for 30 minutes. Under $\mathrm{N}_{2}$, benzaldehyde $(0.27 \mathrm{mmol}, 27.5 \mu \mathrm{L})$ was added dropwise, and the reaction stirred at $-78^{\circ}{ }^{\circ} \mathrm{C}$ for 2 hours. The reaction was slowly warmed to room temperature and stirred overnight at the ambient temperature. After this time, the reaction was cooled to $0{ }^{\circ} \mathrm{C}$, quenched with $0.5 \mathrm{M} \mathrm{NaOH}(20 \mathrm{~mL})$, extracted with dichloromethane $(3 \times 15 \mathrm{~mL})$, and concentrated under vacuum. The crude material was subjected to purification by silica-gel column chromatography (gradient from 95/5 to 67/33 of hexanes/ethyl acetate) to provide pure homoallylic alcohol 6a as a pale yellow solid $(18.7 \mathrm{mg}, 0.0640 \mathrm{mmol}, 71 \%)$. The relative configuration was assigned based on a standard chair transition-state model and previous results. ${ }^{5}$ ${ }^{1}$ H NMR $\left(600 \mathrm{MHz}\right.$, Acetone- $\left.d_{6}\right) \delta 7.90-7.83(\mathrm{~m}, 4 \mathrm{H}), 7.58(\mathrm{dd}, J=8.6,1.8 \mathrm{~Hz}, 1 \mathrm{H}), 7.52$ - 7.47 (m, 2H), $7.31-7.26(\mathrm{~m}, 2 \mathrm{H}), 7.21-7.17(\mathrm{~m}, 3 \mathrm{H}), 6.68(\mathrm{ddd}, J=21.1,17.2,11.3 \mathrm{~Hz}, 1 \mathrm{H}), 5.32-$ $5.26(\mathrm{~m}, 2 \mathrm{H}), 5.19(\mathrm{dd}, J=14.3,5.1 \mathrm{~Hz}, 1 \mathrm{H}), 4.83(\mathrm{~d}, J=5.0 \mathrm{~Hz}, 1 \mathrm{H})$.

${ }^{13}$ C NMR (151 MHz, Acetone- $\left.d_{6}\right) \delta 140.9,139.5(\mathrm{~d}, J=22.1 \mathrm{~Hz}), 137.7$ (d, $\left.J=19.7 \mathrm{~Hz}\right), 133.8$, 133.7, 129.1, 129.1, 128.3, 128.2, 128.1, 128.0, 127.0, 127.0, 126.0 (d, $J=9.6 \mathrm{~Hz}), 125.0$ (d, $J=$ $8.0 \mathrm{~Hz}), 116.1(\mathrm{~d}, J=12.3 \mathrm{~Hz}), 99.7$ (d, $J=184.0 \mathrm{~Hz}), 79.1$ (d, $J=27.0 \mathrm{~Hz})$.

${ }^{19}$ F NMR $\left(565 \mathrm{MHz}\right.$, Acetone- $\left.d_{6}\right) \delta-165.1(\mathrm{t}, J=17.6 \mathrm{~Hz})$.

HRMS (EI): $m / z$ for $\mathrm{C}_{20} \mathrm{H}_{17} \mathrm{FO}^{+}[\mathrm{M}]^{+}$calcd.: 292.1263, found: 292.1262. 


\section{Potassium (Z)-trifluoro(3-fluoro-3-(naphthalen-2-yl)allyl)borate (5a)}<smiles>FC(=CCBr)c1ccc2ccccc2c1</smiles>

A $20 \mathrm{~mL}$ polyethylene vial equipped with a magnetic stir bar was charged with 3-fluoro allyl boronic ester $\mathbf{2 a}$ (30.2 $\mathrm{mg}$ of a 1.33:1 mole ratio of boronic ester $\mathbf{2 a}$ and $\mathrm{B}_{2}$ pin 2 , corresponding to $0.0600 \mathrm{mmol}$ of $\mathbf{2 a})$ and $\mathrm{KHF}_{2}(29.8 \mathrm{mg}, 6.35$ equiv, $0.381 \mathrm{mmol})$, and $670 \mu \mathrm{L}$ of tetrahydrofuran and $670 \mu \mathrm{L}$ of $\mathrm{H}_{2} \mathrm{O}$ were added. The resulting suspension was then stirred for 1 hour at room temperature. The volatile materials were then evaporated under vacuum to provide a white powdery residue. Acetone $(3 \mathrm{~mL})$ was added to the resulting white solid, and the supernatant was filtered. The insoluble material was then washed with acetone $(3 \times 3 \mathrm{~mL})$. The combined filtrate was dried under vacuum, and the resulting white powder was washed with diethyl ether $(3 \times 3$ $\mathrm{mL}$ ), which was again dried under vacuum to yield pure trifluoroborate 5a as a white powder (16.6 $\mathrm{mg}, 0.0533 \mathrm{mmol}, 89 \%)$.

m.p. $>250{ }^{\circ} \mathrm{C}$

${ }^{1}$ H NMR (600 MHz, Acetone- $\left.d_{6}\right) \delta 7.90-7.80(\mathrm{~m}, 4 \mathrm{H}), 7.62(\mathrm{dt}, J=8.7,1.6 \mathrm{~Hz}, 1 \mathrm{H}), 7.47$ (ddd, $J=8.2,6.8,1.4 \mathrm{~Hz}, 1 \mathrm{H}), 7.43(\mathrm{ddd}, J=8.1,6.8,1.4 \mathrm{~Hz}, 1 \mathrm{H}), 5.88(\mathrm{dt}, J=40.1,8.6 \mathrm{~Hz}, 1 \mathrm{H}), 1.32$ (br s, 2H).

${ }^{13}$ C NMR (151 MHz, Acetone- $\left.d_{6}\right) \delta 154.3(\mathrm{~d}, J=235.2 \mathrm{~Hz}), 134.5,133.4,133.0(\mathrm{~d}, J=29.7 \mathrm{~Hz})$, $128.9,128.6(\mathrm{~d}, J=2.9 \mathrm{~Hz}), 128.4,127.1,126.4,122.6(\mathrm{~d}, J=6.5 \mathrm{~Hz}), 121.3(\mathrm{~d}, J=7.1 \mathrm{~Hz}), 113.1$ (d, $J=19.4 \mathrm{~Hz}$ ), 18.4 (br s). The ${ }^{13} \mathrm{C} \mathrm{NMR}$ resonance at $18.4 \mathrm{ppm}$ has low intensity due to quadrupolar broadening.

${ }^{19}$ F NMR $\left(565 \mathrm{MHz}\right.$, Acetone- $\left.d_{6}\right) \delta-130.5(\mathrm{~d}, J=40.0 \mathrm{~Hz}, 1 \mathrm{~F}),-140.2--140.7$ (m, 3F). HRMS (ESI negative): $\mathrm{m} / z$ for $\mathrm{C}_{13} \mathrm{H}_{10}{ }^{11} \mathrm{BF}_{4}^{-}$[M-Na] ${ }^{-}$calcd.: 253.0817, found: 253.0818 . 


\section{DEFLUORINATIVE SILYLATION OF 3-SUBSTITUTED 3,3-DIFLUOROPROPENES}

\section{(Z)-(3-fluoro-3-(naphthalen-2-yl)allyl)dimethyl(phenyl)silane (10a)}<smiles>C[Si](C/C=C(\F)c1ccc2ccccc2c1)(c1ccccc1)c1ccccc1</smiles>

In a nitrogen-filled glovebox, a $4 \mathrm{~mL}$ vial equipped with a magnetic stir bar was charged with $\mathrm{CuCl}$ (2.0 mg, $0.020 \mathrm{mmol}, 19 \mathrm{~mol} \%$ ), $\mathrm{PCy}_{3}(5.6 \mathrm{mg}, 0.020 \mathrm{mmol}, 19 \mathrm{~mol} \%), \mathrm{NaOt}$-Bu (3.9 mg, $0.041 \mathrm{mmol}, 38 \mathrm{~mol} \%), 2-(1,1$-difluoroallyl)naphthalene $1 \mathrm{a}(22.0 \mathrm{mg}, 0.108 \mathrm{mmol}, 1$ equiv), and THF $(500 \mu \mathrm{L})$. The resulting mixture was stirred at room temperature for five minutes. Then, neat pinB-SiMe $2 \mathrm{Ph}$ was added with stirring $(55.0 \mu \mathrm{L}, 52.9 \mathrm{mg}, 0.202 \mathrm{mmol}, 1.87$ equiv). The resulting suspension was stirred at room temperature for $24 \mathrm{~h}$. After this time, the reaction mixture was diluted with saturated $\mathrm{NH}_{4} \mathrm{Cl}(20 \mathrm{~mL})$, extracted with DCM (3 x $\left.20 \mathrm{~mL}\right)$, dried over sodium sulfate, and dried under vacuum. The resulting residue was subjected to silica-gel column chromatography (99/1 hexanes/ethyl acetate to $95 / 5$ hexanes/ethyl acetate) to provide allyl silane 10a as a white solid (33.9 mg, $0.106 \mathrm{mmol}, 98 \%)$.

Note: This reaction was also conducted in an analogous fashion on a $0.661 \mathrm{mmol}$ scale $(135 \mathrm{mg}$ of compound 1a) to provide allyl silane 10a in high yield and high Z:E selectivity (98:2 Z:E) (198.5 mg, $0.619 \mathrm{mmol}, 94 \%)$.

m.p. $75.0-76.0{ }^{\circ} \mathrm{C}$

${ }^{1} \mathbf{H}$ NMR $\left(600 \mathrm{MHz}, \mathrm{CDCl}_{3}\right) \delta 7.93(\mathrm{~s}, 1 \mathrm{H}), 7.85(\mathrm{~d}, J=7.8 \mathrm{~Hz}, 1 \mathrm{H}), 7.82(\mathrm{~d}, J=7.7 \mathrm{~Hz}, 1 \mathrm{H})$, $7.79(\mathrm{~d}, J=8.7 \mathrm{~Hz}, 1 \mathrm{H}), 7.62-7.58(\mathrm{~m}, 2 \mathrm{H}), 7.54-7.46(\mathrm{~m}, 3 \mathrm{H}), 7.43-7.38(\mathrm{~m}, 3 \mathrm{H}), 5.58(\mathrm{dt}$, $J=36.8,8.9 \mathrm{~Hz}, 1 \mathrm{H}), 2.00(\mathrm{dd}, J=8.9,1.5 \mathrm{~Hz}, 2 \mathrm{H}), 0.40(\mathrm{~s}, 6 \mathrm{H})$.

${ }^{13} \mathrm{C}$ NMR $\left(151 \mathrm{MHz}, \mathrm{CDCl}_{3}\right) \delta 156.0(\mathrm{~d}, J=242.8 \mathrm{~Hz}), 138.6,133.7,133.4,133.0,130.4(\mathrm{~d}, J=$ $28.5 \mathrm{~Hz}), 129.3,128.4,128.2(\mathrm{~d}, J=2.7 \mathrm{~Hz}), 128.0,127.7,126.6,126.3,122.1(\mathrm{~d}, J=7.1 \mathrm{~Hz})$, $121.7(\mathrm{~d}, J=6.5 \mathrm{~Hz}), 103.6(\mathrm{~d}, J=18.9 \mathrm{~Hz}), 14.6(\mathrm{~d}, J=4.1 \mathrm{~Hz}),-3.0$.

${ }^{19}$ F NMR $\left(565 \mathrm{MHz}, \mathrm{CDCl}_{3}\right) \delta-122.7(\mathrm{~d}, J=36.8 \mathrm{~Hz})$.

HRMS (EI): $m / z$ for $\mathrm{C}_{21} \mathrm{H}_{21} \mathrm{SiF}^{+}[\mathrm{M}]^{+}$calcd.: 320.1397 , found: 320.1398 . 


\section{REFERENCES}

1. Min, Q. Q.; Yin, Z. S.; Feng, Z.; Guo, W. H.; Zhang, X. G., Highly Selective gemDifluoroallylation of Organoborons with Bromodifluoromethylated Alkenes Catalyzed by Palladium. J. Am. Chem. Soc. 2014, 136, 1230-1233.

2. Yang, Z.-Y.; J. Burton, D., A facile preparation of gem-difluorohomoallylic alcohols[1]. Journal of Fluorine Chemistry 1989, 44, 339-343.

3. Butcher, T. W.; Yang, J. L.; Amberg, W. M.; Watkins, N. B.; Wilkinson, N. D.; Hartwig, J. F., Desymmetrization of difluoromethylene groups by $\mathrm{C}-\mathrm{F}$ bond activation. Nature 2020, 583, 548-553.

4. Kasten, K.; Slawin, A. M. Z.; Smith, A. D., Enantioselective Synthesis of $\beta$-Fluoro- $\beta$-aryl$\alpha$-aminopentenamides by Organocatalytic [2,3]-Sigmatropic Rearrangement. Org. Lett. 2017, 19, 5182-5185.

5. $\quad$ Akiyama, S.; Kubota, K.; Mikus, M. S.; Paioti, P. H. S.; Romiti, F.; Liu, Q.; Zhou, Y.; Hoveyda, A. H.; Ito, H., Catalytic Enantioselective Synthesis of Allylic Boronates Bearing a Trisubstituted Alkenyl Fluoride and Related Derivatives. Angew. Chem. Int. Ed. 2019, 58, 11998-12003. 

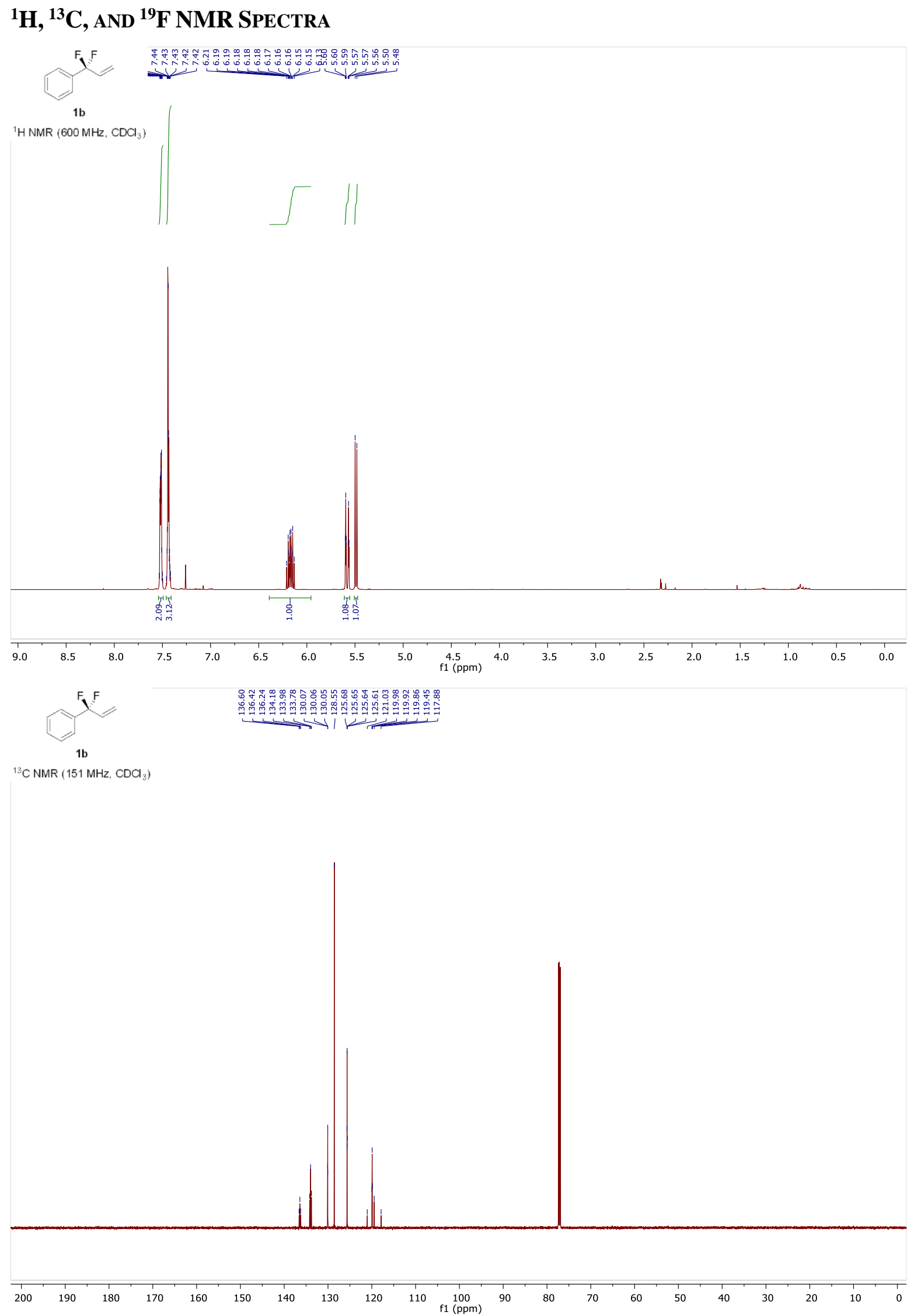


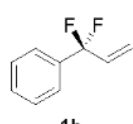

${ }^{19} \mathrm{~F} \mathrm{NMR}\left(565 \mathrm{MHz}, \mathrm{CDCl}_{3}\right)$

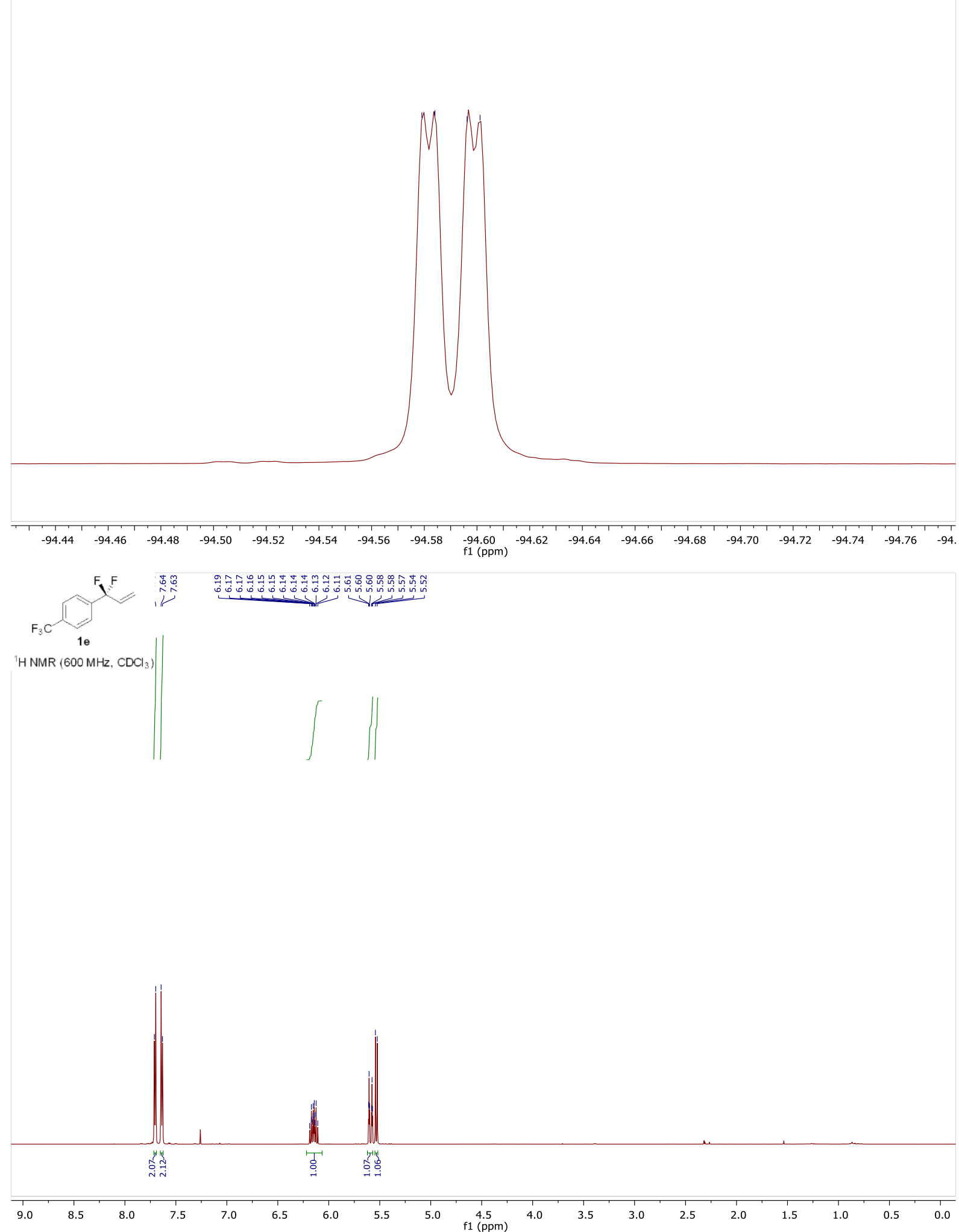



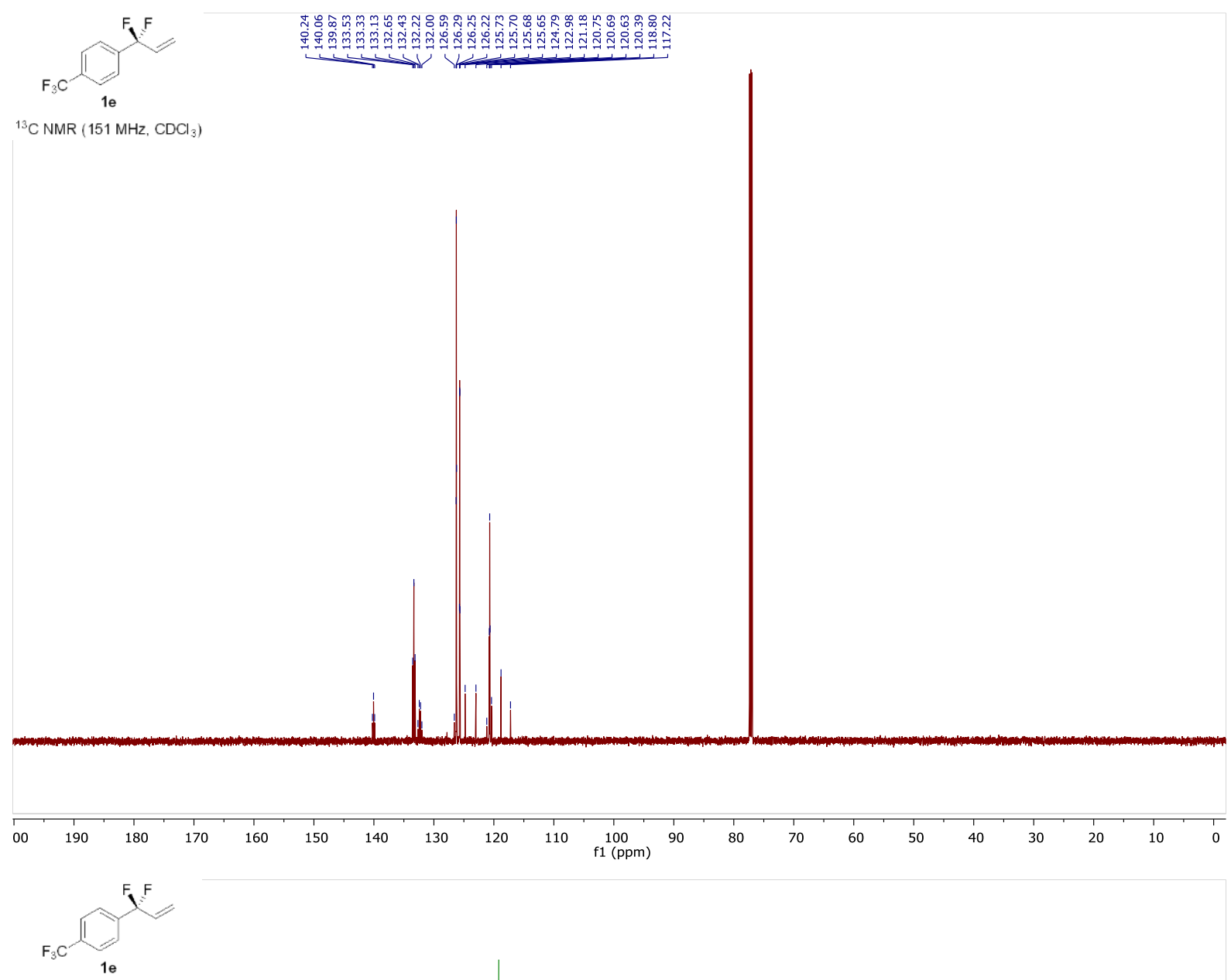

${ }^{19} \mathrm{~F} \mathrm{NMR}\left(565 \mathrm{MHz}, \mathrm{CDCl}_{3}\right)$

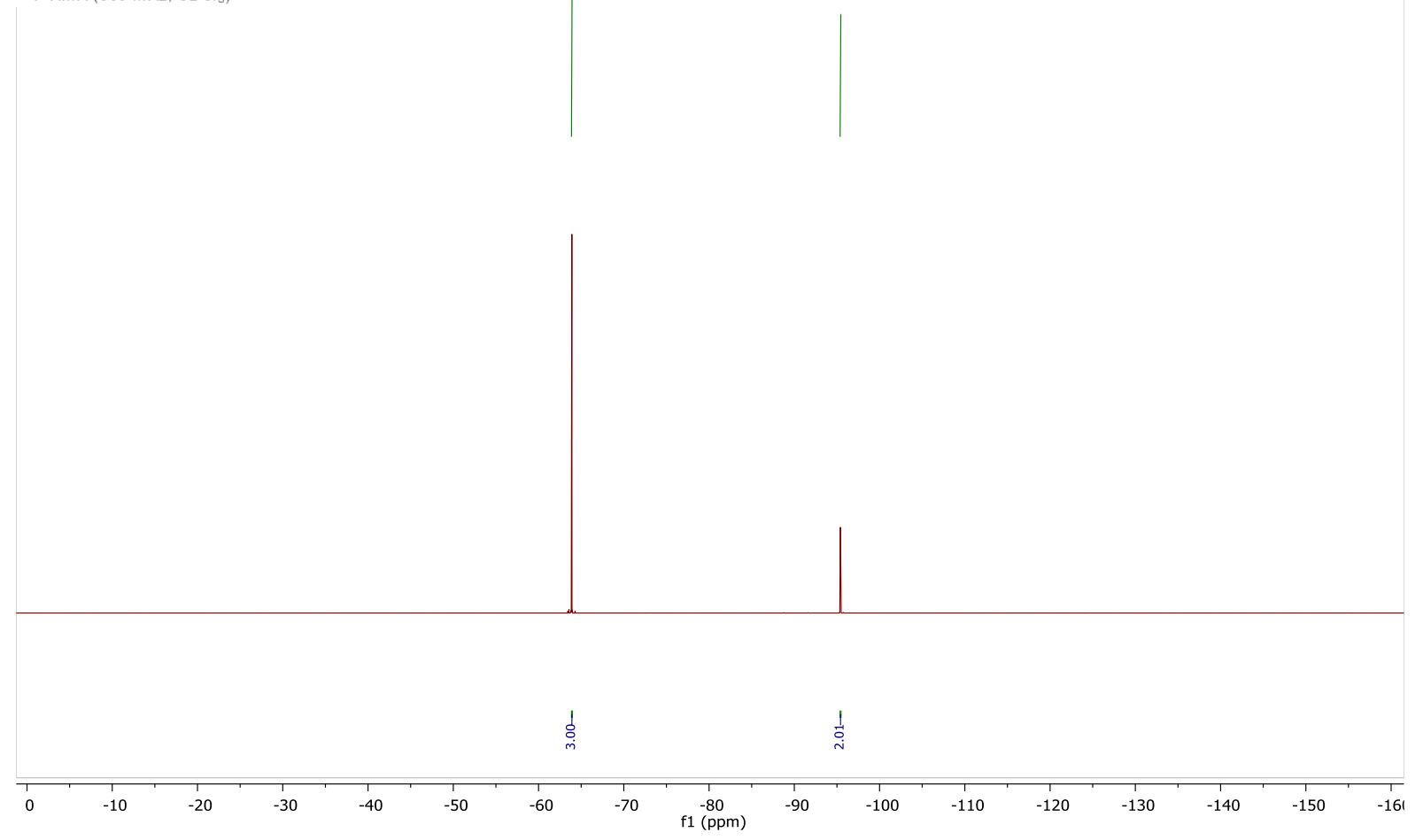



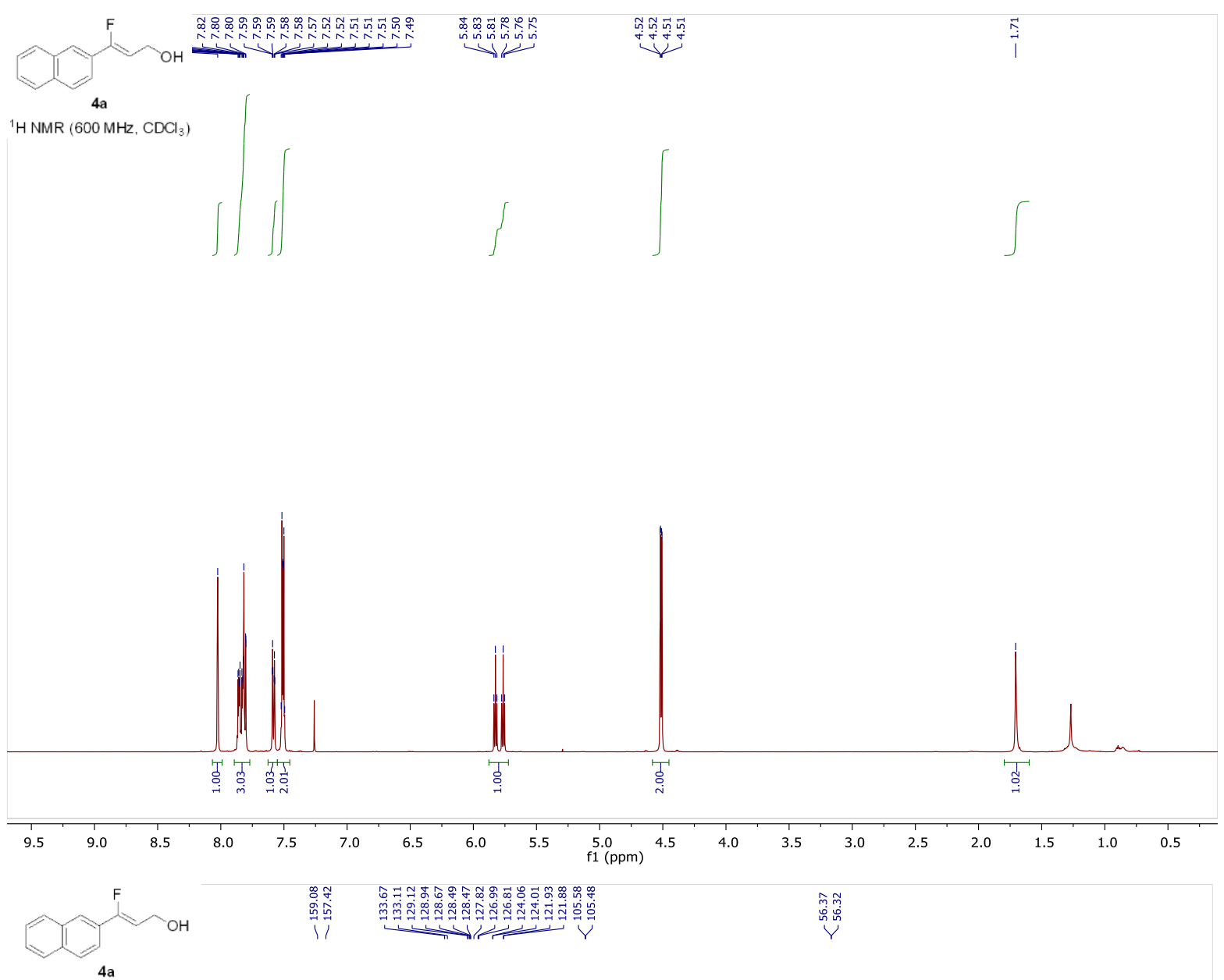

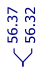

${ }^{13} \mathrm{CNMR}\left(151 \mathrm{MHz}, \mathrm{CDCl}_{3}\right)$

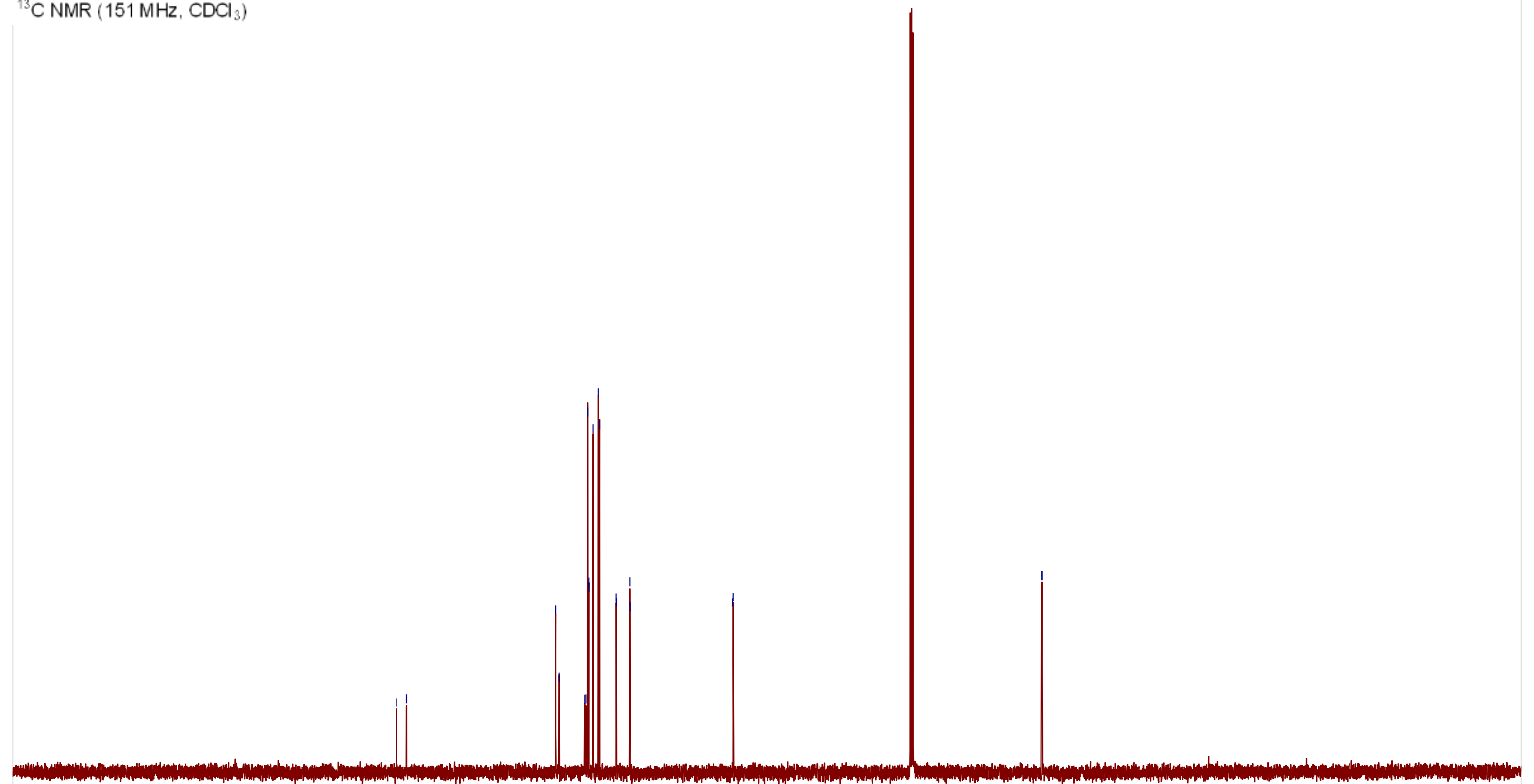

\begin{tabular}{lllllllllllllllllllllllllll}
\hline 20 & 210 & 200 & 190 & 180 & 170 & 160 & 150 & 140 & 130 & 120 & 110 & 100 & 90 & 80 & 70 & 60 & 50 & 40 & 30 & 20 & 10 & 0 & -10 &
\end{tabular} 


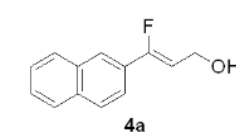

\begin{tabular}{ll}
$\stackrel{m}{9}$ \\
$\stackrel{0}{7}$ & \multirow{1}{7}{} \\
1 & 1
\end{tabular}

${ }^{19} \mathrm{~F} \mathrm{NMR}\left(565 \mathrm{MHz}, \mathrm{CDCl}_{3}\right)$
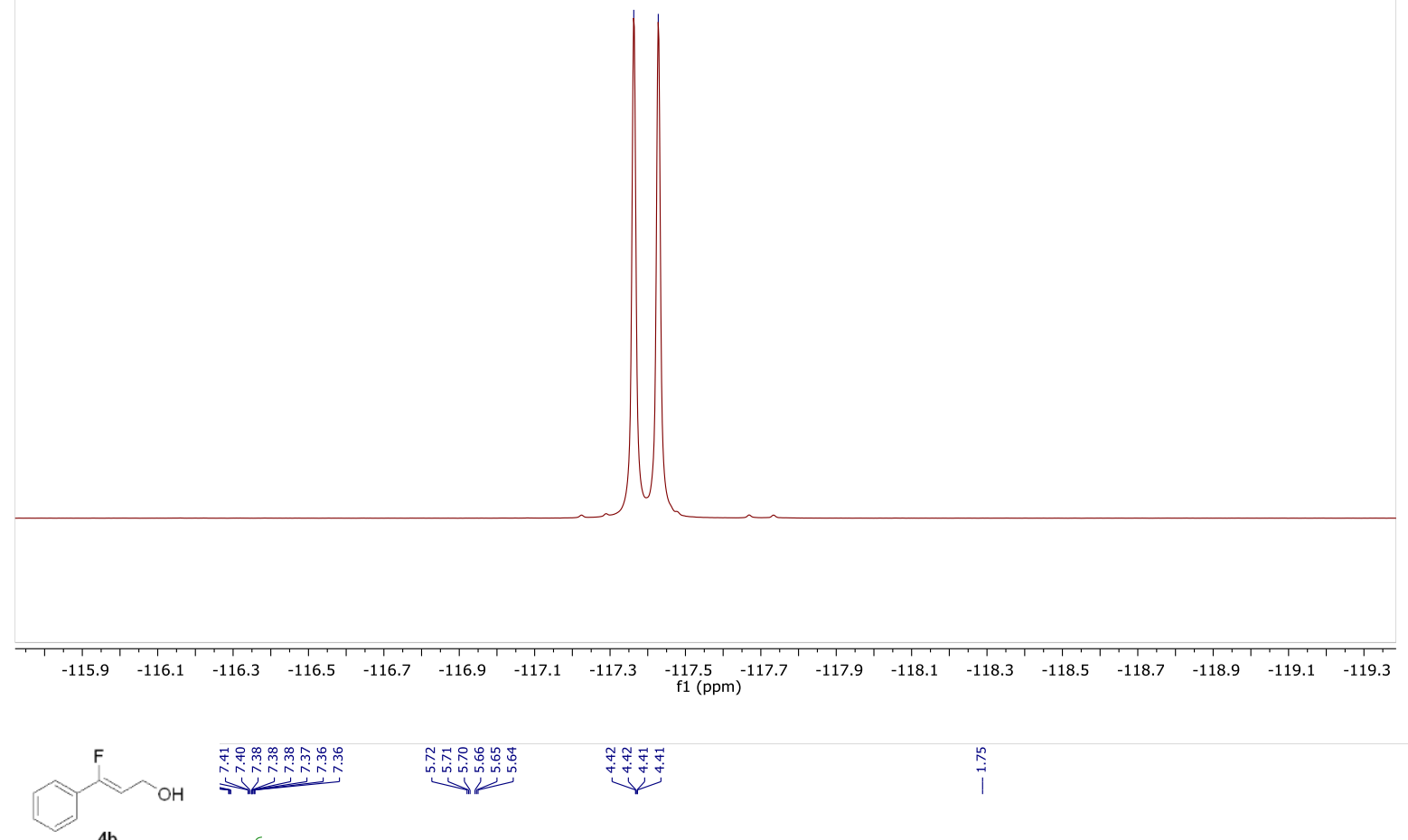

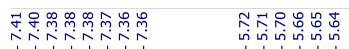

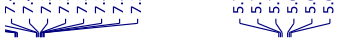

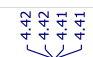

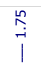

${ }^{1} \mathrm{H}$ NMR $\left(600 \mathrm{MHz}, \mathrm{CD}_{2} \mathrm{Cl}_{2}\right.$ )
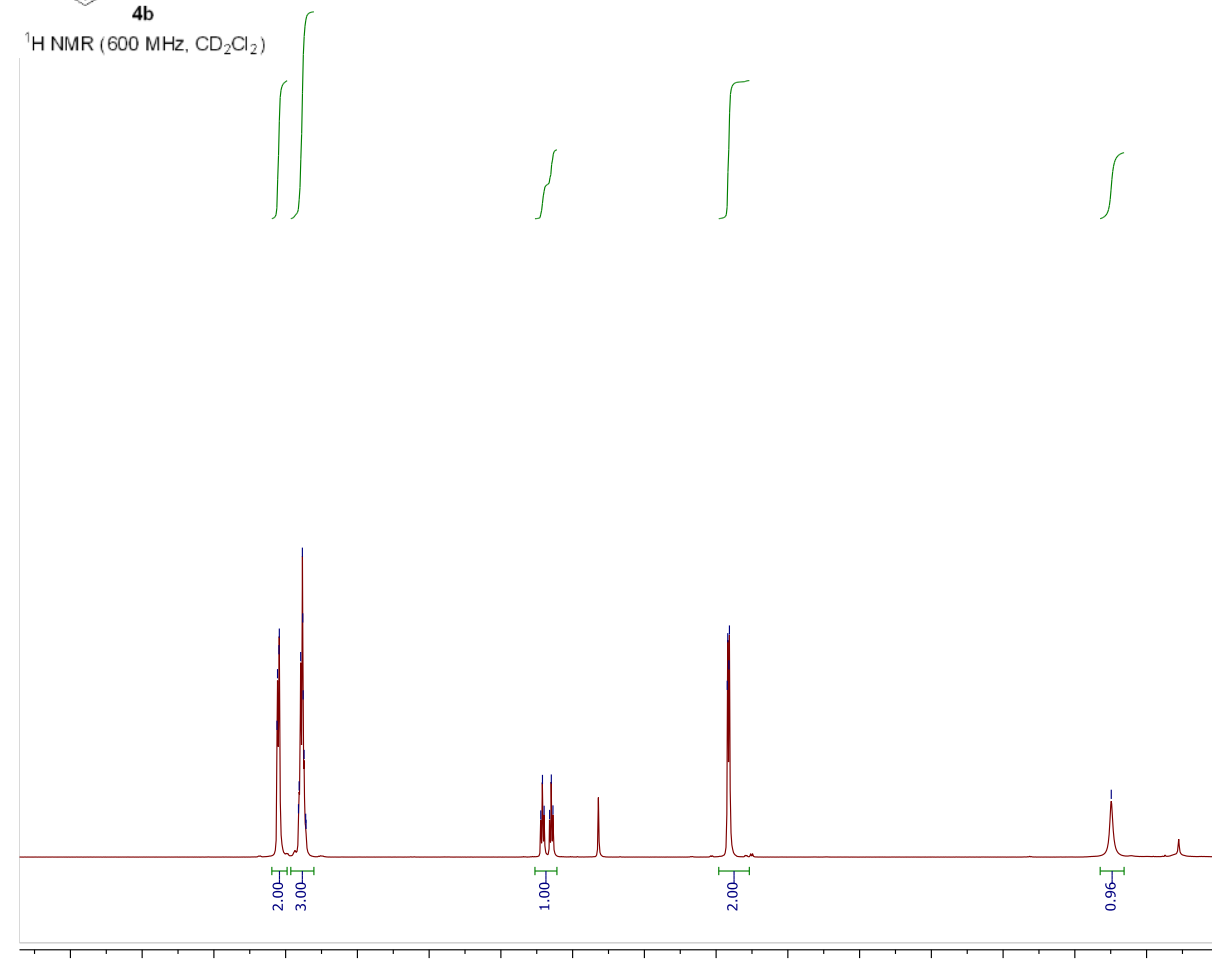

$\begin{array}{llllll}9.0 & 8.5 & 8.0 & 7.5 & 7.0 & 6.5\end{array}$

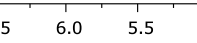

$\begin{array}{lll}5.0 & 4.5 & 4.0 \\ & & \end{array} .5$ 

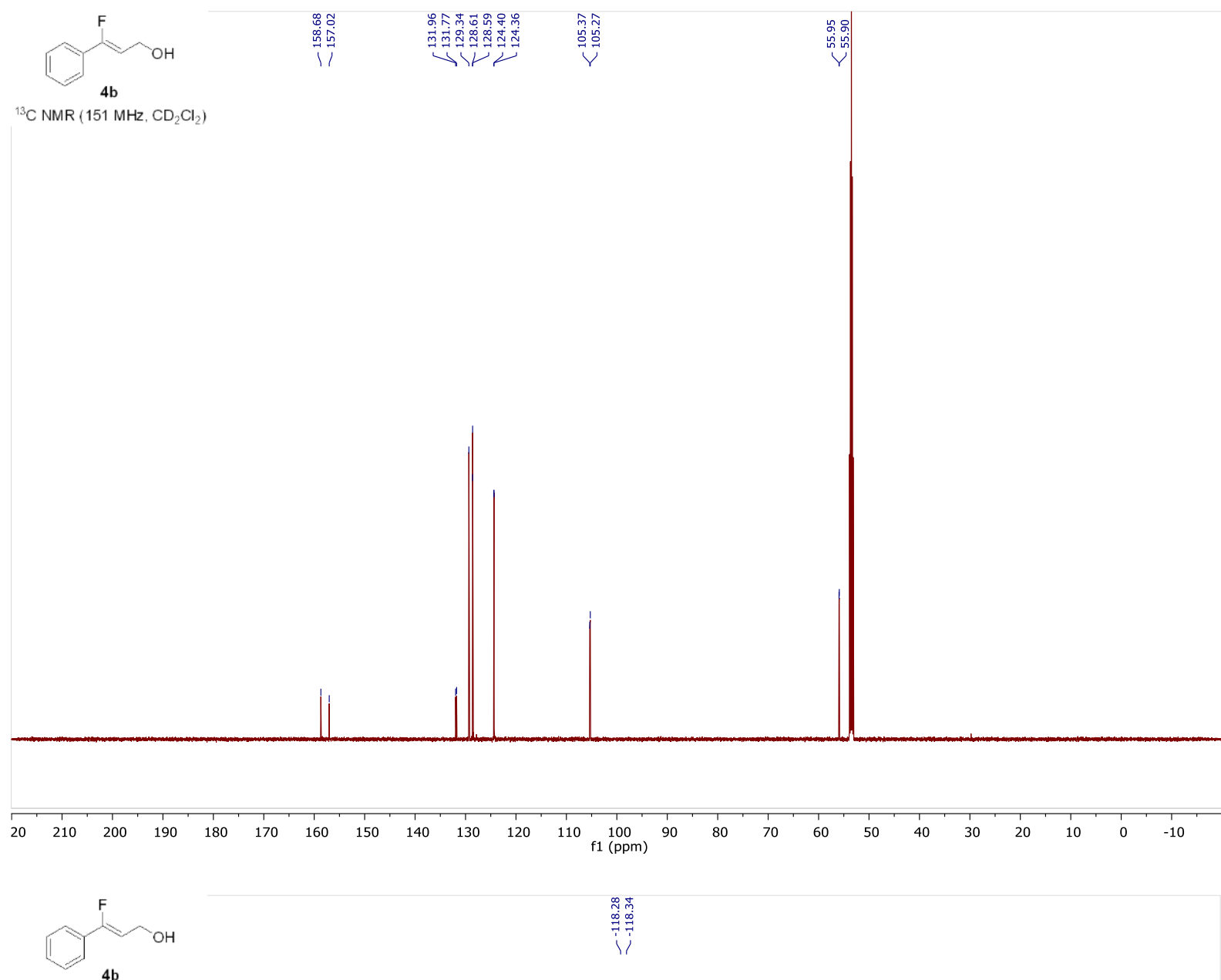

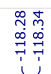

${ }^{19} \mathrm{~F} \mathrm{NMR}\left(565 \mathrm{MHz}, \mathrm{CD}_{2} \mathrm{Cl}_{2}\right)$

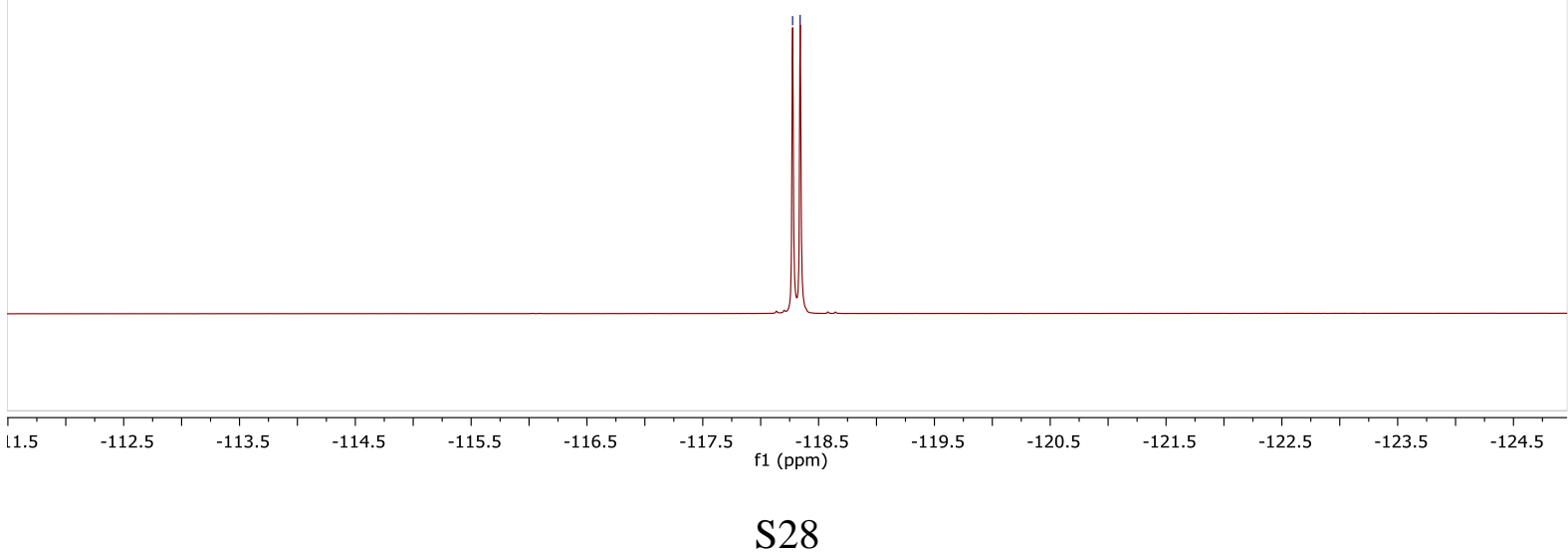



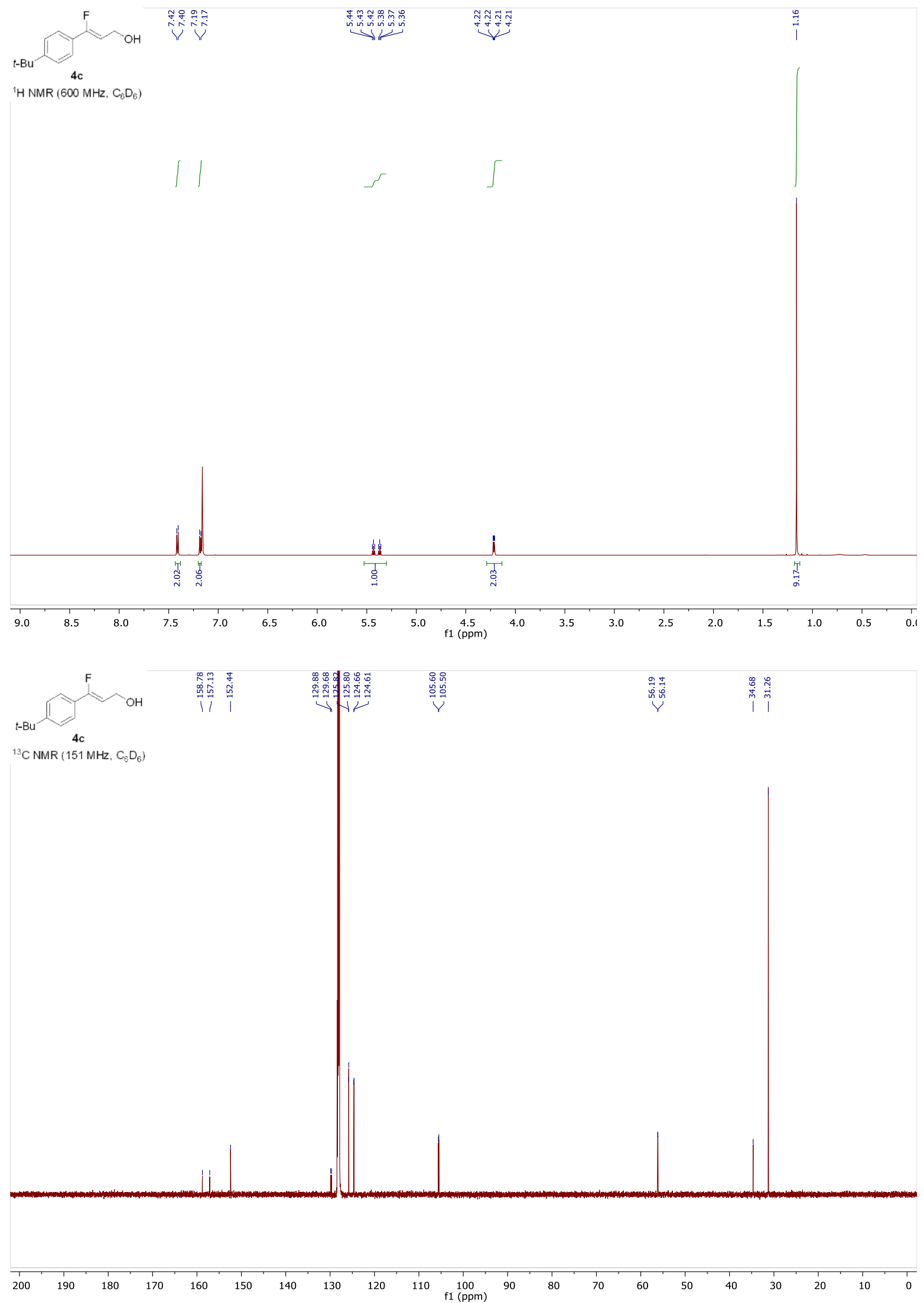


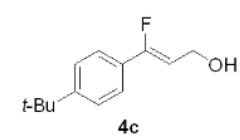

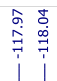

${ }^{19} \mathrm{~F} \mathrm{NMR}\left(565 \mathrm{MHz}, \mathrm{C}_{6} \mathrm{D}_{6}\right)$

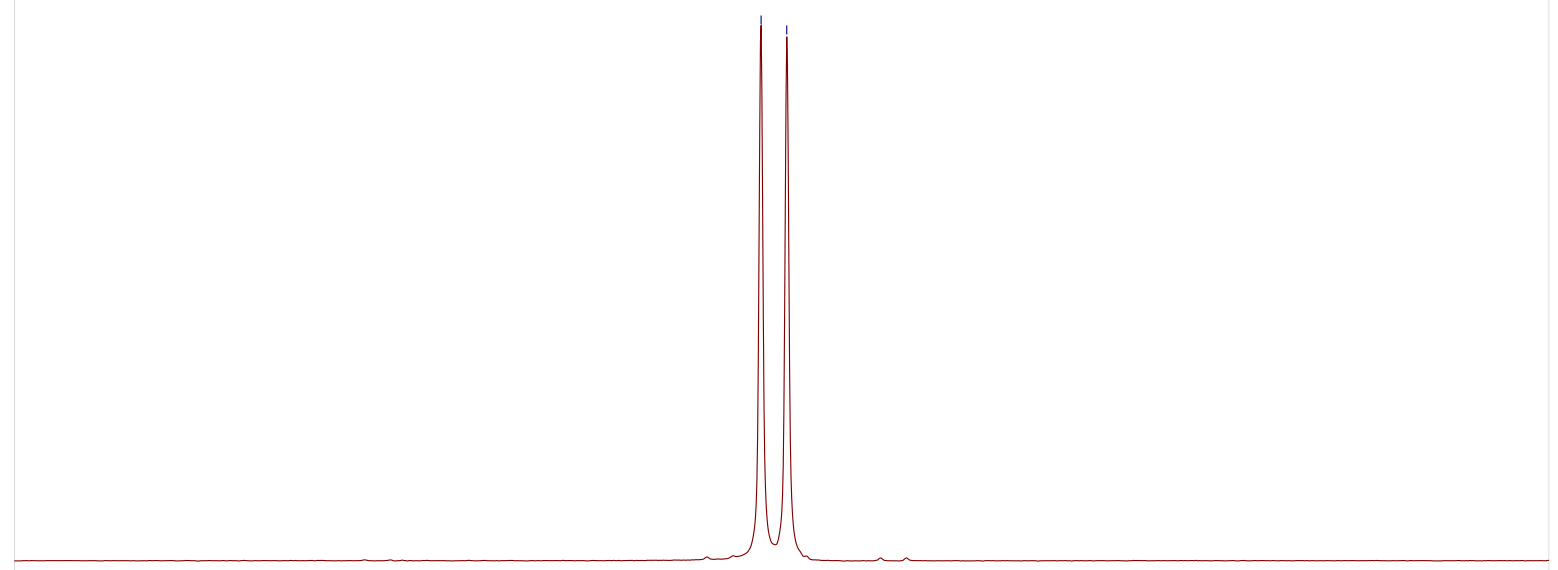
$\begin{array}{lllllllllllllllllllllll} & 16.1 & -116.3 & -116.5 & -116.7 & -116.9 & -117.1 & -117.3 & -117.5 & -117.7 & -117.9 & -118.1 & -118.3 & -118.5 & -118.7 & -118.9 & -119.1 & -119.3 & -119.5 & -119.7 & -119.9\end{array}$

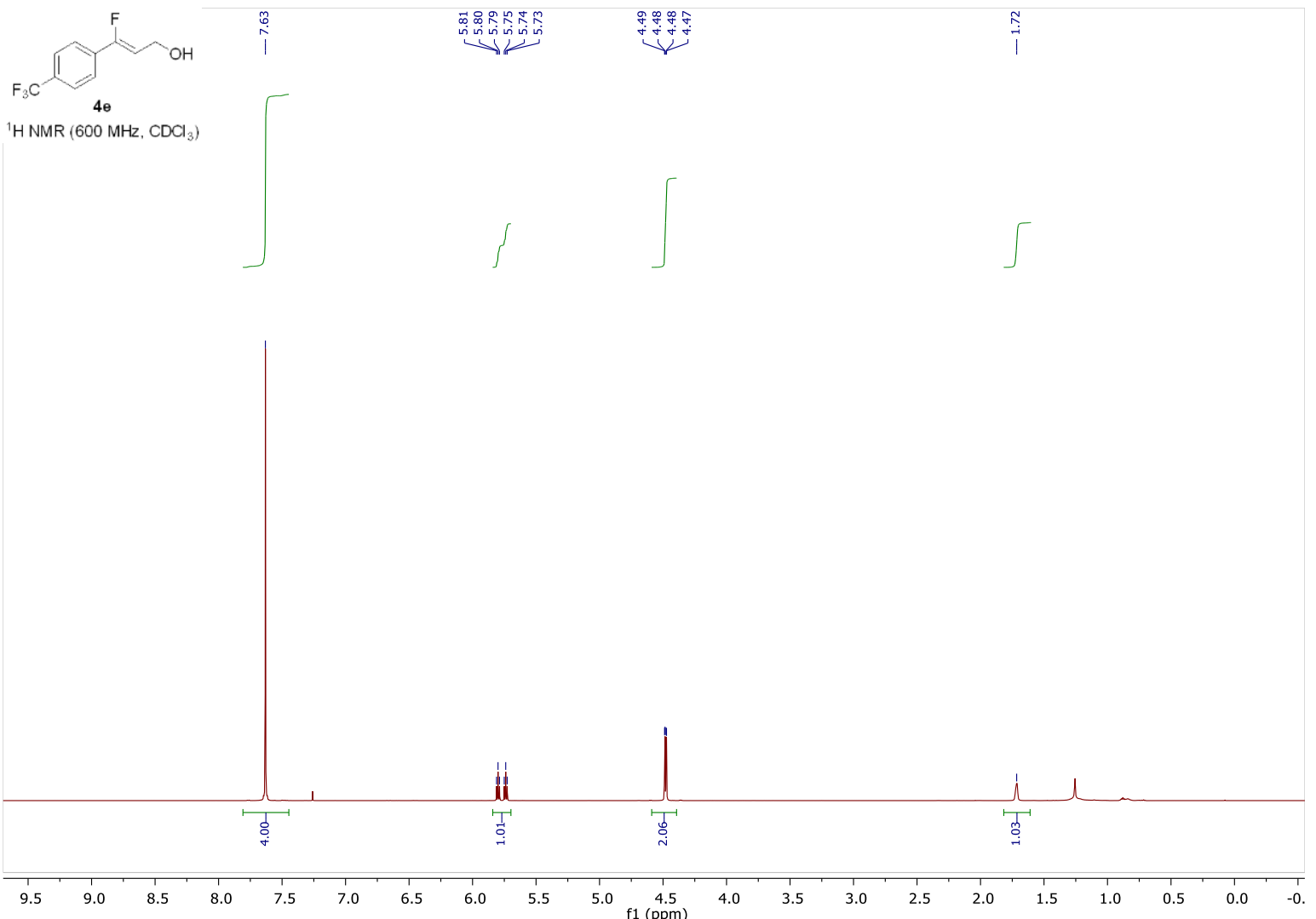



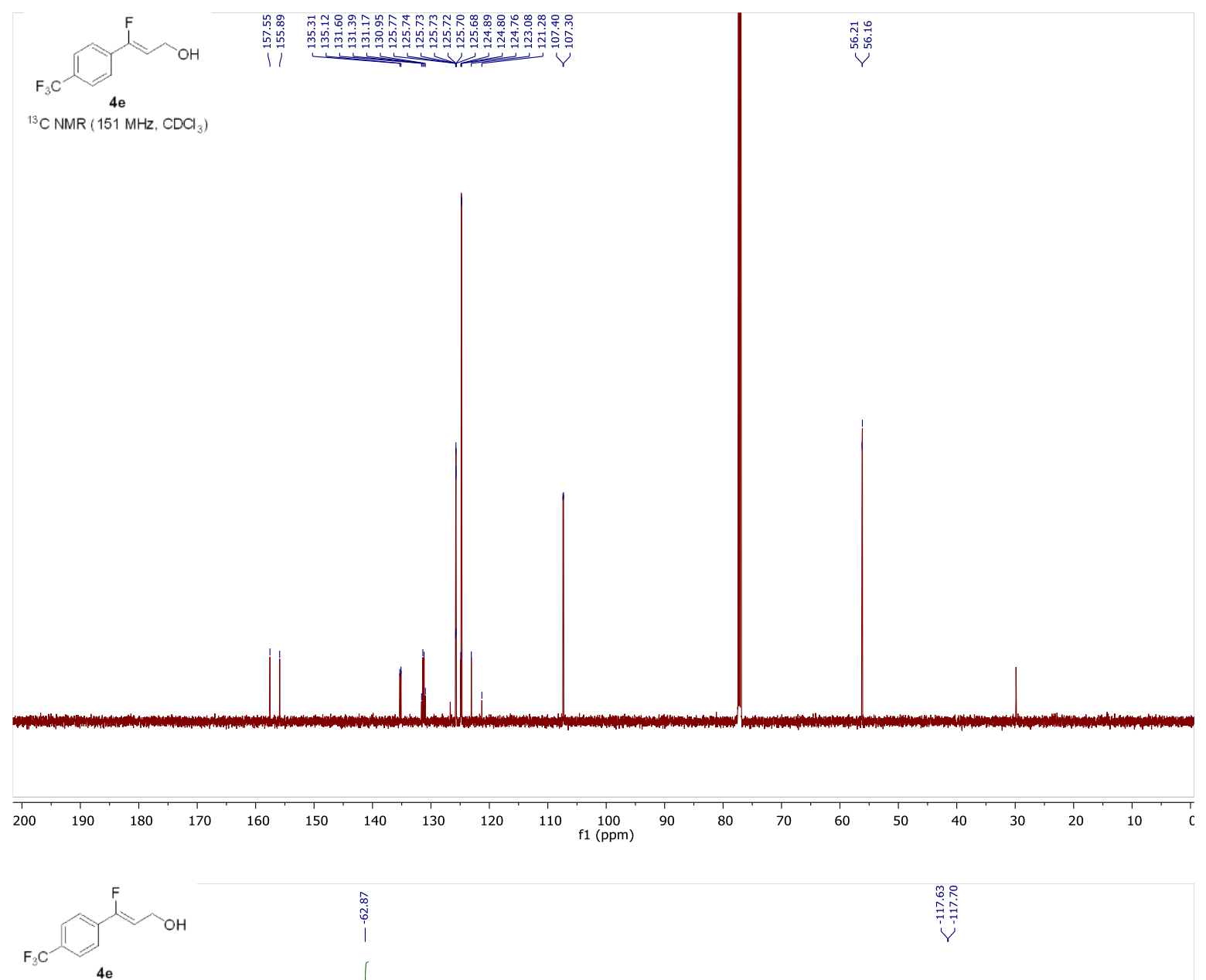

$\hat{\infty}$
$\dot{\omega}$
$\dot{j}$

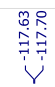

${ }^{19} \mathrm{~F}$ NMR $\left(565 \mathrm{MHz}, \mathrm{CDCl}_{3}\right)$
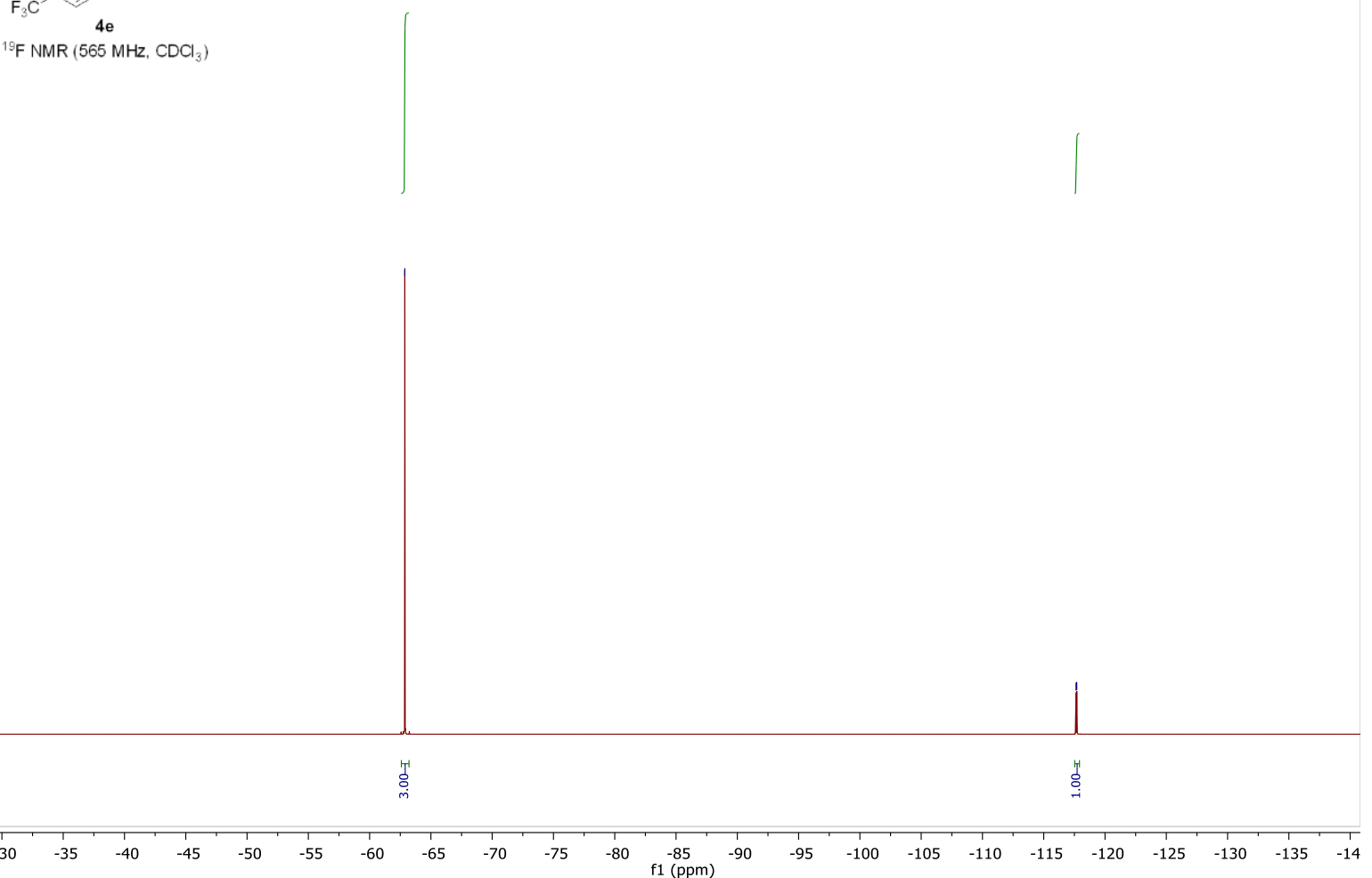


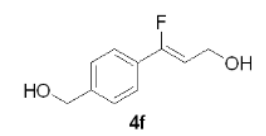

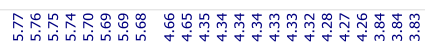

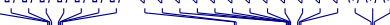

${ }^{1} \mathrm{H}$ NMR $\left(600 \mathrm{MHz}\right.$, Acetone-d $\left.\mathrm{d}_{6}\right)$
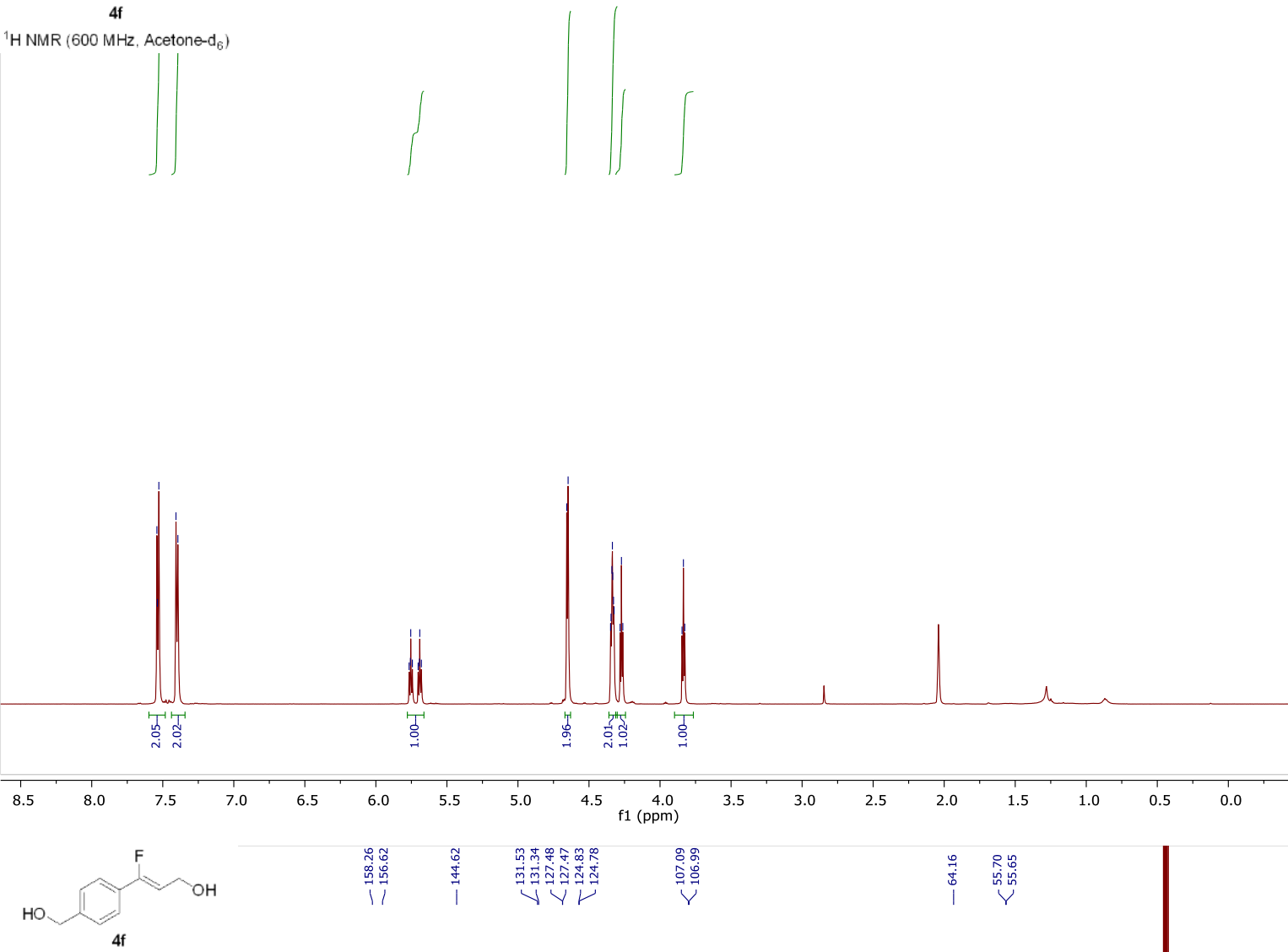

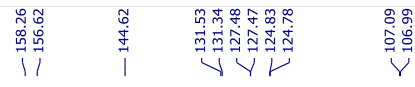

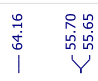

${ }^{13} \mathrm{C}$ NMR (151 MHz, Acetone- $\left.\mathrm{d}_{6}\right)$

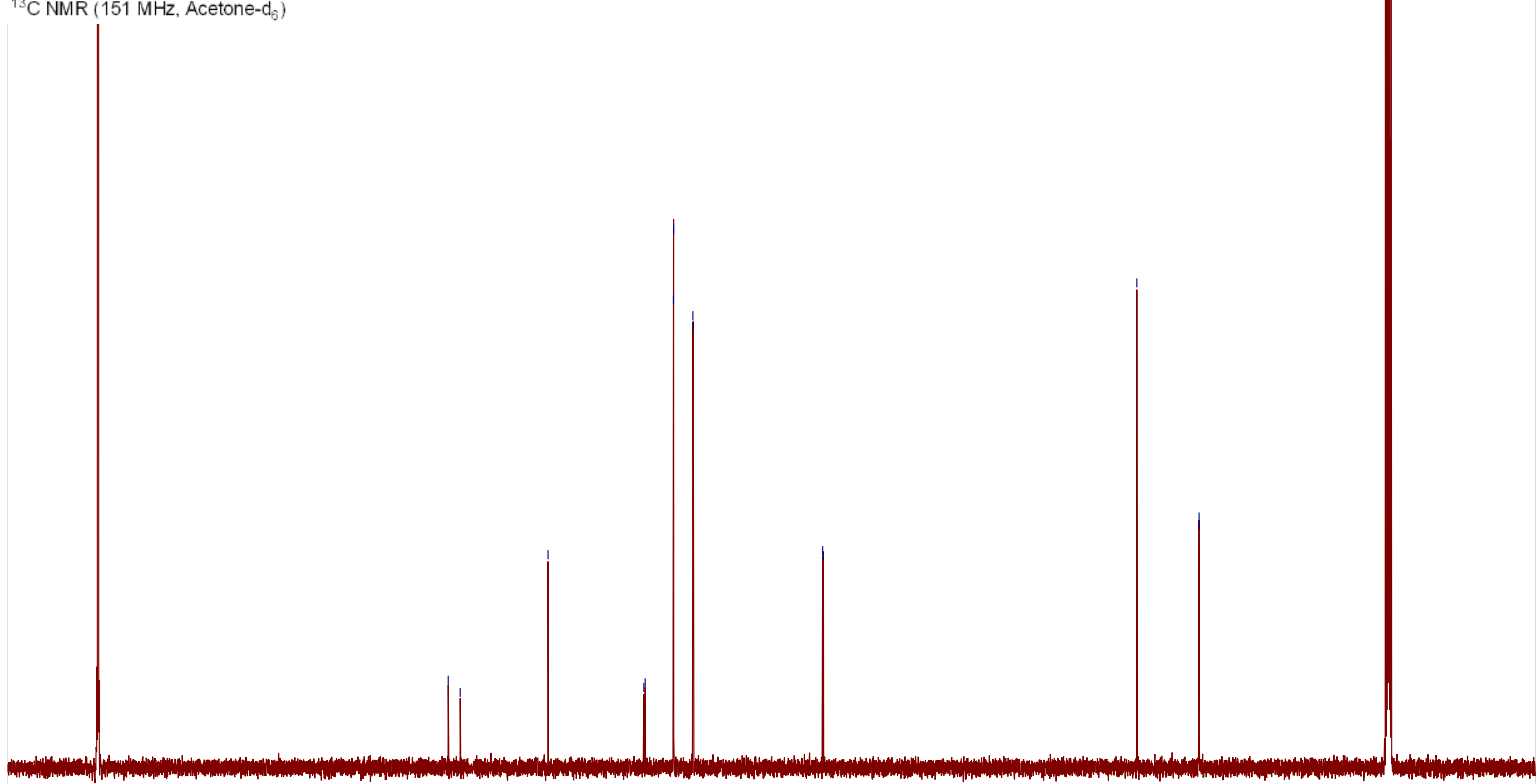

$\begin{array}{llllllllll}210 & 200 & 190 & 180 & 170 & 160 & 150 & 140 & 130 & 120 \begin{array}{c}110 \\ \mathrm{f} 1(\mathrm{ppm})\end{array}\end{array}$ 


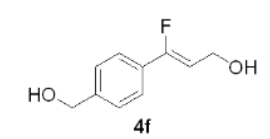

${ }^{18} \mathrm{~F}$ NMR $\left(565 \mathrm{MHz}\right.$, Acetone-d $\left.\mathrm{d}_{\hat{\vartheta}}\right)$
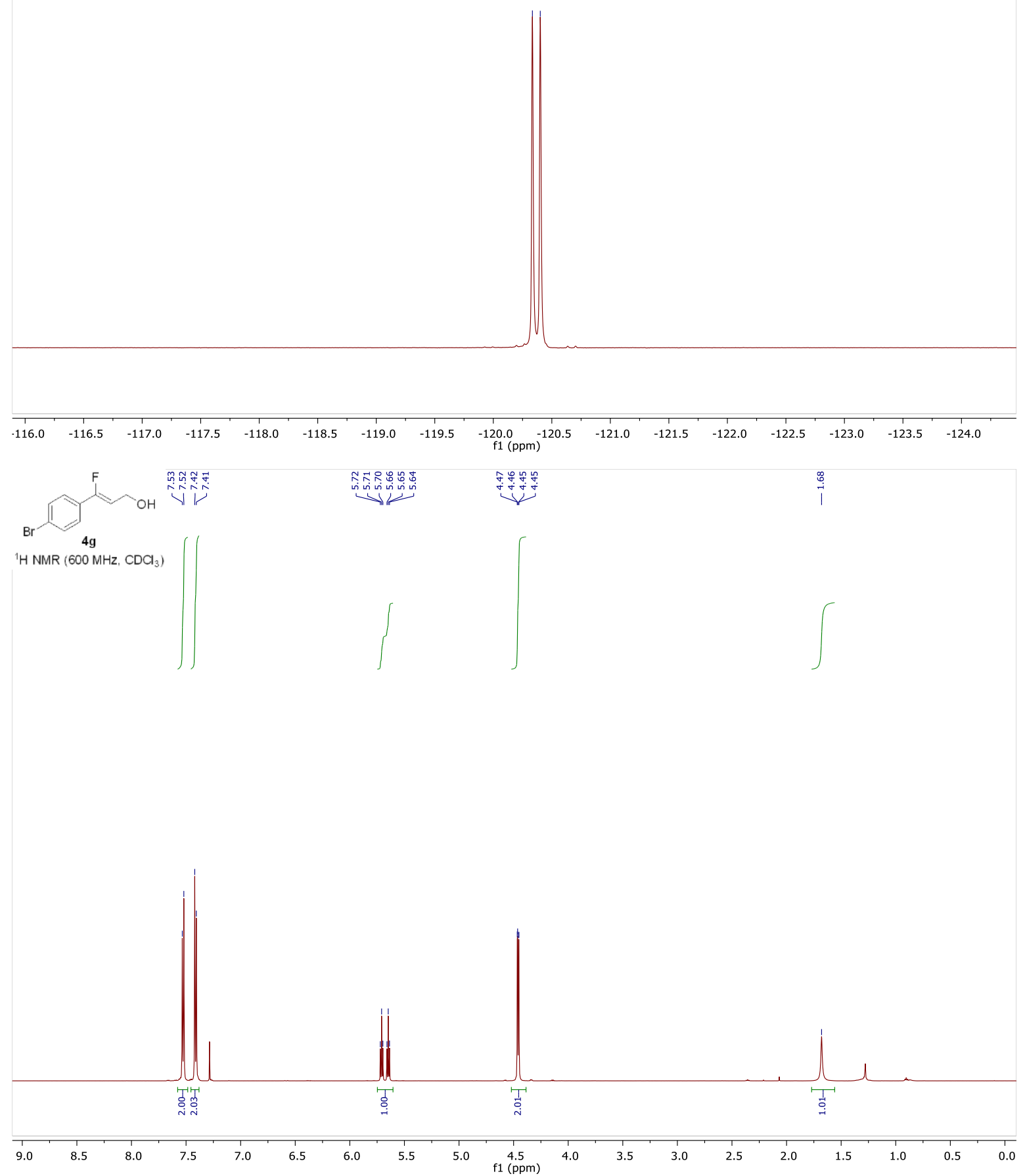

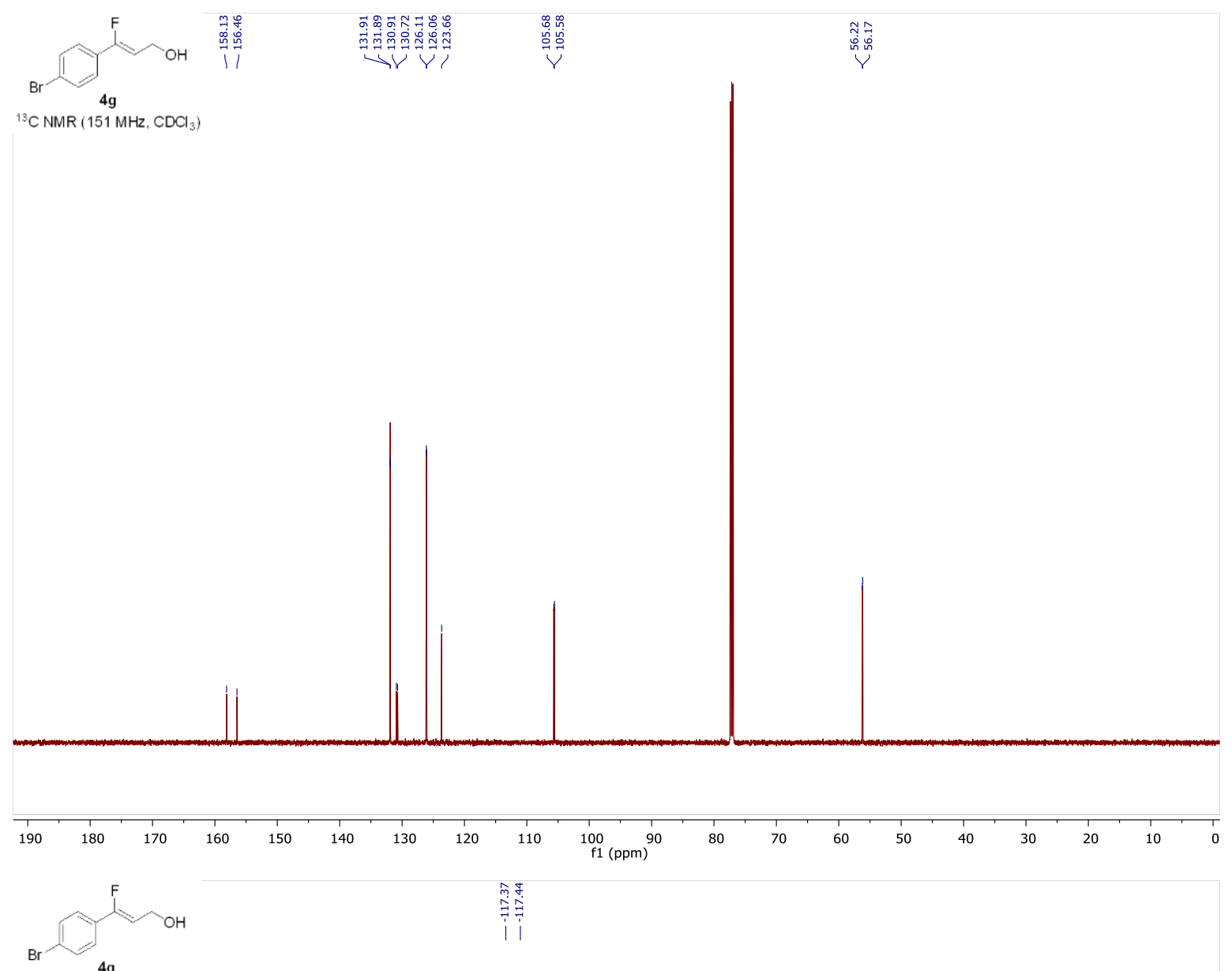

角势

${ }^{9} \mathrm{~F} \mathrm{NMR}\left(565 \mathrm{MHz}, \mathrm{CDCl}_{3}\right)$

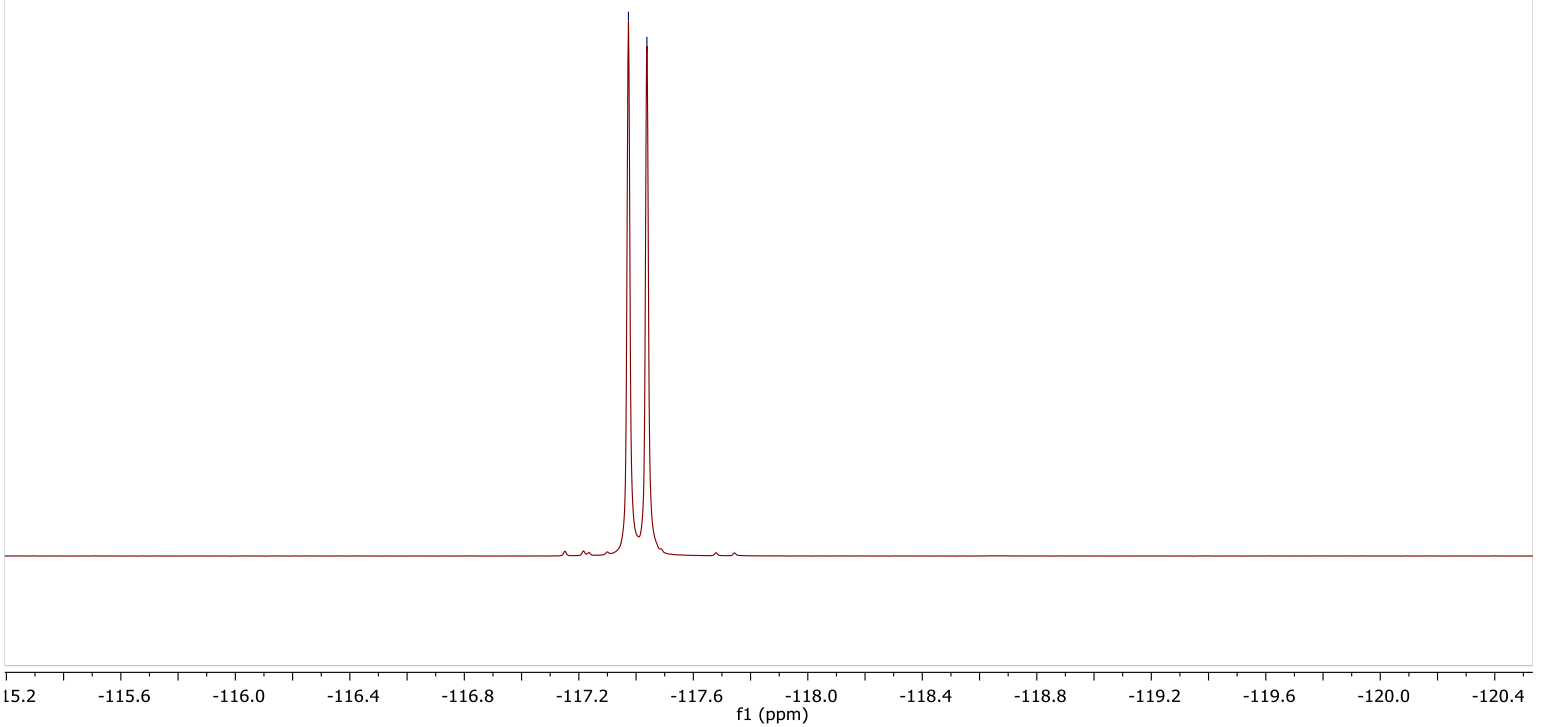



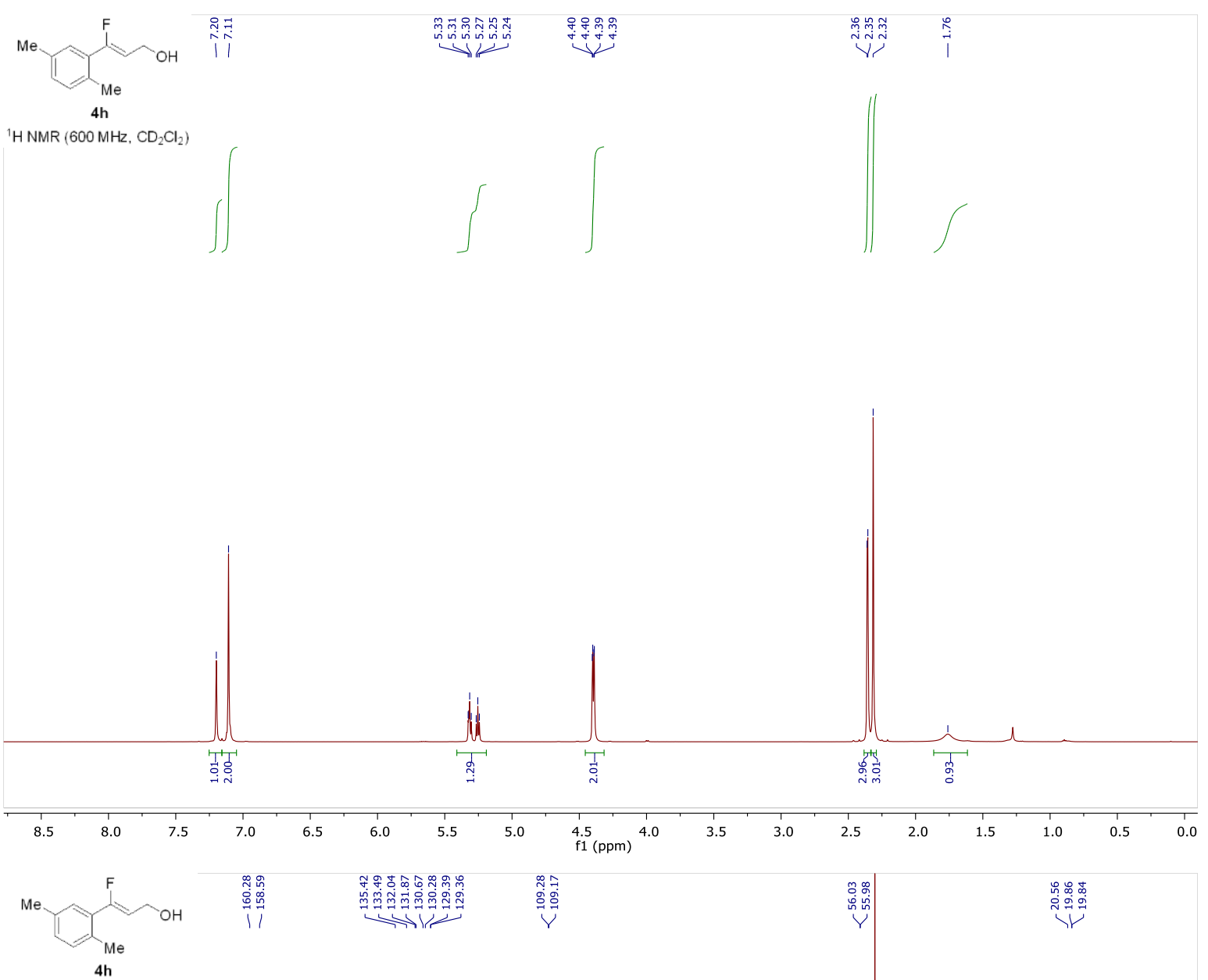

垈

${ }^{13} \mathrm{C}$ NMR (151 MHz, $\mathrm{CD}_{2} \mathrm{Cl}_{2}$ )
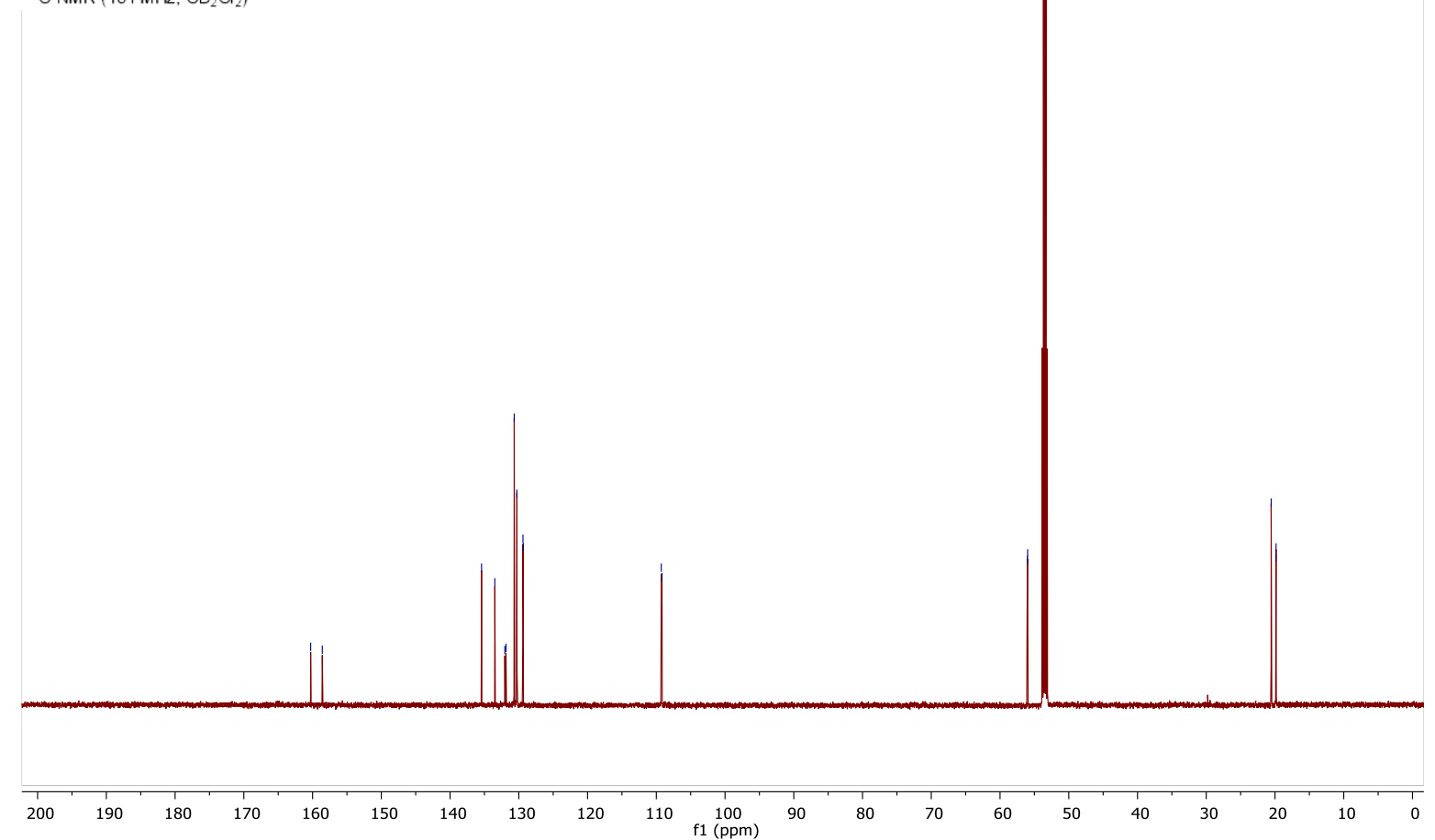


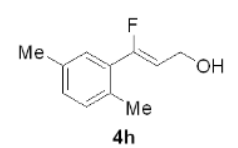

${ }^{19} \mathrm{~F} \mathrm{NMR}\left(565 \mathrm{MHz}, \mathrm{CD}_{2} \mathrm{Cl}_{2}\right)$

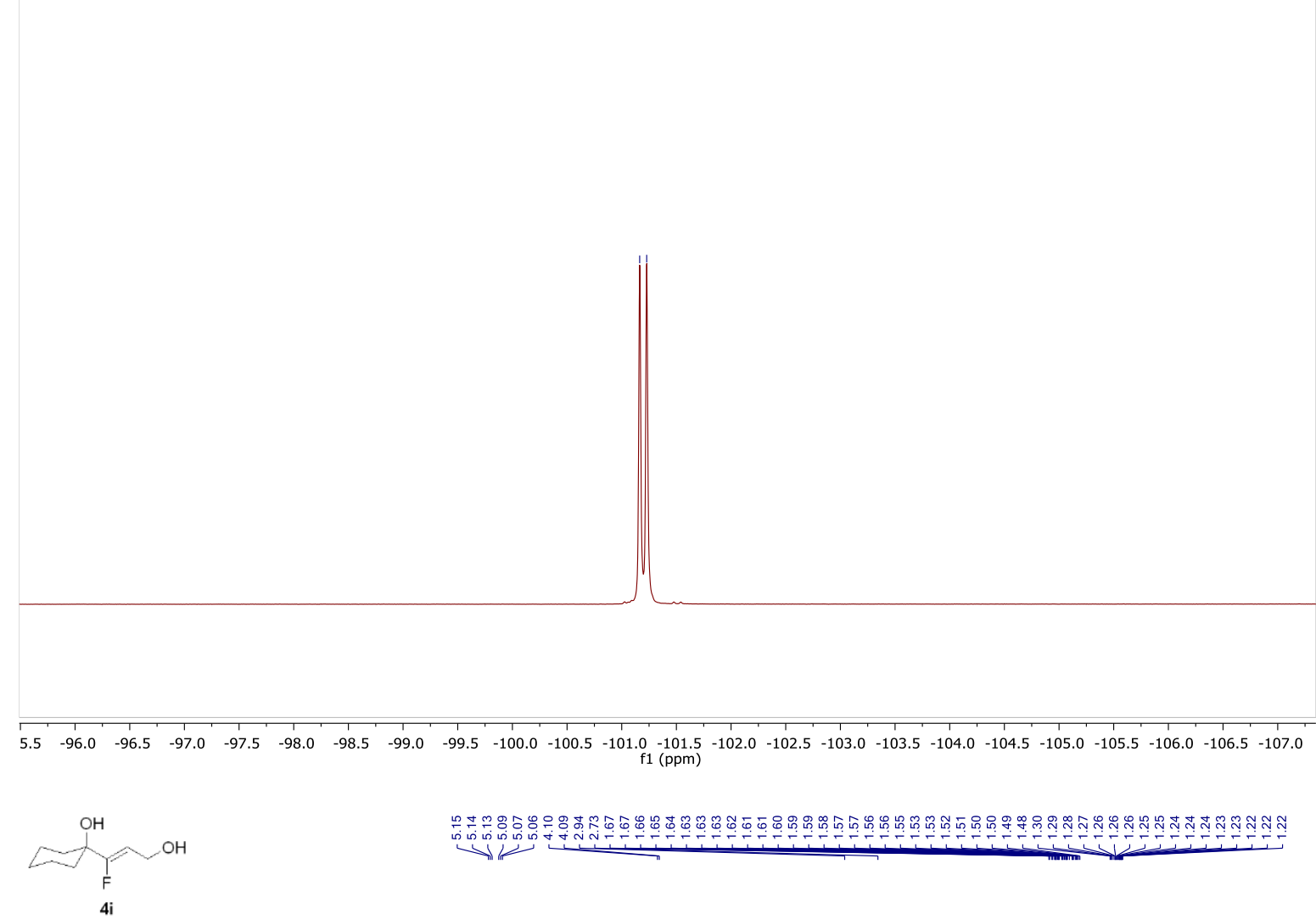

${ }^{1} \mathrm{H}$ NMR (600 MHz, $\mathrm{CD}_{3} \mathrm{CN}$ )

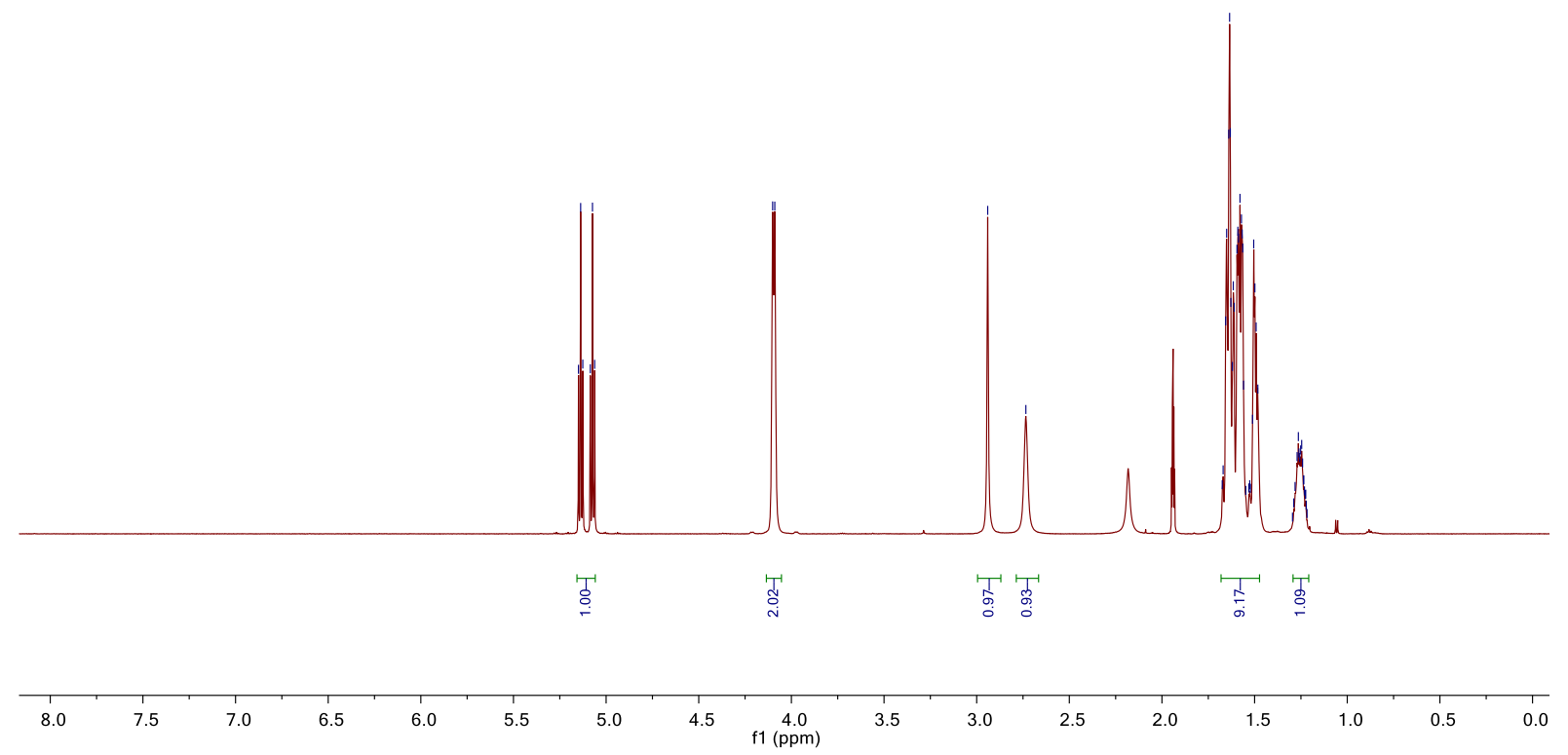




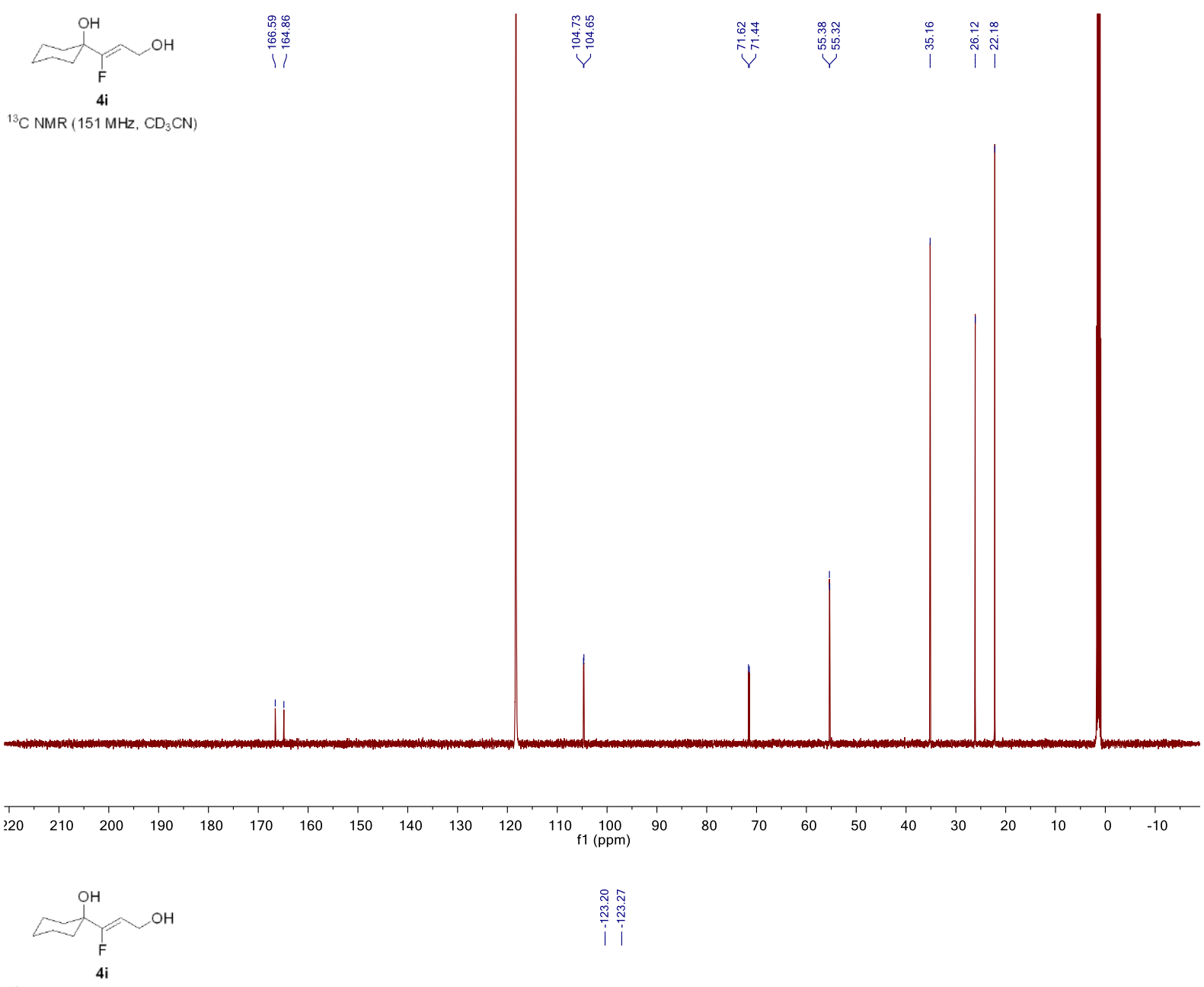

${ }^{19} \mathrm{~F} \mathrm{NMR}\left(565 \mathrm{MHz}, \mathrm{CD}_{3} \mathrm{CN}\right)$

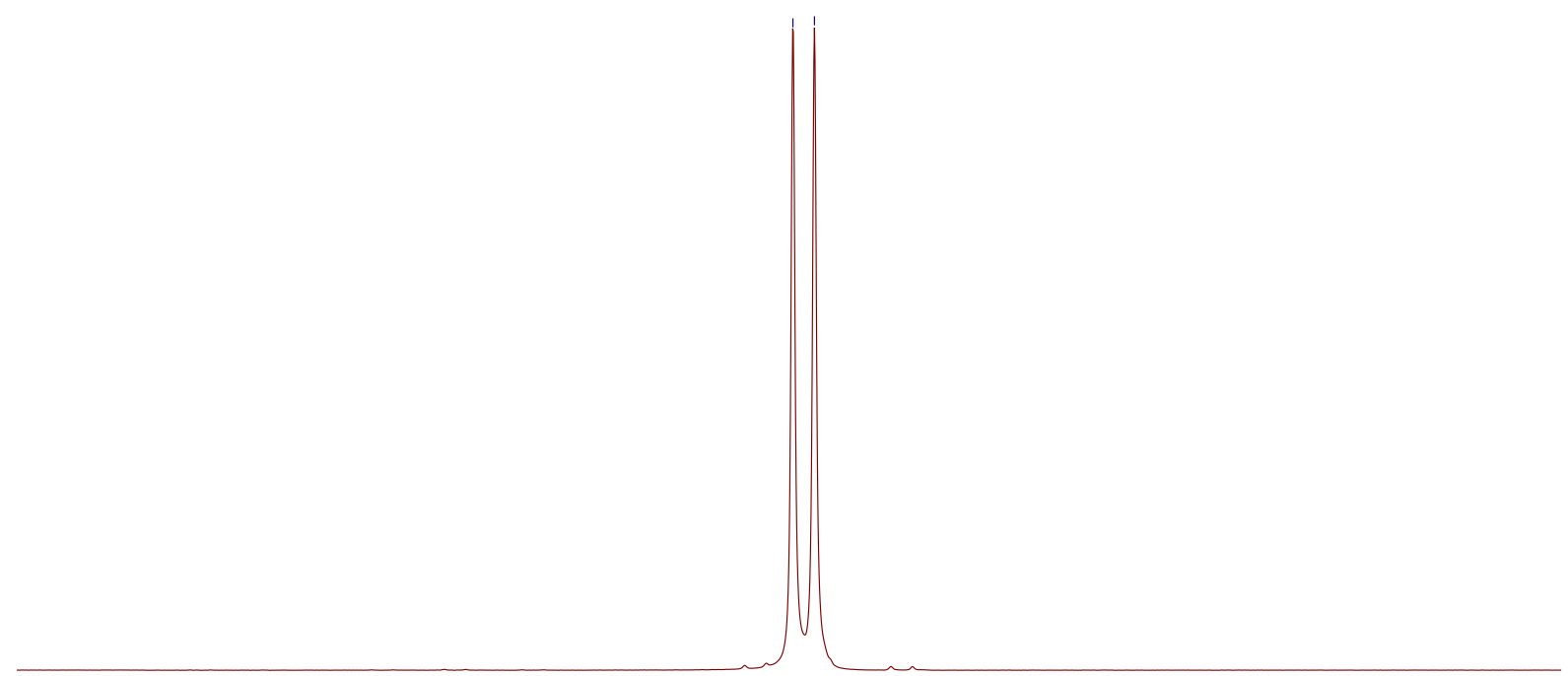

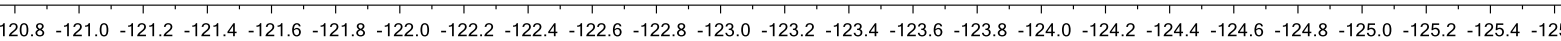
$\mathrm{f} 1(\mathrm{ppm})$ 


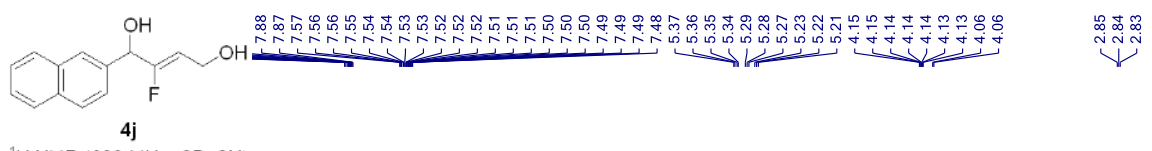

${ }^{1} \mathrm{H} \mathrm{NMR}\left(600 \mathrm{MHz}, \mathrm{CD}_{3} \mathrm{CN}\right)$
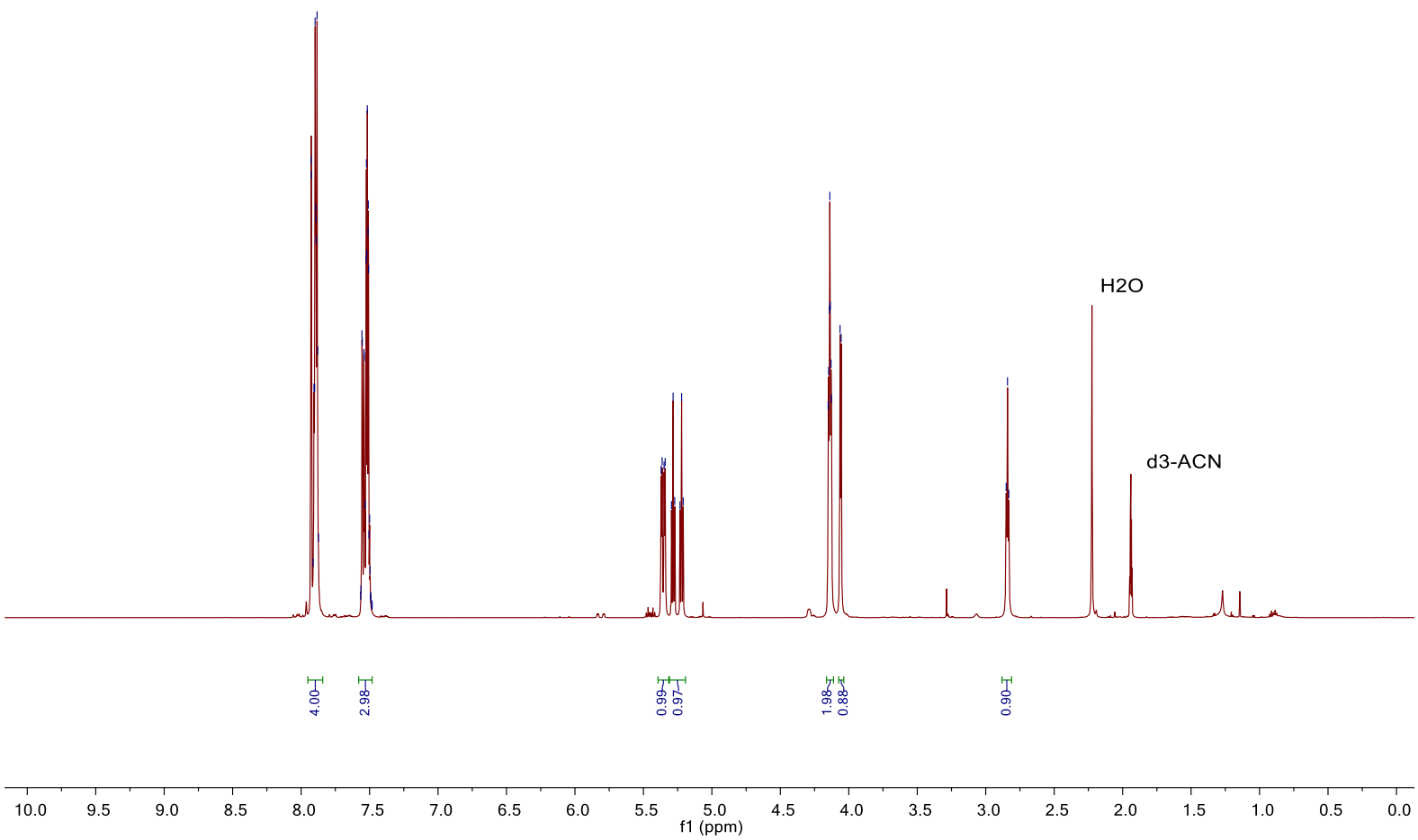

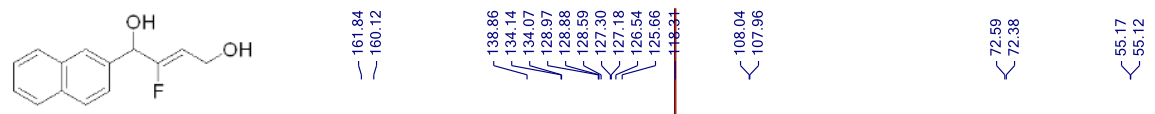

${ }^{13} \mathrm{C}$ NMR $\left(151 \mathrm{MHz}, \mathrm{CD}_{3} \mathrm{CN}\right)$

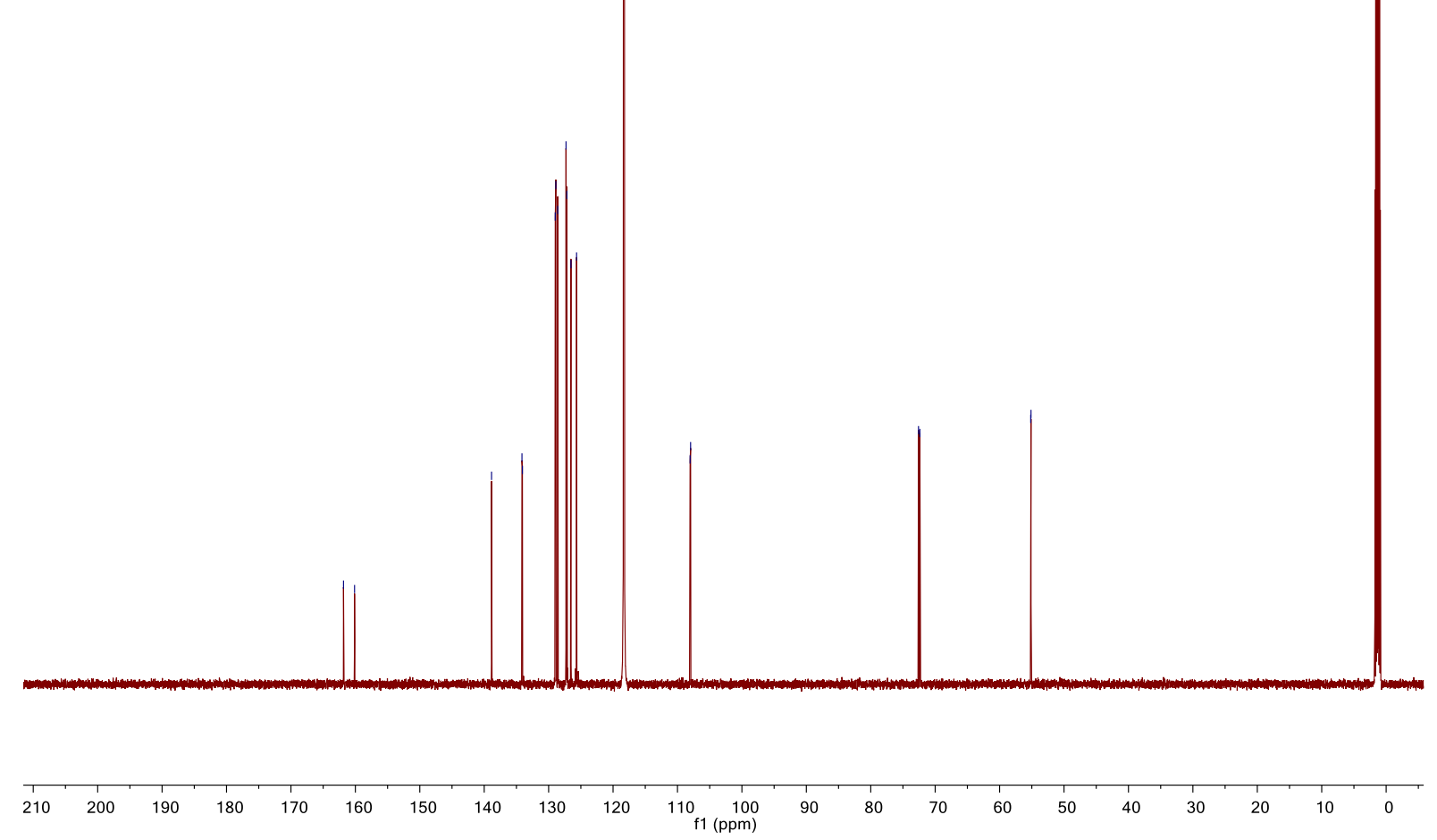




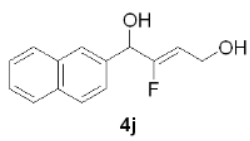

${ }^{19} \mathrm{~F}$ NMR $\left(565 \mathrm{MHz}, \mathrm{CD}_{3} \mathrm{CN}\right)$

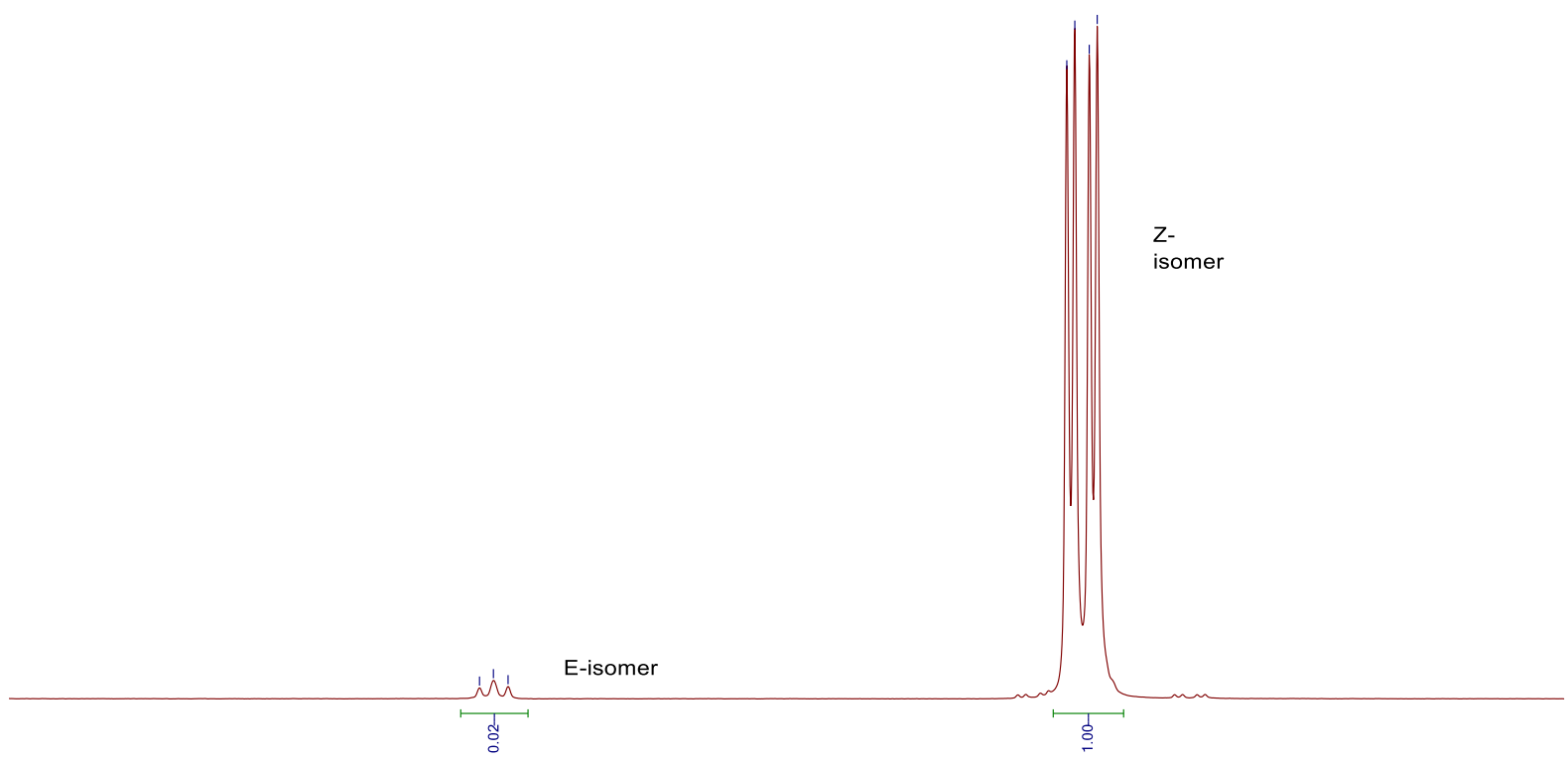

$\begin{array}{lllllllllllllllllllllll}-118.2 & -118.4 & -118.6 & -118.8 & -119.0 & -119.2 & -119.4 & -119.6 & -119.8 & -120.0 & -120.2 & -120.4 & -120.6 & -120.8 & -121.0 & -121.2 & -121.4 & -121.6 & -121.8 & -122.0 & -122.2 & -122.4 & -12\end{array}$

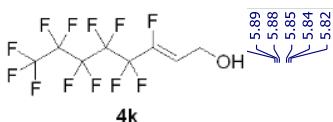

$0 \mathrm{MHz}, \mathrm{CD}_{2} \mathrm{Cl}_{2}$ )
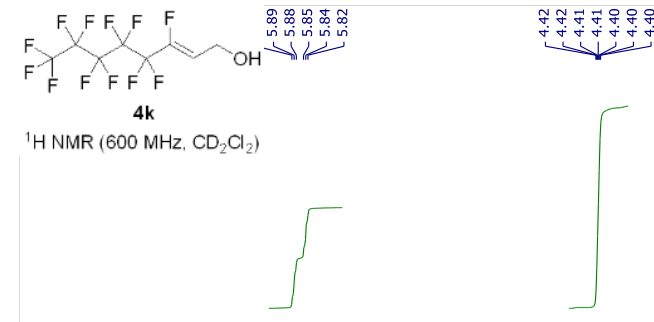

$\stackrel{\substack{i \\ i}}{i}$

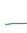
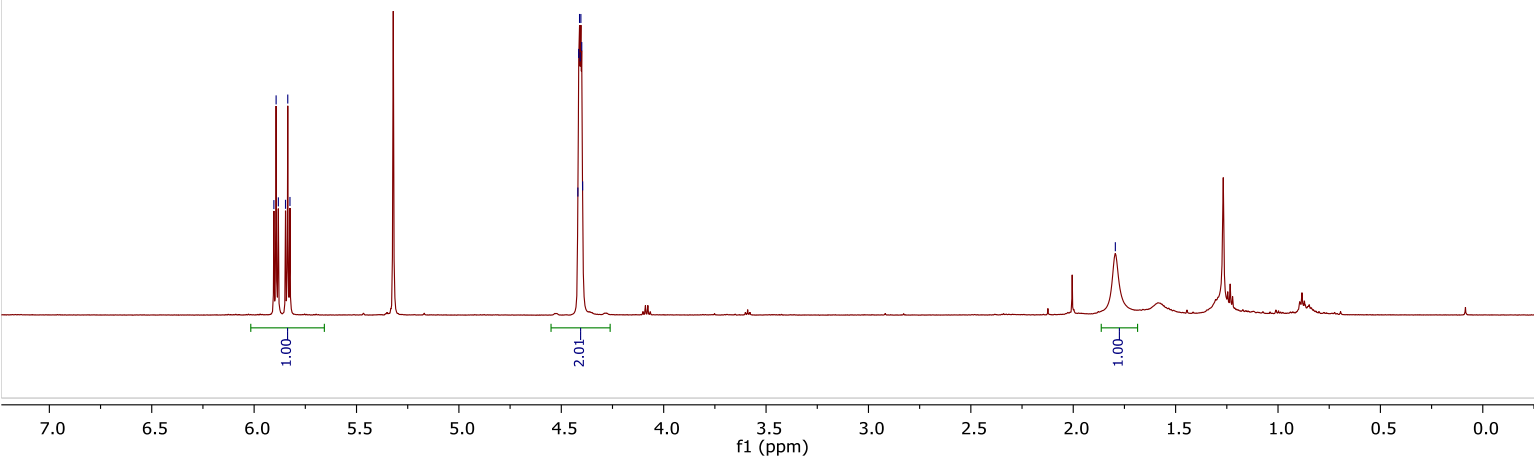

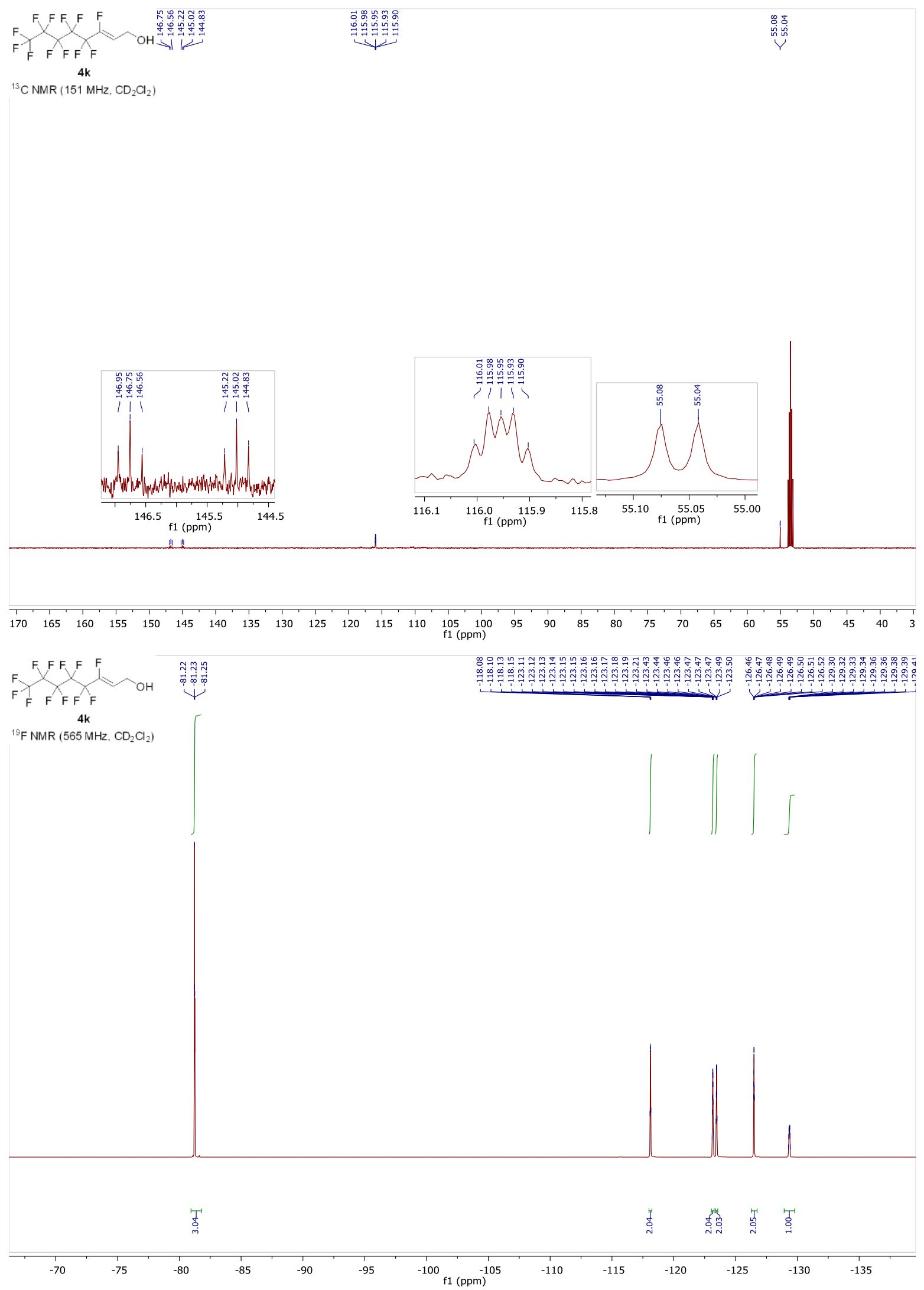

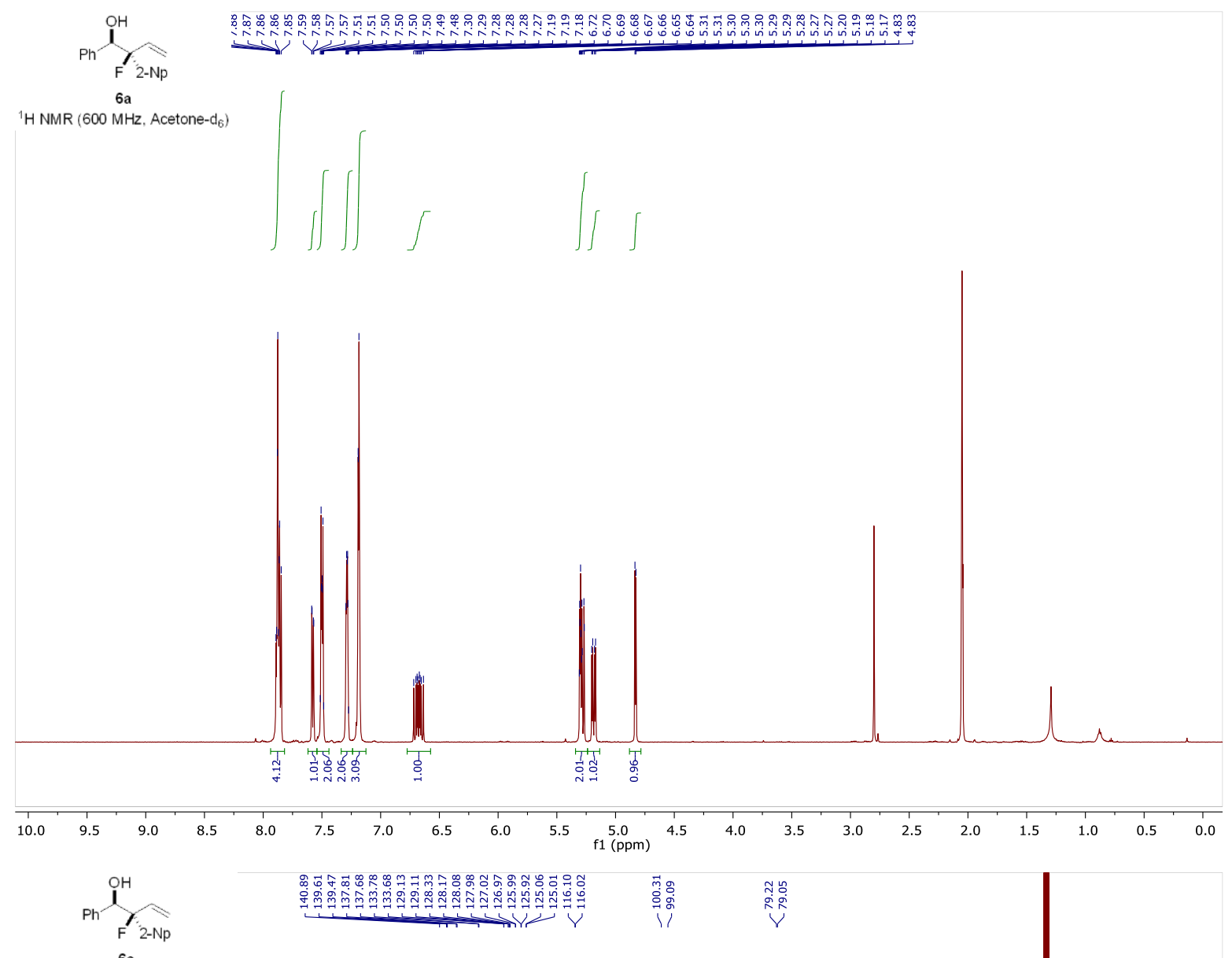

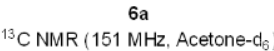

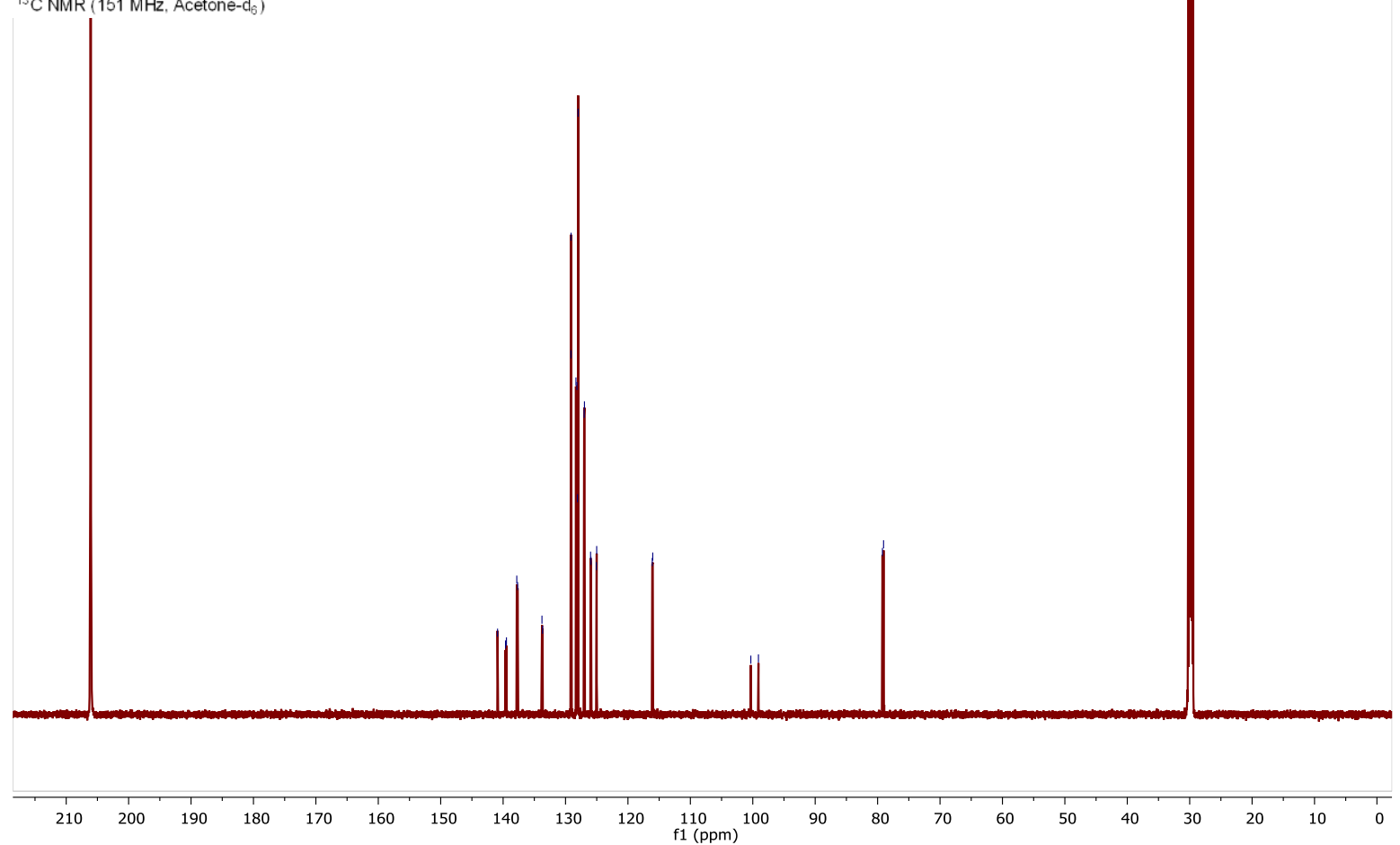




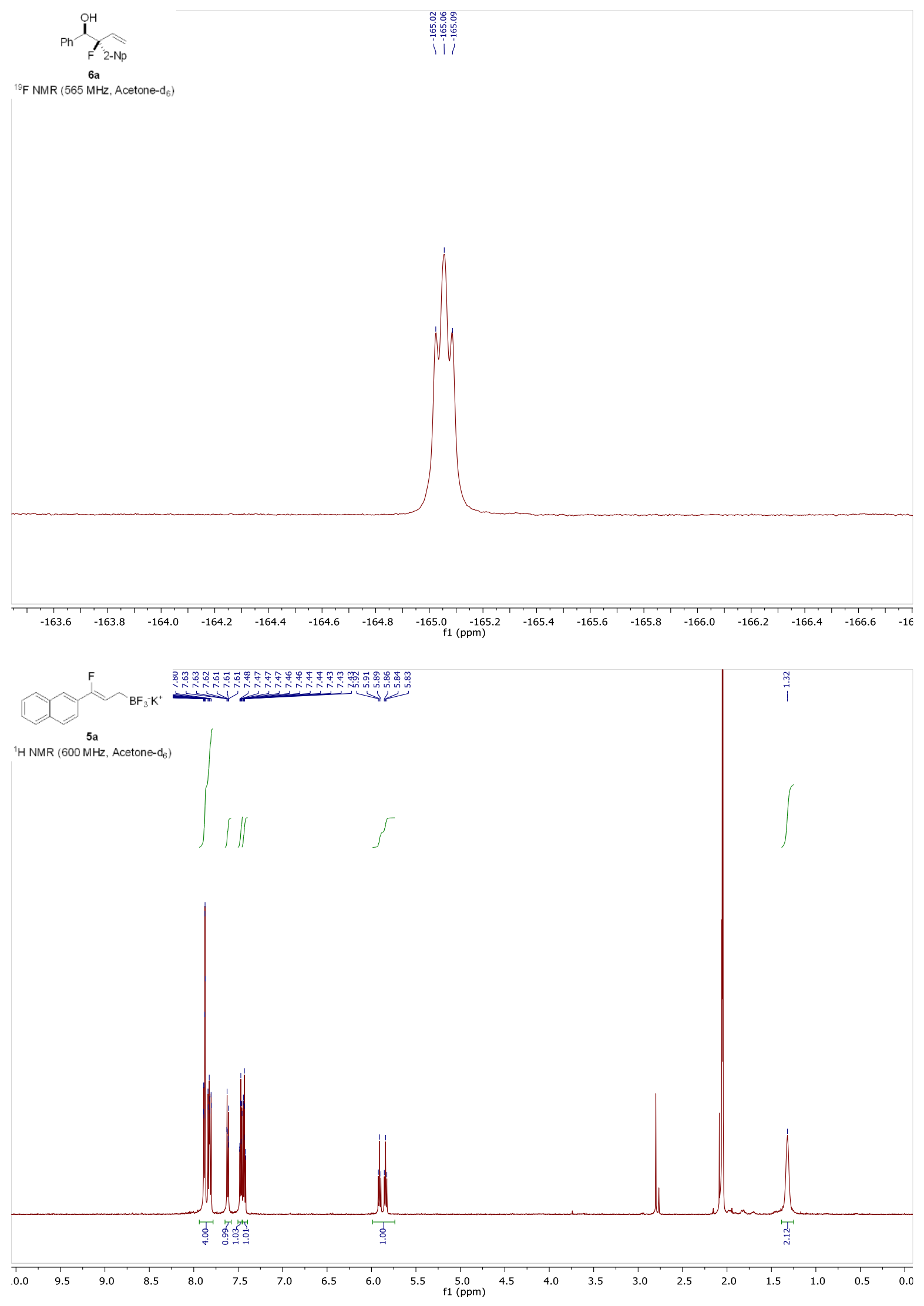



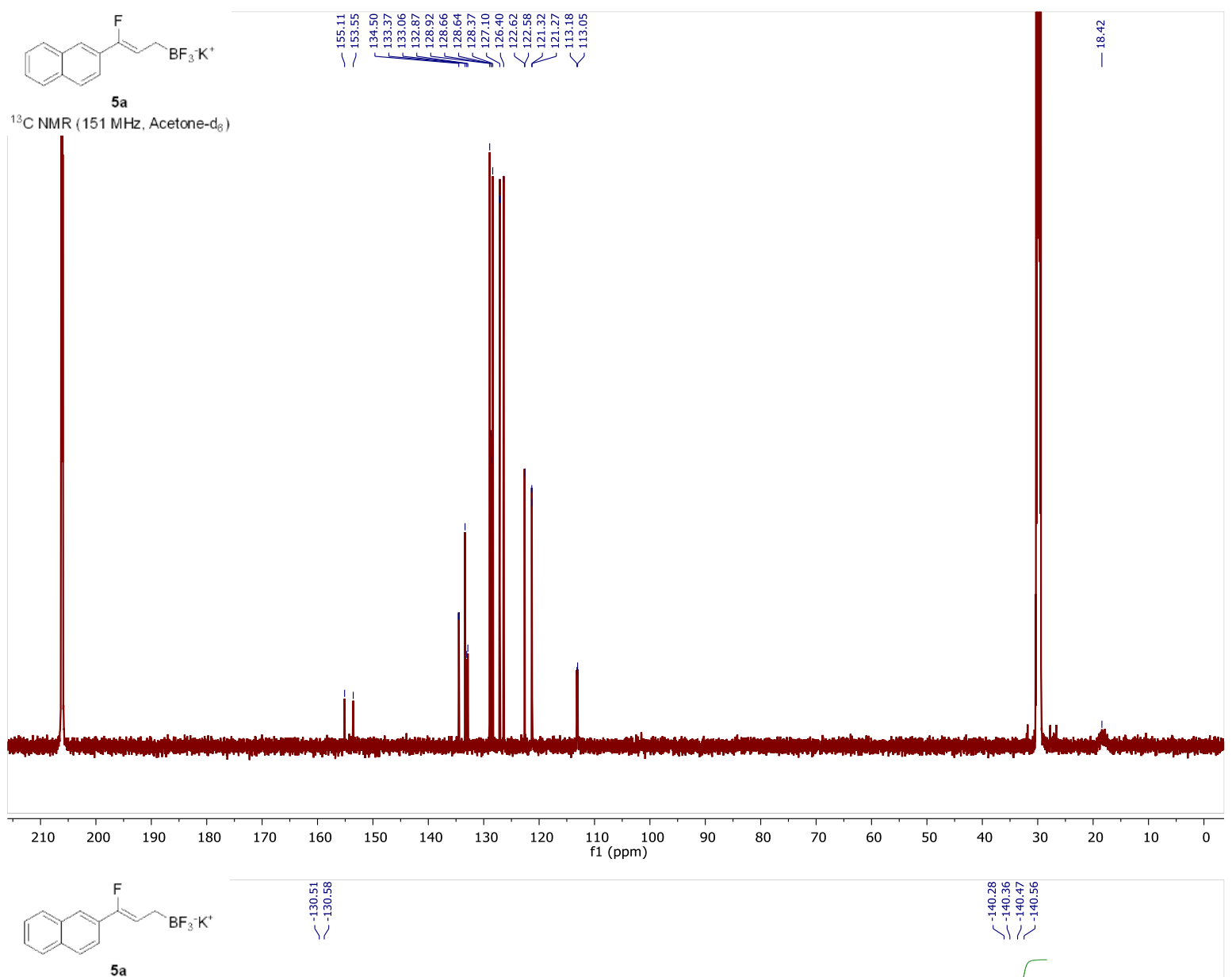

ij

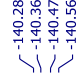

${ }^{19}$ F NMR ( $565 \mathrm{MHz}$, Acetone- $\mathrm{d}_{6}$ )

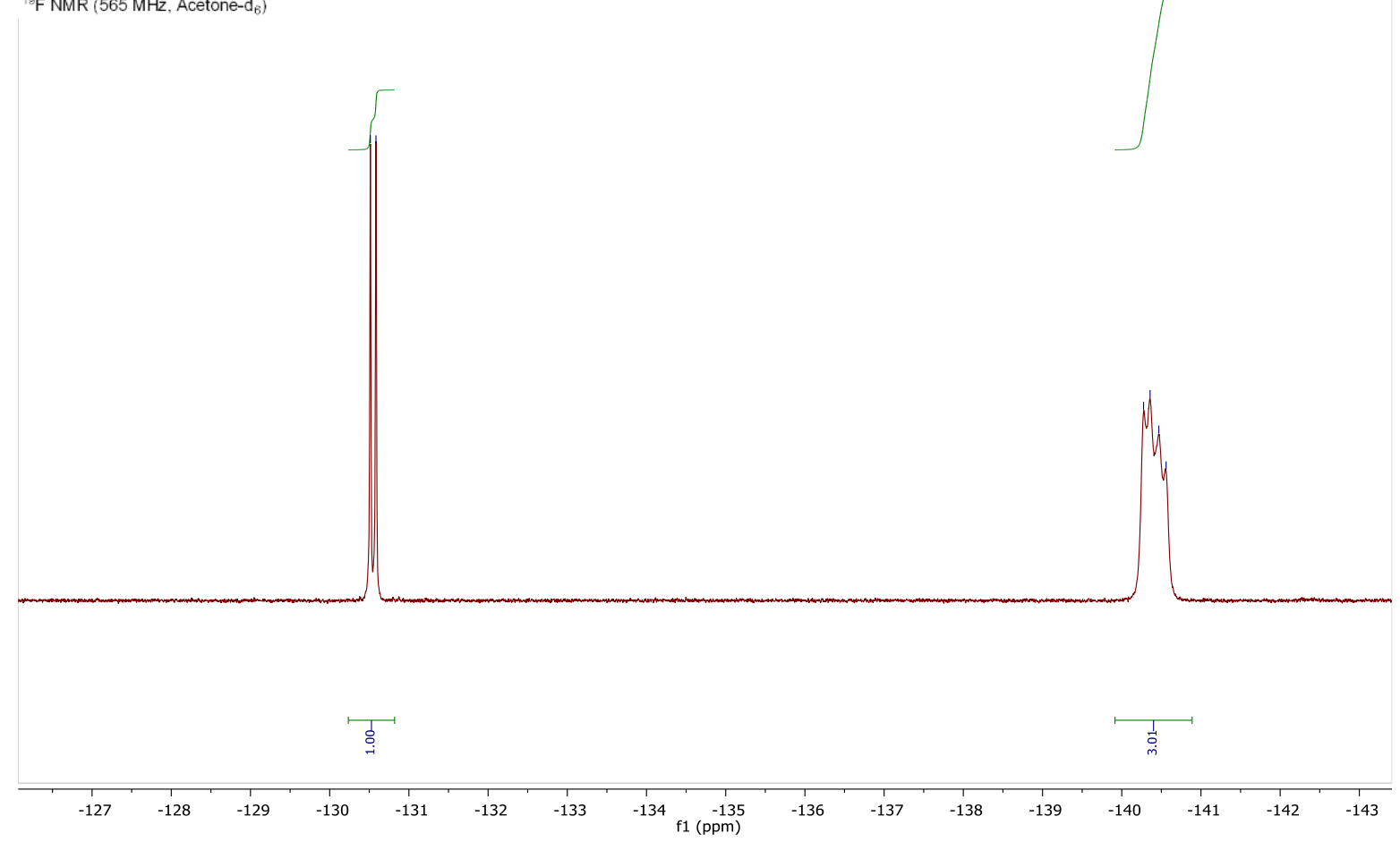




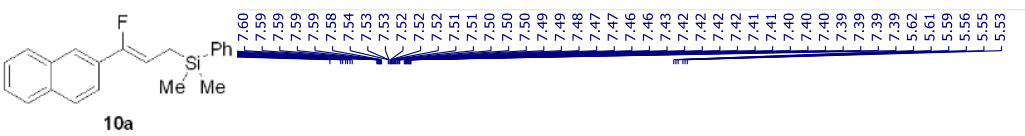

${ }^{1} \mathrm{H} \mathrm{NMR}\left(600 \mathrm{MHz}, \mathrm{CDCl}_{3}\right)$<smiles>C1#CC#CC#CC#C1</smiles>
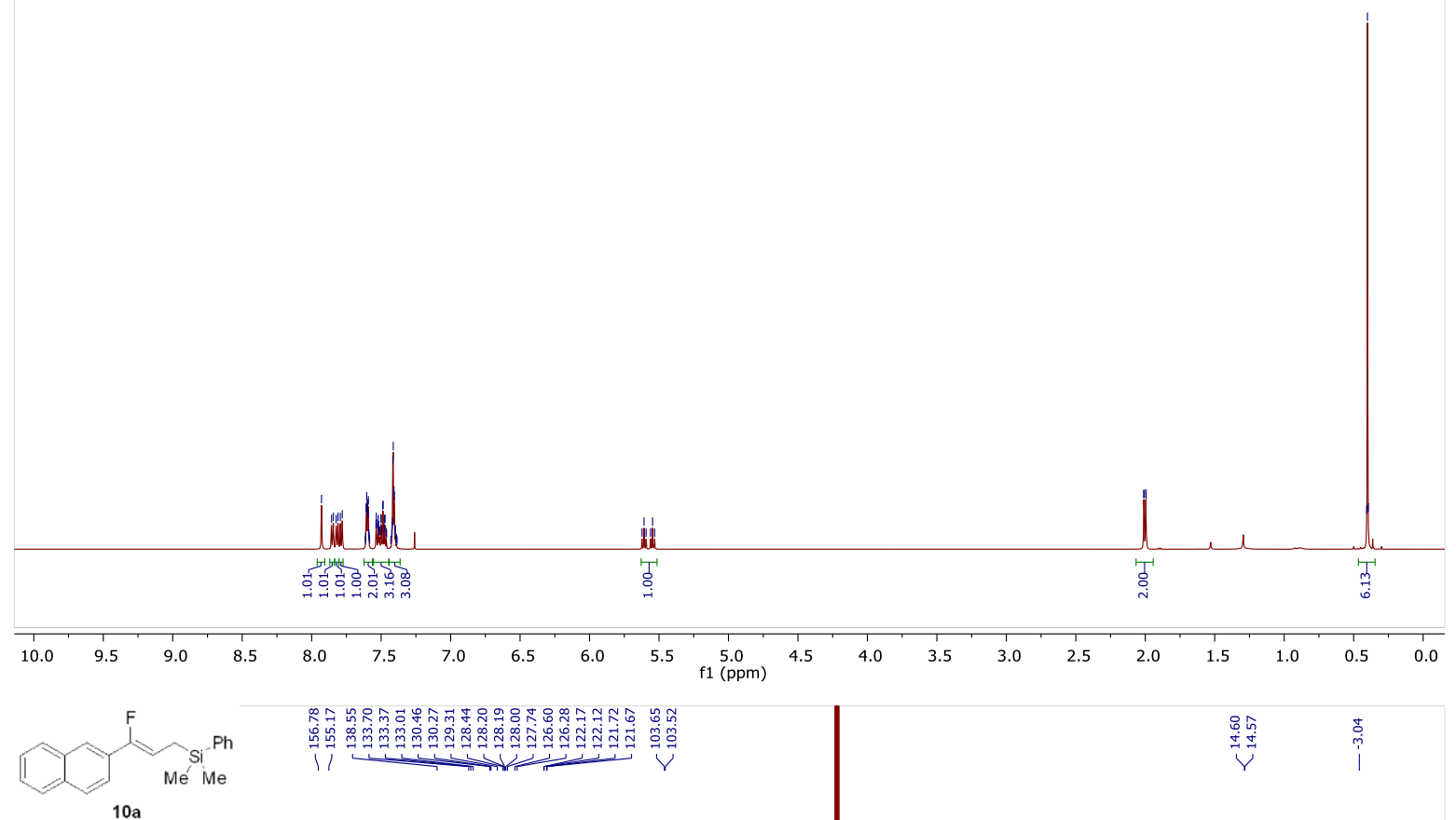

${ }^{13} \mathrm{C}$ NMR $\left(151 \mathrm{MHz}, \mathrm{CDCl}_{3}\right)$

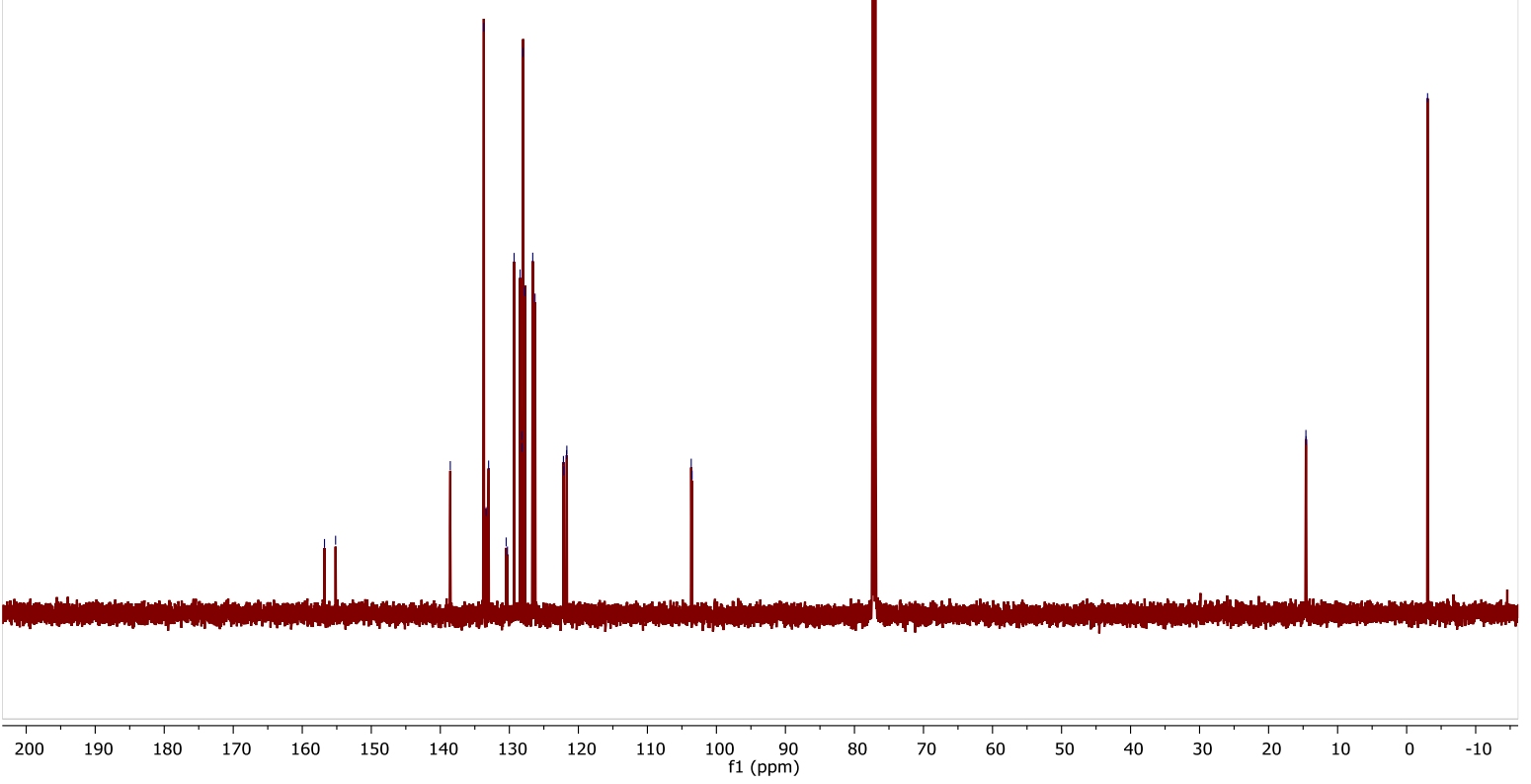




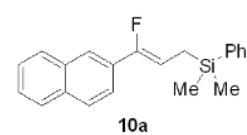

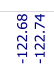

${ }^{19} \mathrm{~F} \mathrm{NMR}\left(565 \mathrm{MHz}, \mathrm{CDCl}_{3}\right)$

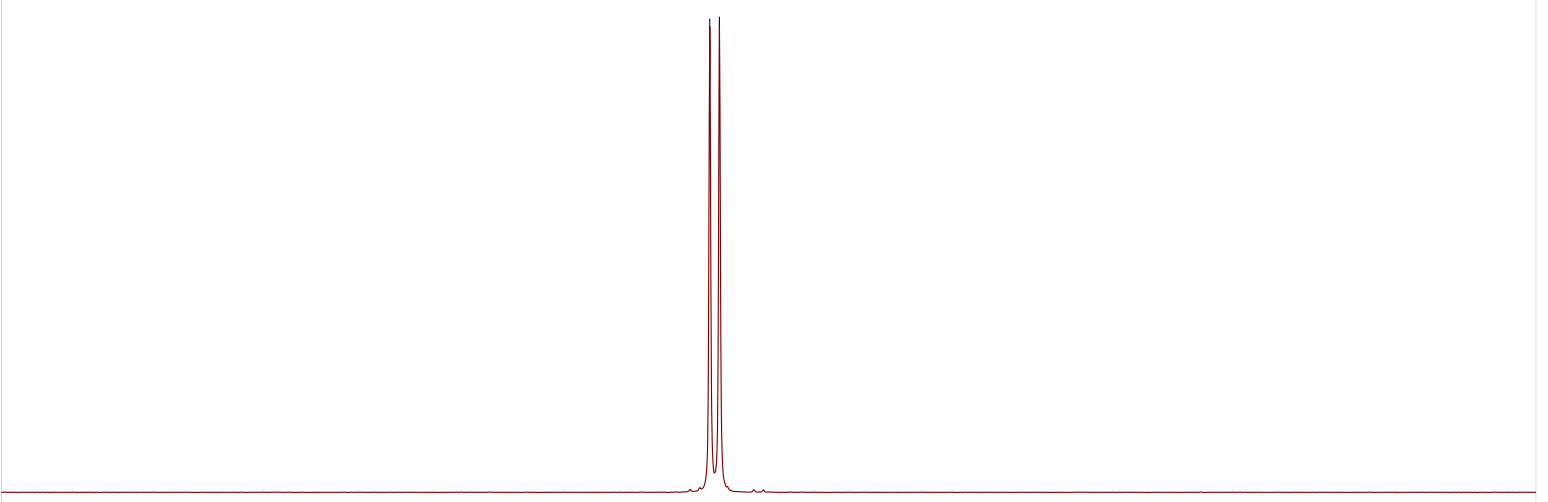

$\begin{array}{llllllllllllllllllllll}118.0 & -118.5 & -119.0 & -119.5 & -120.0 & -120.5 & -121.0 & -121.5 & -122.0 & -122.5 & -123.0 & -123.5 & -124.0 & -124.5 & -125.0 & -125.5 & -126.0 & -126.5 & -127.0 & -127.5 & -128.0\end{array}$ 


\section{Crude ${ }^{1} \mathrm{H}$ AND ${ }^{19}$ F NMR SPECTRA}

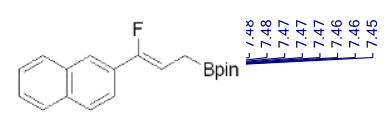

2a

${ }^{1} \mathrm{H} \mathrm{NMR}\left(600 \mathrm{MHz}, \mathrm{CDCl}_{3}\right)$

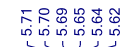

네

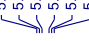

(n)

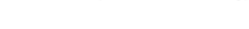

(n)

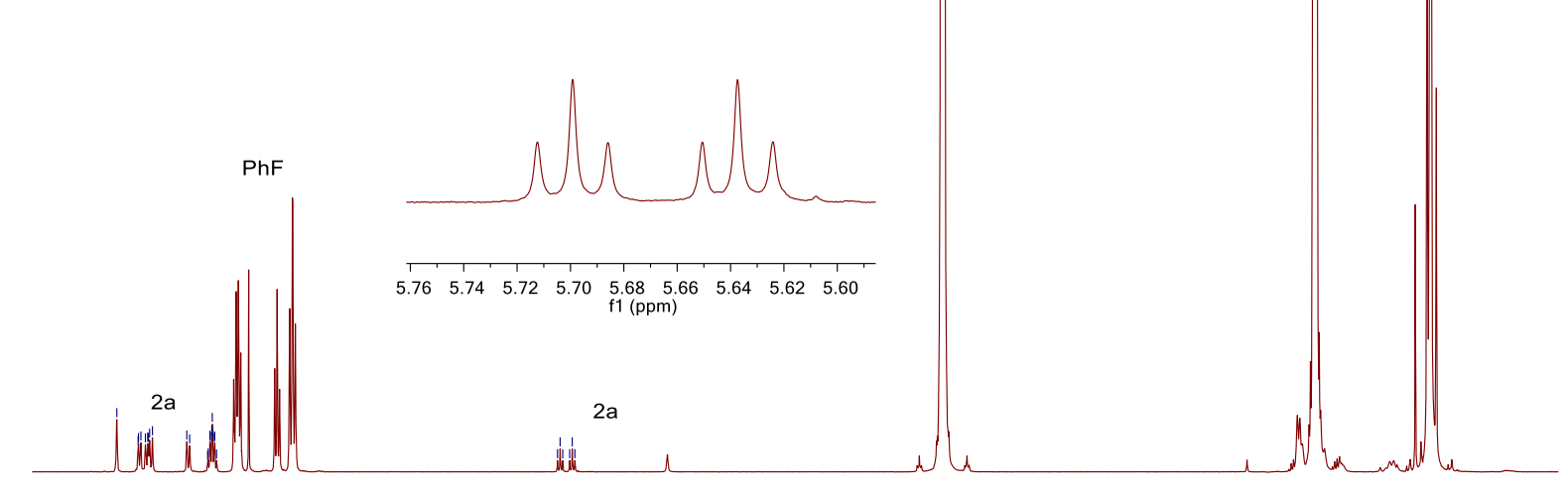

豈

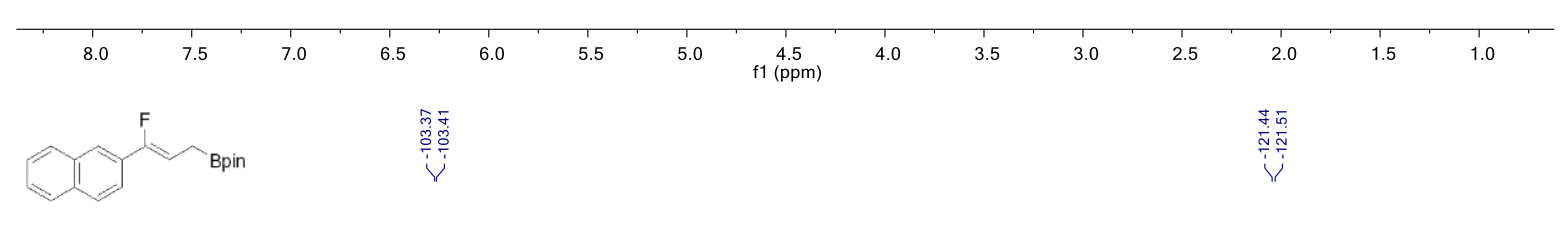

$2 a$

${ }^{19} \mathrm{~F} \mathrm{NMR}\left(565 \mathrm{MHz}, \mathrm{CDCl}_{3}\right)$

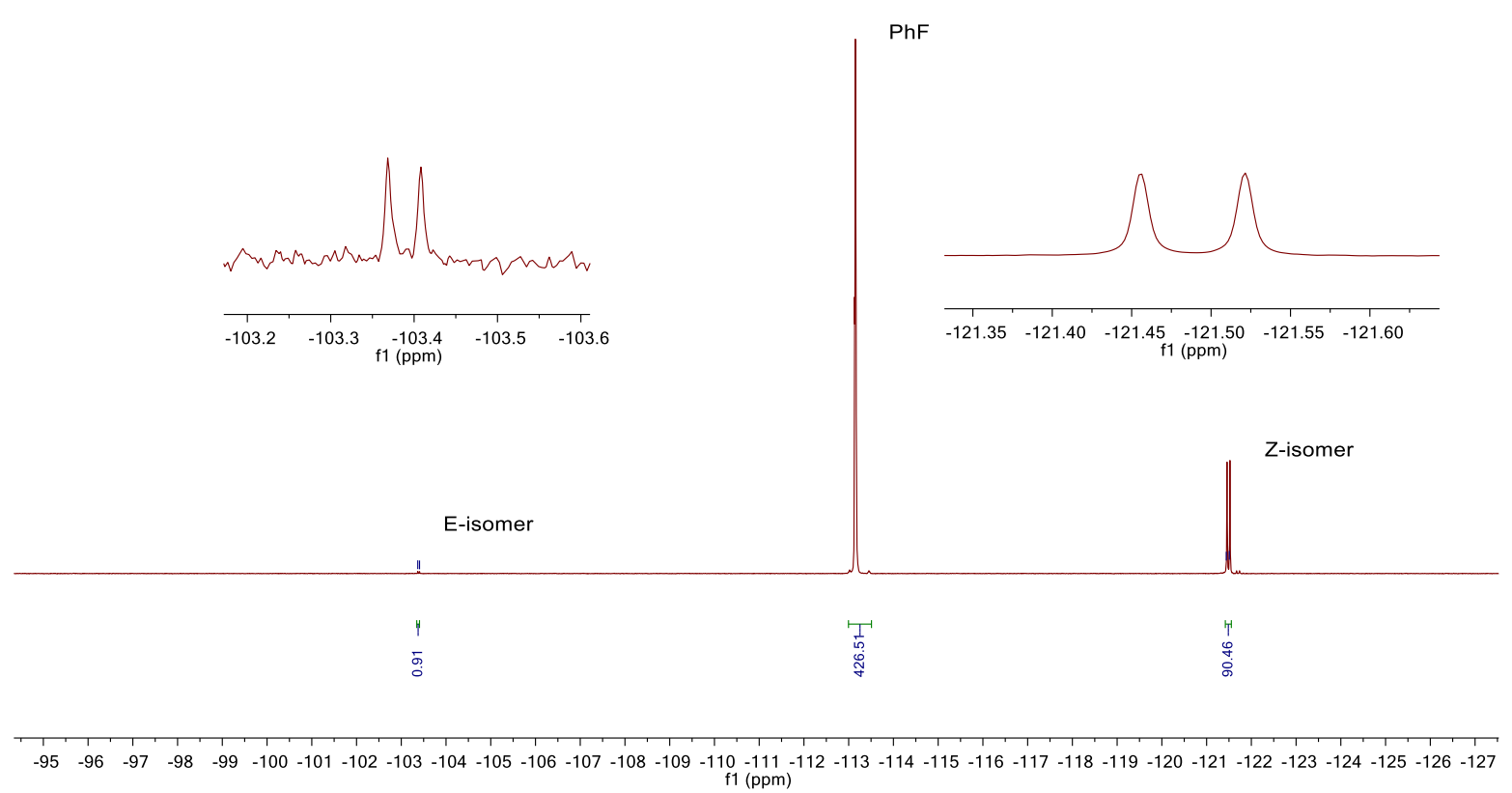




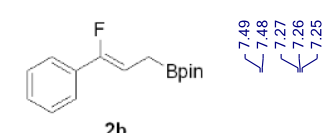

${ }^{1} \mathrm{H} \mathrm{NMR}\left(600 \mathrm{MHz}, \mathrm{CDCl}_{3}\right)$

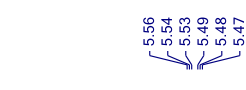

$\underbrace{4}$

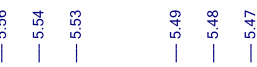

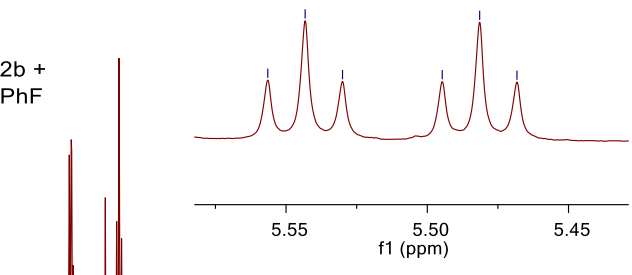

$2 b$ witi

管
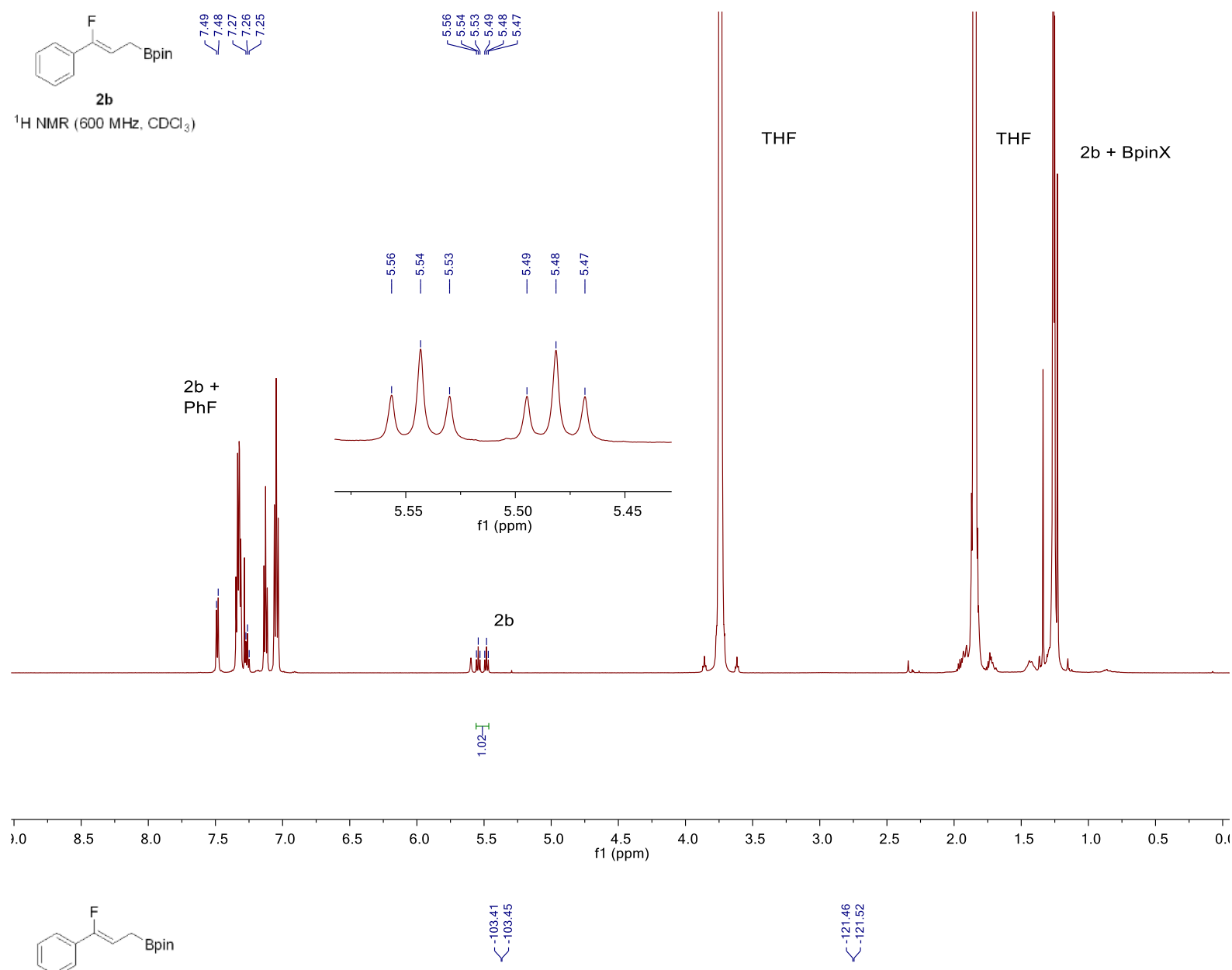

$2 \mathrm{~b}$

${ }^{19} \mathrm{~F} \mathrm{NMR}\left(565 \mathrm{MHz}, \mathrm{CDCl}_{3}\right)$

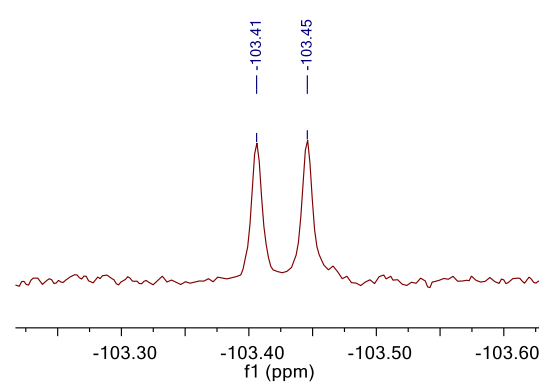

$\mathrm{PhF}$

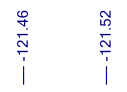

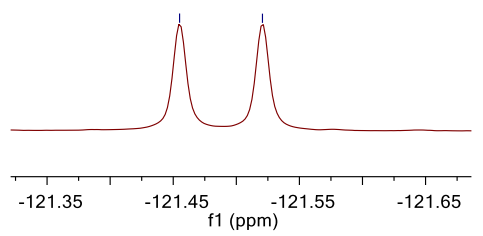

major Z-isomer

minor E-isomer

minor E-isomer

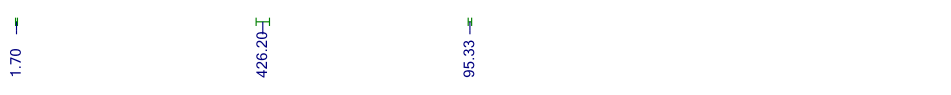

$\begin{array}{llllllllllllllllllllllllllllllllll}-80 & -82 & -84 & -86 & -88 & -90 & -92 & -94 & -96 & -98 & -100 & -102 & -104 & -106 & -108 & -110 & -112 & -114 & -116 & -118 & -120 & -122 & -124 & -126 & -128 & -130 & -132 & -134 & -136 & -138 & -140\end{array}$ f1 (ppm) 

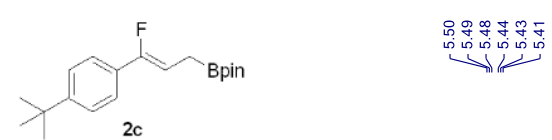

${ }^{1} \mathrm{H} \mathrm{NMR}\left(600 \mathrm{MHz}, \mathrm{CDCl}_{3}\right)$

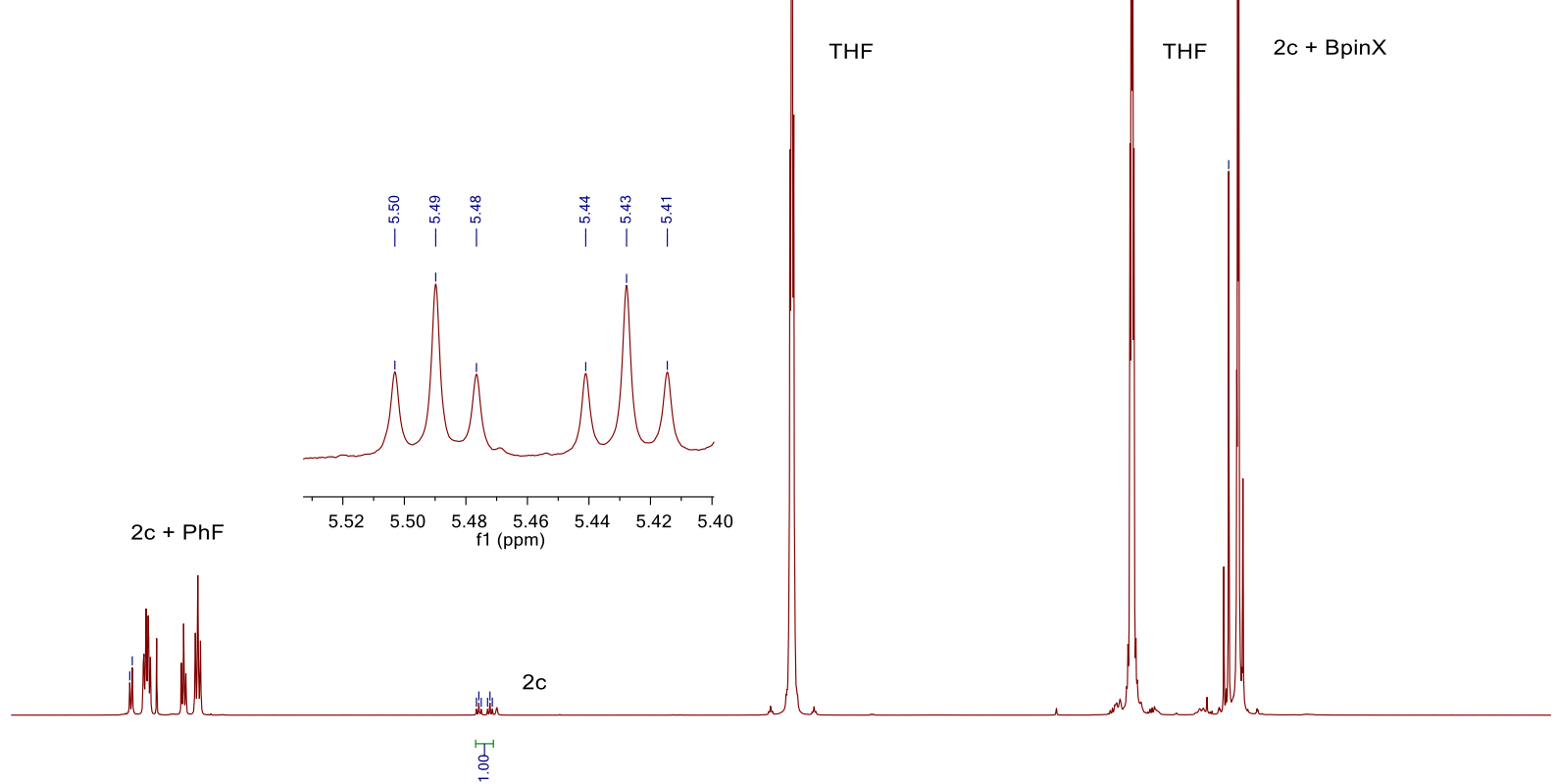

\begin{tabular}{|c|c|c|c|c|c|c|c|c|c|c|c|}
\hline 8.0 & 7.5 & 7.0 & 6.5 & 6.0 & 5.5 & 5.0 & 4.5 & ${ }_{\mathrm{f} 1(\mathrm{ppm})}^{3.5}$ & 3.0 & 2.5 & 2.0 \\
\hline & & Bpin & & & & & & & & & \\
\hline
\end{tabular}

${ }^{19} \mathrm{~F} \mathrm{NMR}\left(565 \mathrm{MHz}, \mathrm{CDCl}_{3}\right)$
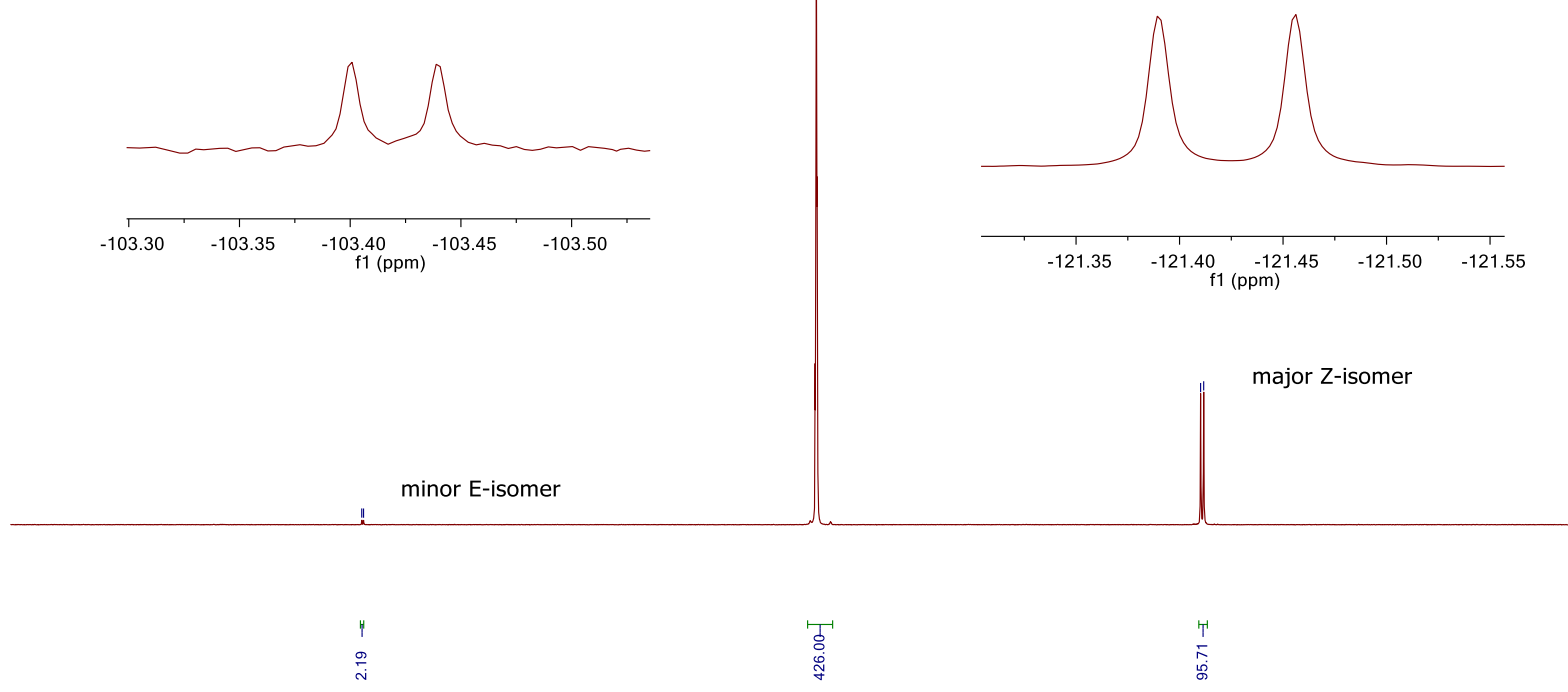

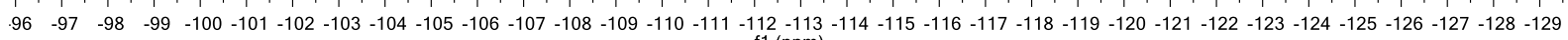
f1 (ppm) 


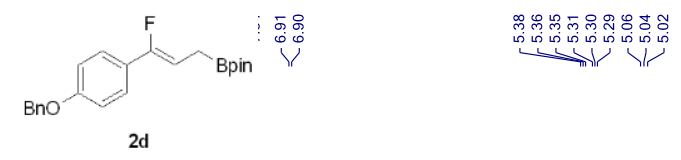

${ }^{1} \mathrm{H} \mathrm{NMR}\left(600 \mathrm{MHz}, \mathrm{CDCl}_{3}\right.$ )
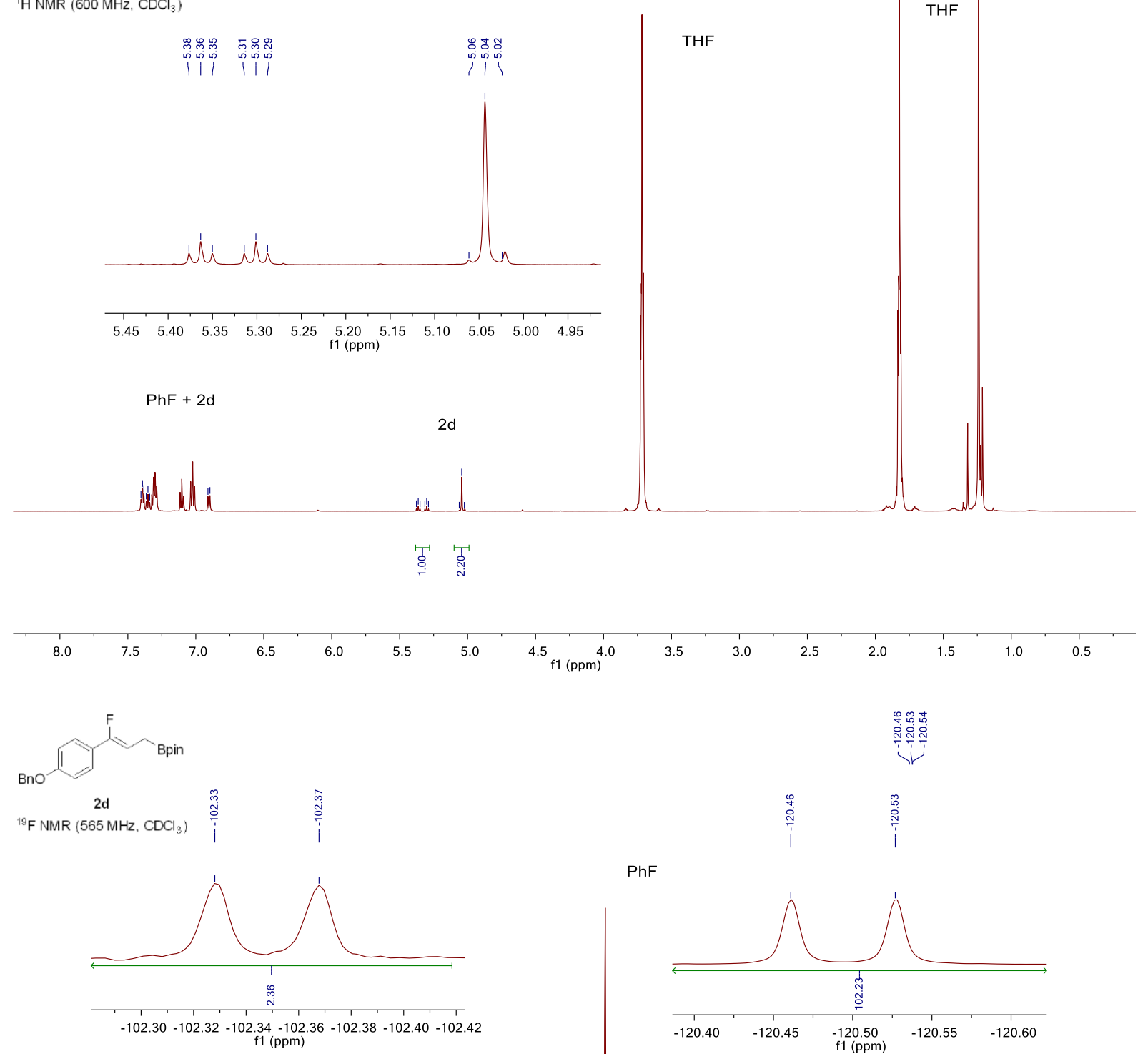

PhF

minor E-isomer
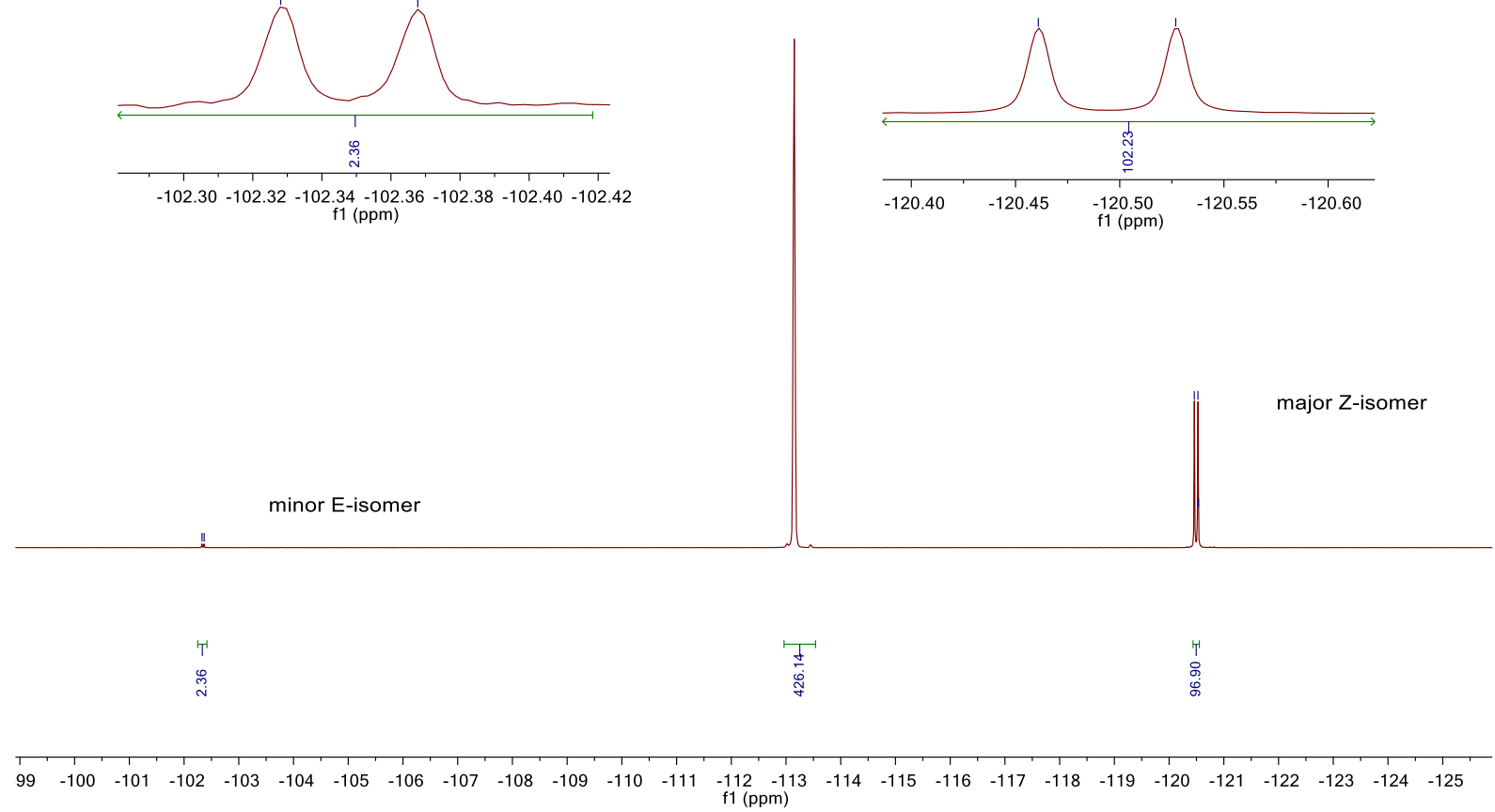


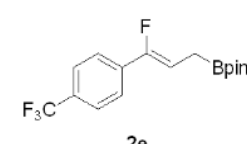

${ }^{1} \mathrm{H} \mathrm{NMR}\left(600 \mathrm{MHz}, \mathrm{CDCl}_{3}\right)$

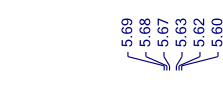

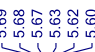

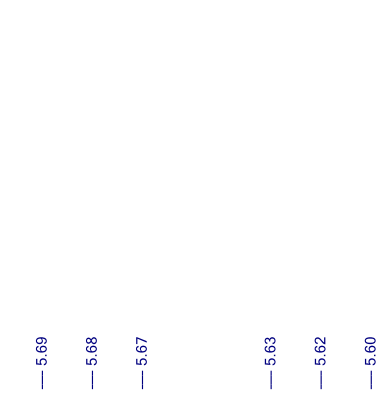

THF

THF

BpinX
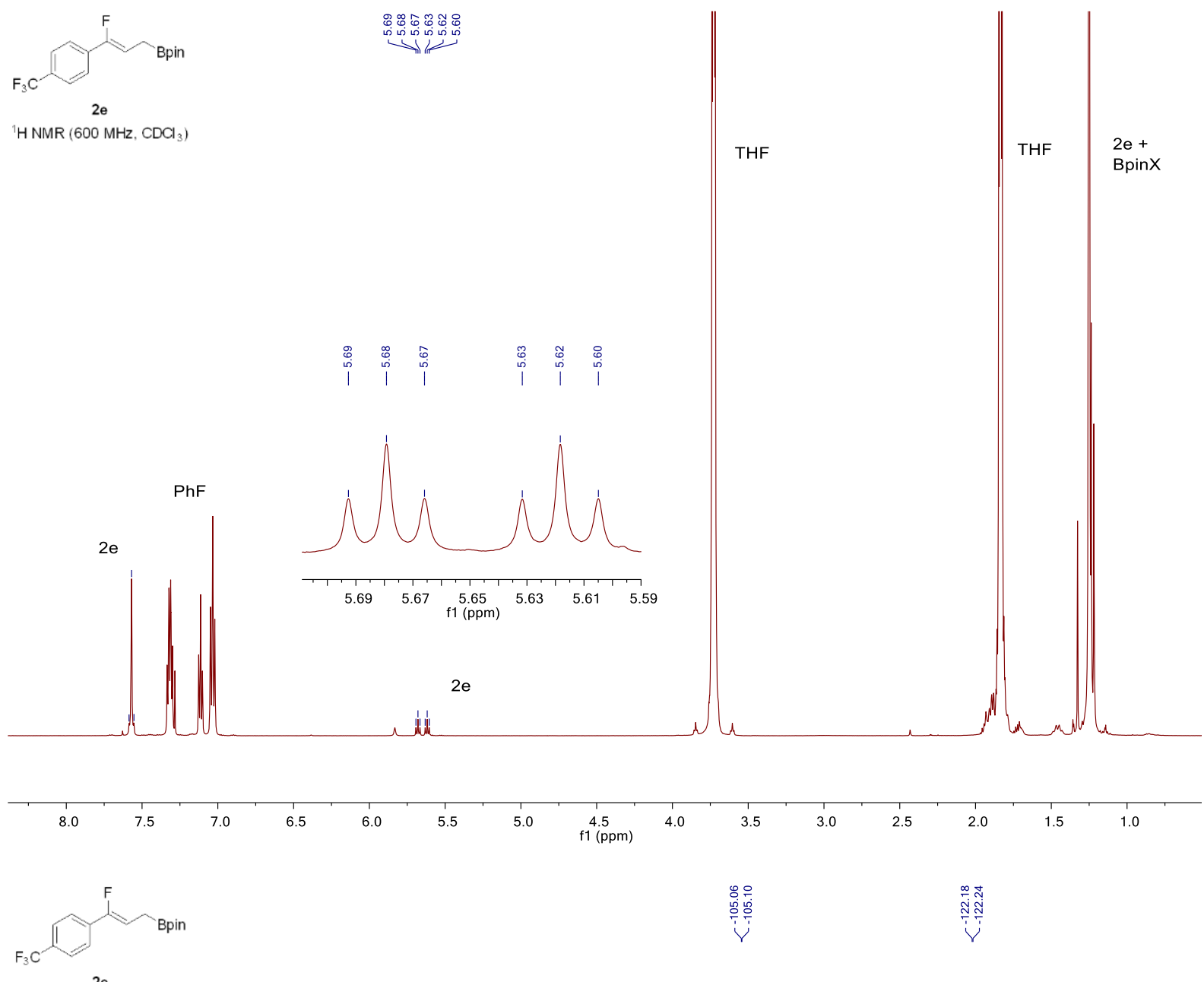

ํㅜㄴ

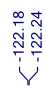

${ }^{19} \mathrm{~F} \mathrm{NMR}\left(565 \mathrm{MHz}, \mathrm{CDCl}_{3}\right)$
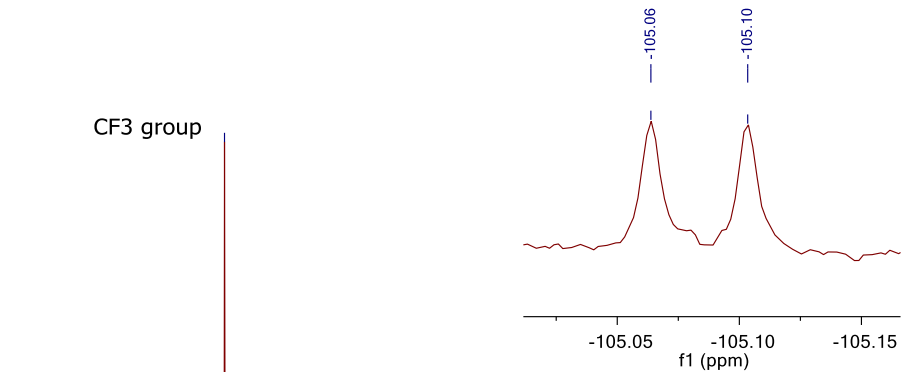
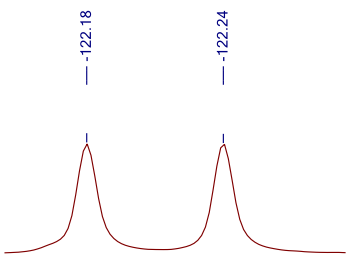

PhF

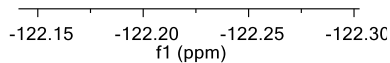

major Z-

isomer

minor E-

isomer

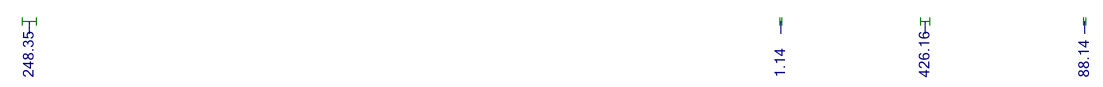

\begin{tabular}{|c|c|c|c|c|c|c|c|c|c|c|c|c|c|c|c|c|}
\hline-55 & -60 & -65 & -70 & -75 & -80 & -85 & -90 & $\begin{array}{c}-95 \\
\mathrm{f} 1(\mathrm{ppm})\end{array}$ & -100 & -105 & -110 & -115 & -120 & -125 & -130 & -135 \\
\hline
\end{tabular}




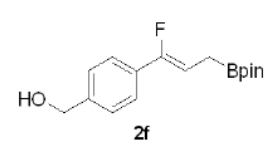

${ }^{1} \mathrm{HNMR}\left(600 \mathrm{MHz}, \mathrm{CDCl}_{3}\right.$ )
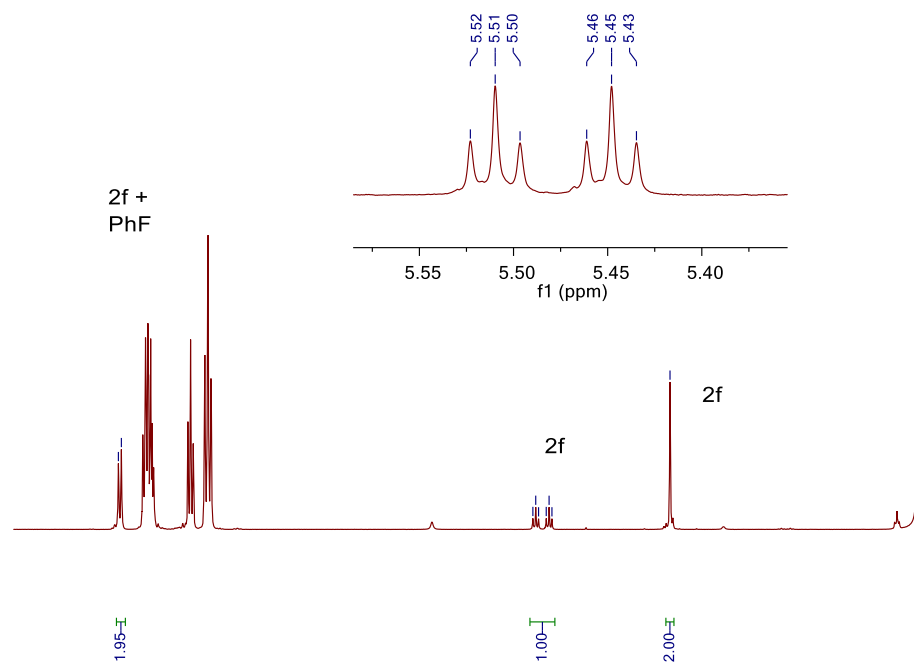

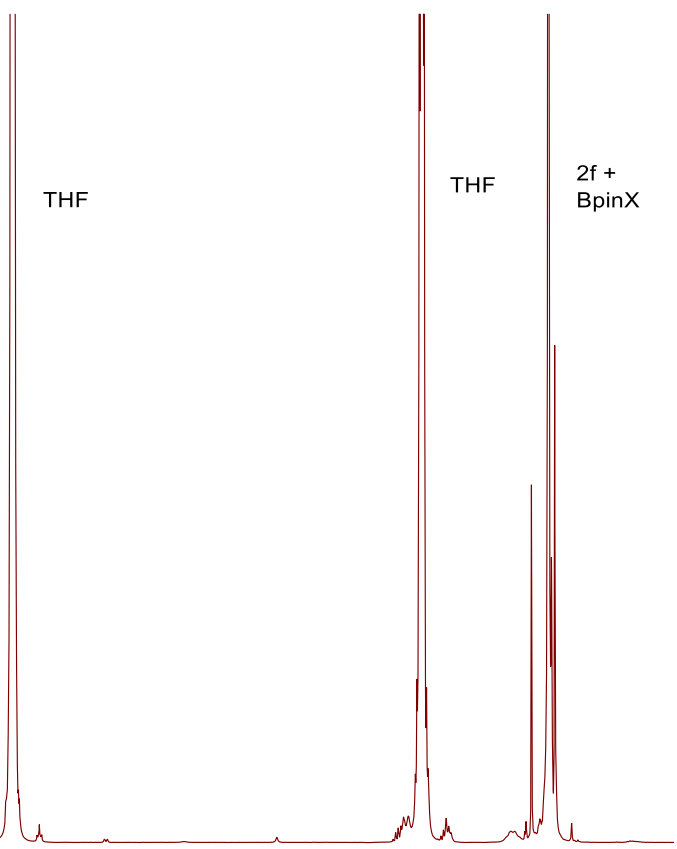

敳

\begin{tabular}{|c|c|c|c|c|c|c|c|c|c|c|c|c|c|}
\hline 7.5 & 7.0 & 6.5 & 6.0 & 5.5 & 5.0 & 4.5 & 4.0 & 3.5 & 3.0 & 2.5 & 2.0 & 1.5 & 1.0 \\
\hline
\end{tabular}

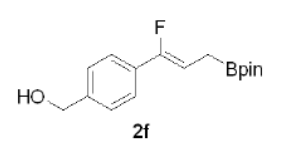

${ }^{19} \mathrm{~F} \mathrm{NMR} \mathrm{(} 565 \mathrm{MHz}, \mathrm{CDCl}_{3}$ )

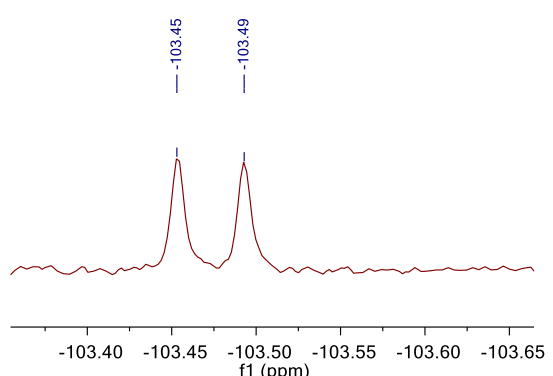
f1 (ppm)
PhF

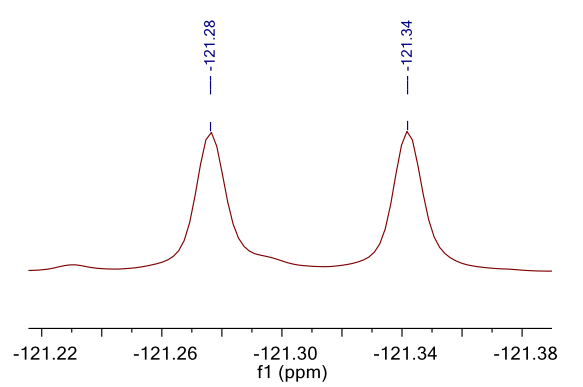

major Z-isomer

minor E-isomer

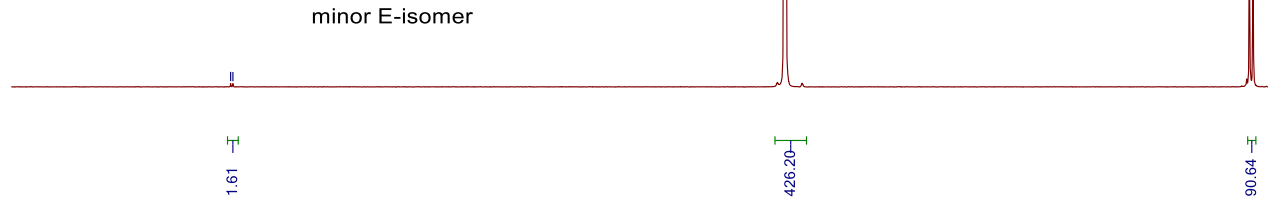

\begin{tabular}{lllllllllllllllllllllllllllllllllllllllllllll}
\hline & -100 & -101 & -102 & -103 & -104 & -105 & -106 & -107 & -108 & -109 & -110 & -111 & -112 & -113 & -114 & -115 & -116 & -117 & -118 & -119 & -120 & -121 & -122 & -123 & -124 & -125 & -126 & -127
\end{tabular} 


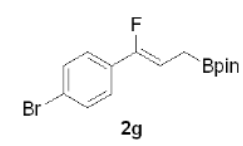

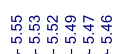

${ }^{1} \mathrm{HNMR}\left(600 \mathrm{MHz}, \mathrm{CDCl}_{3}\right)$
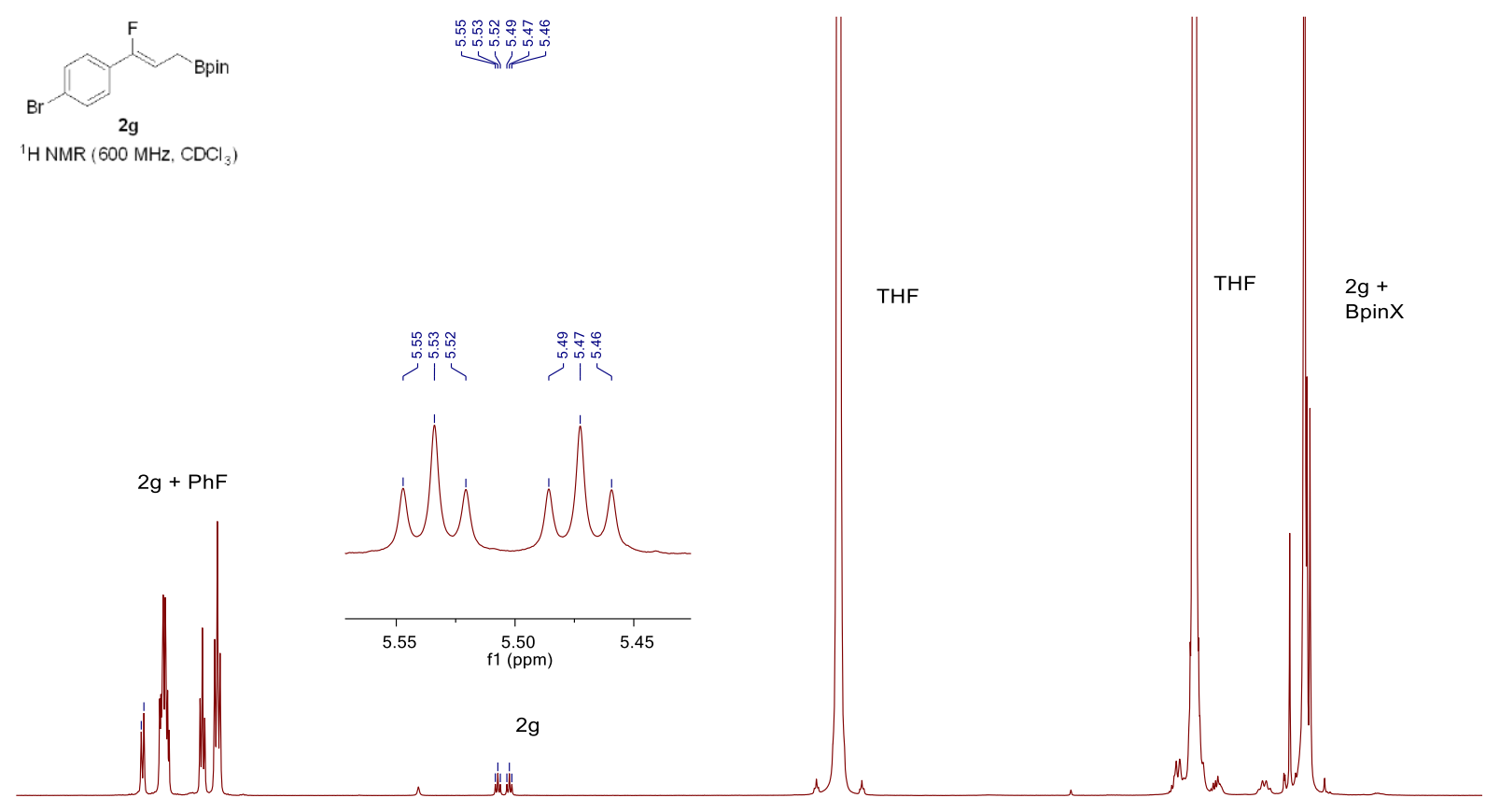

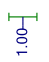

\begin{tabular}{|c|c|c|c|c|c|c|c|c|c|c|c|c|c|}
\hline 8.0 & 7.5 & 7.0 & 6.5 & 6.0 & 5.5 & 5.0 & $\begin{array}{ll}4.5 & \\
\mathrm{f} 1(\mathrm{ppm}) & 4.0\end{array}$ & 3.5 & 3.0 & 2.5 & 2.0 & 1.5 & 1.0 \\
\hline
\end{tabular}

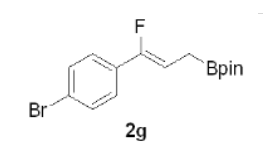

${ }^{19} \mathrm{FNMR}\left(565 \mathrm{MHz}, \mathrm{CDCl}_{3}\right)$

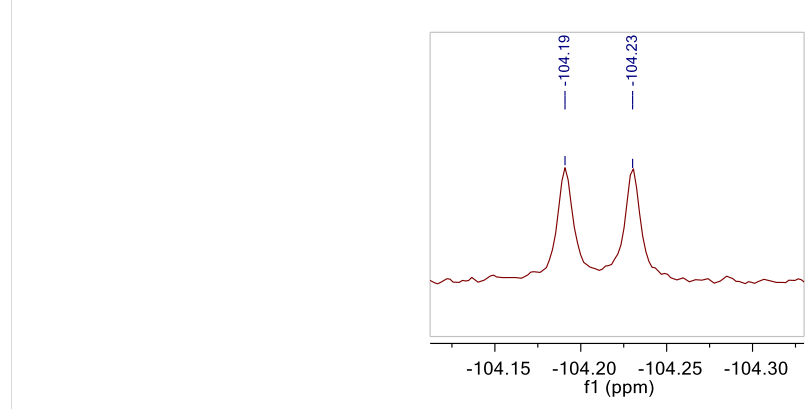

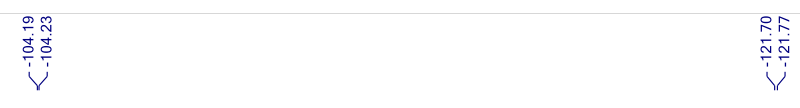

PhF

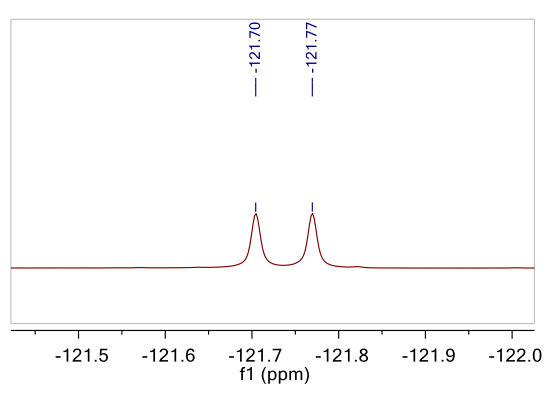

major Z-

isomer

minor E-

isomer

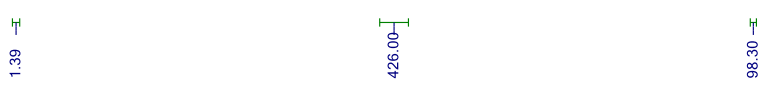



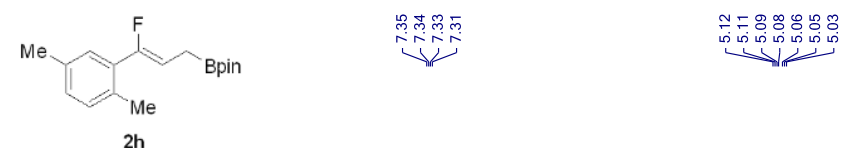

$2 \mathrm{~h}$

${ }^{1} \mathrm{H}$ NMR (600 MHz, $\mathrm{CDCl}_{3}$ )

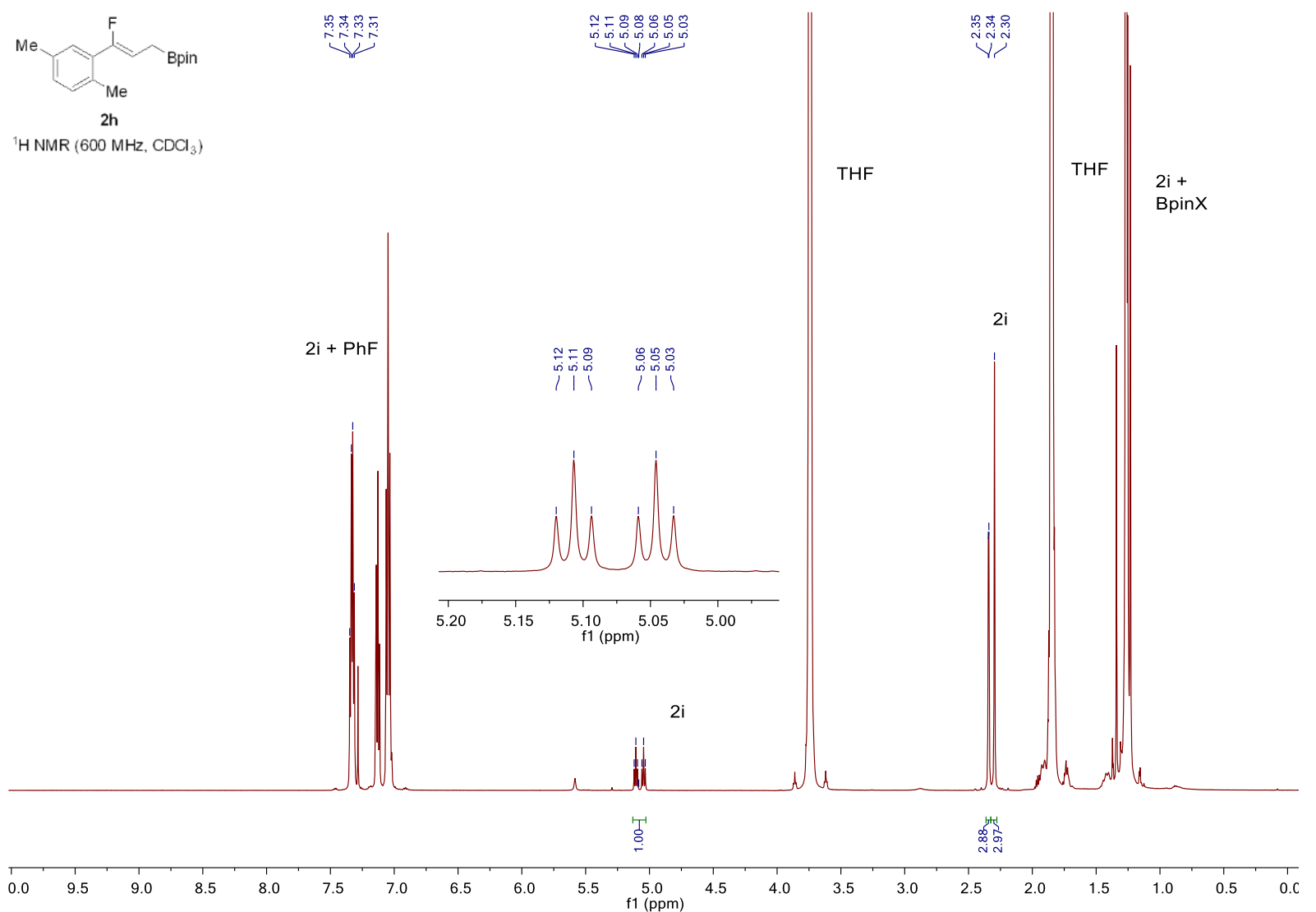

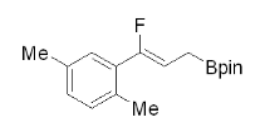

$2 \mathrm{~h}$

${ }^{19} \mathrm{~F} \mathrm{NMR}\left(565 \mathrm{MHz}, \mathrm{CDCl}_{3}\right)$

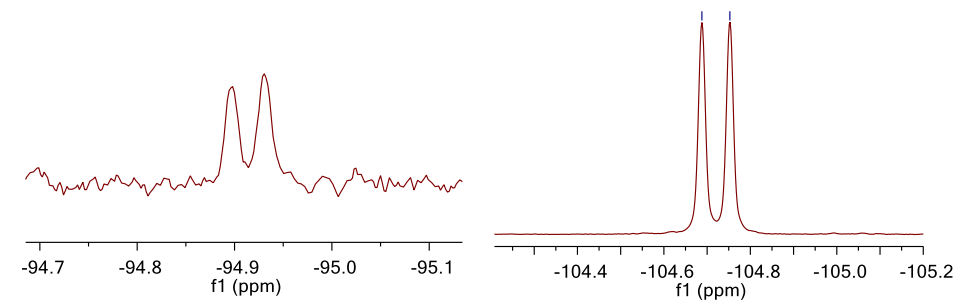

ำ

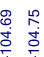

임

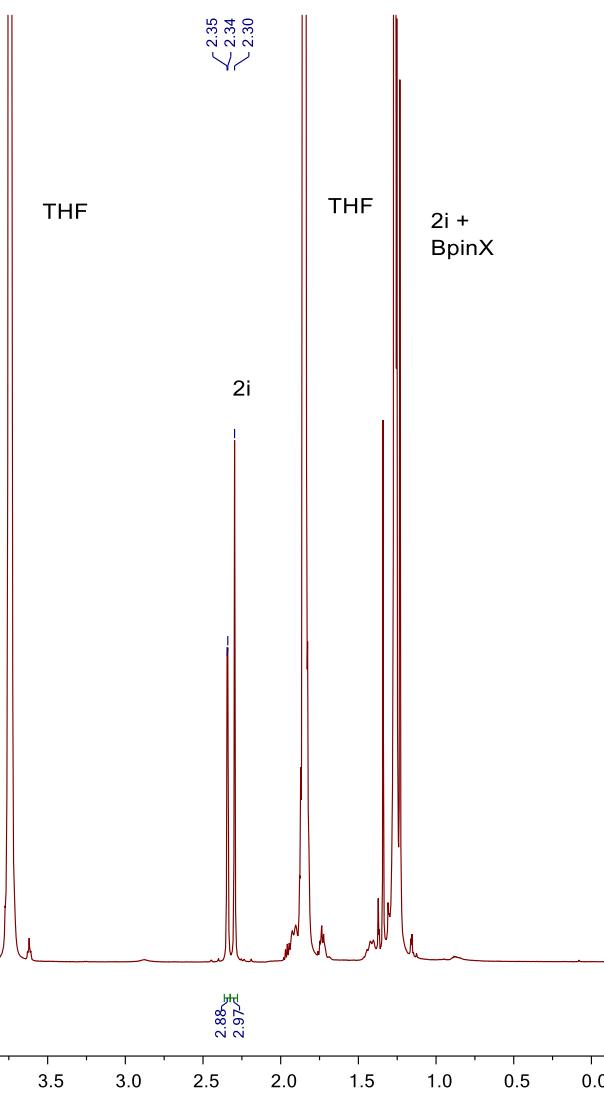

PhF

Z-isomer

E-isomer
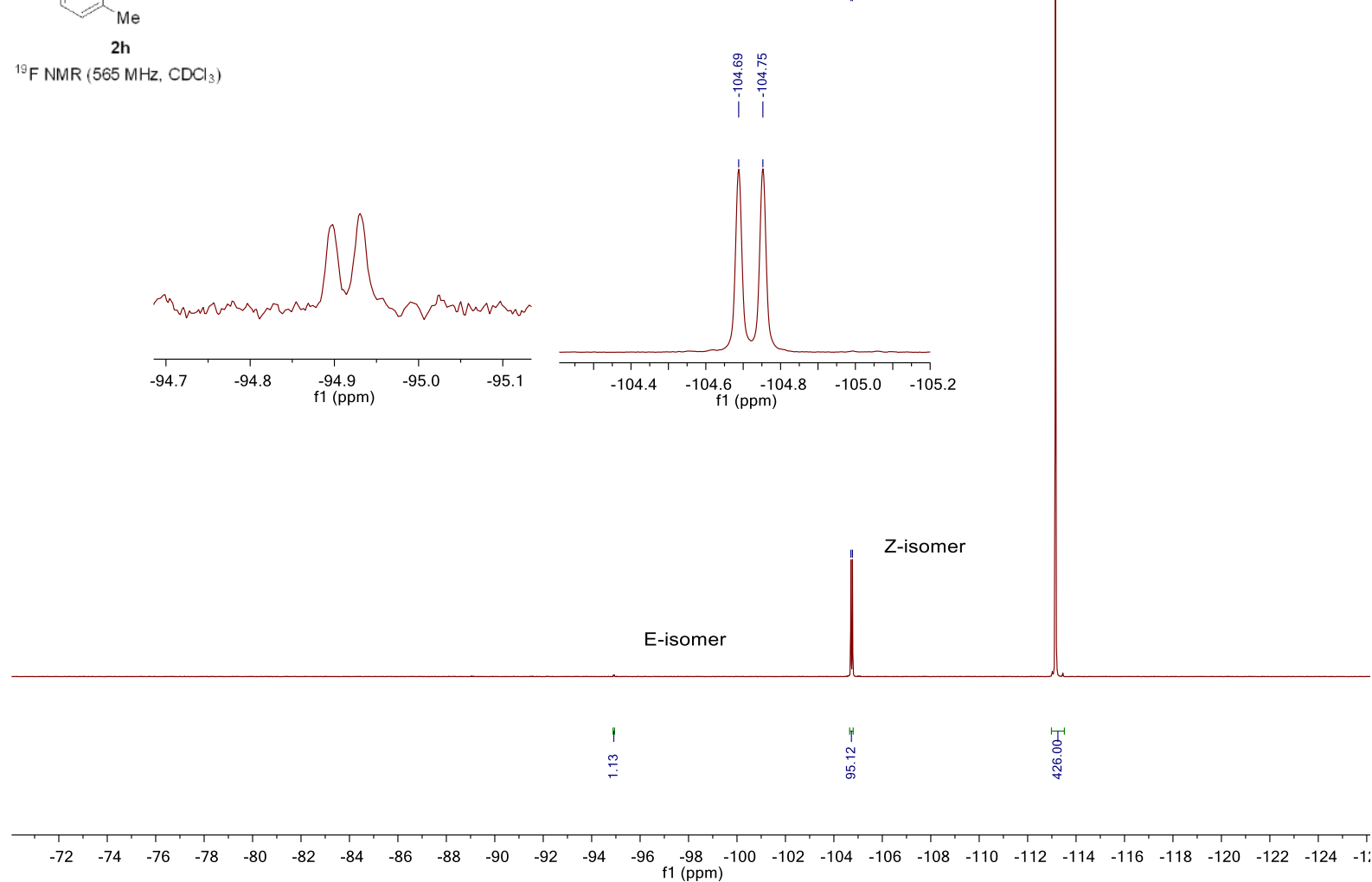


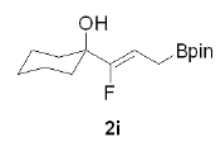

'H NMR ( $600 \mathrm{MHz}, \mathrm{CDCl}_{3}$ )

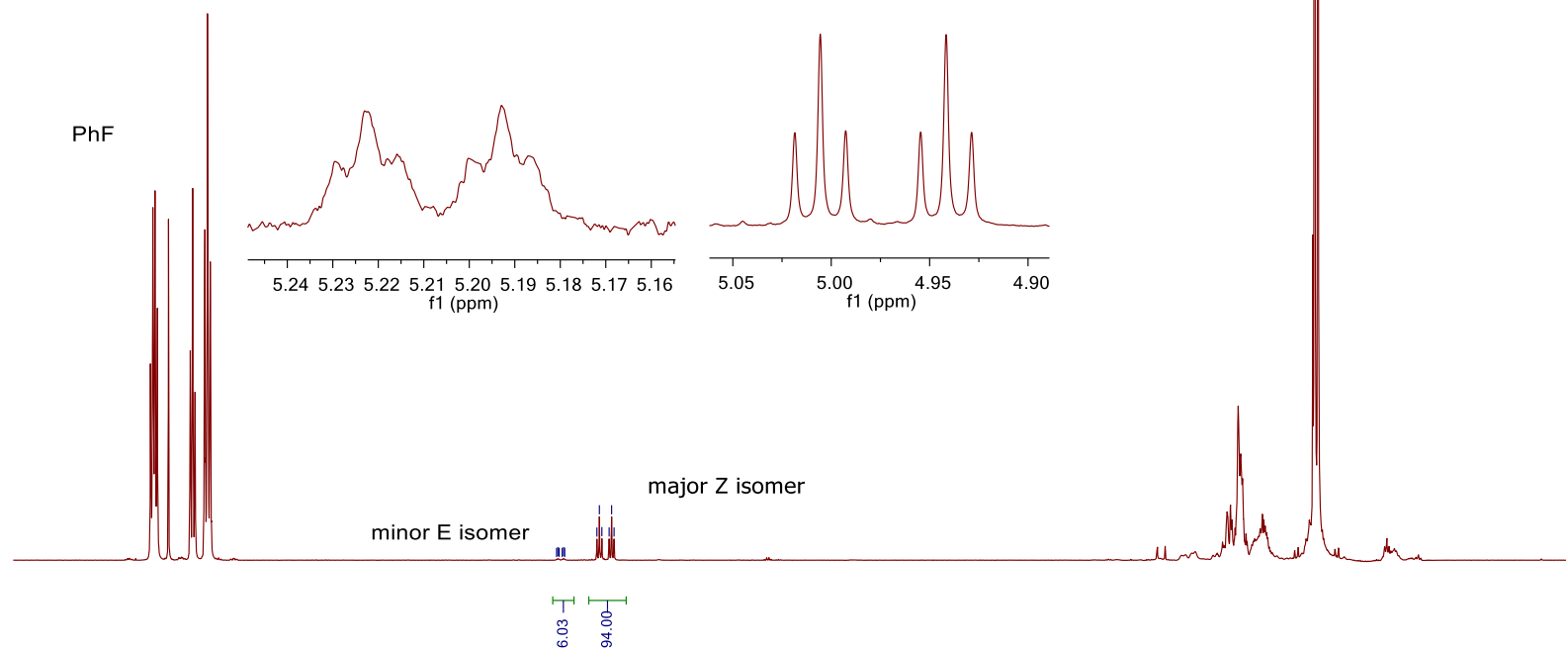

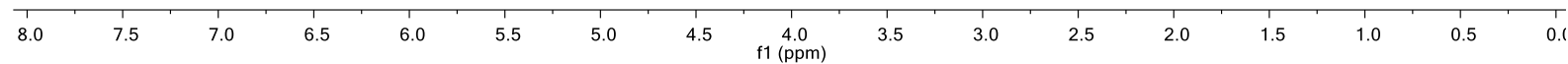

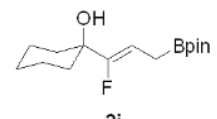

$\left.{ }^{19} \mathrm{~F} \mathrm{NMR} \mathrm{(565} \mathrm{MHz,} \mathrm{CDCl}_{3}\right)$

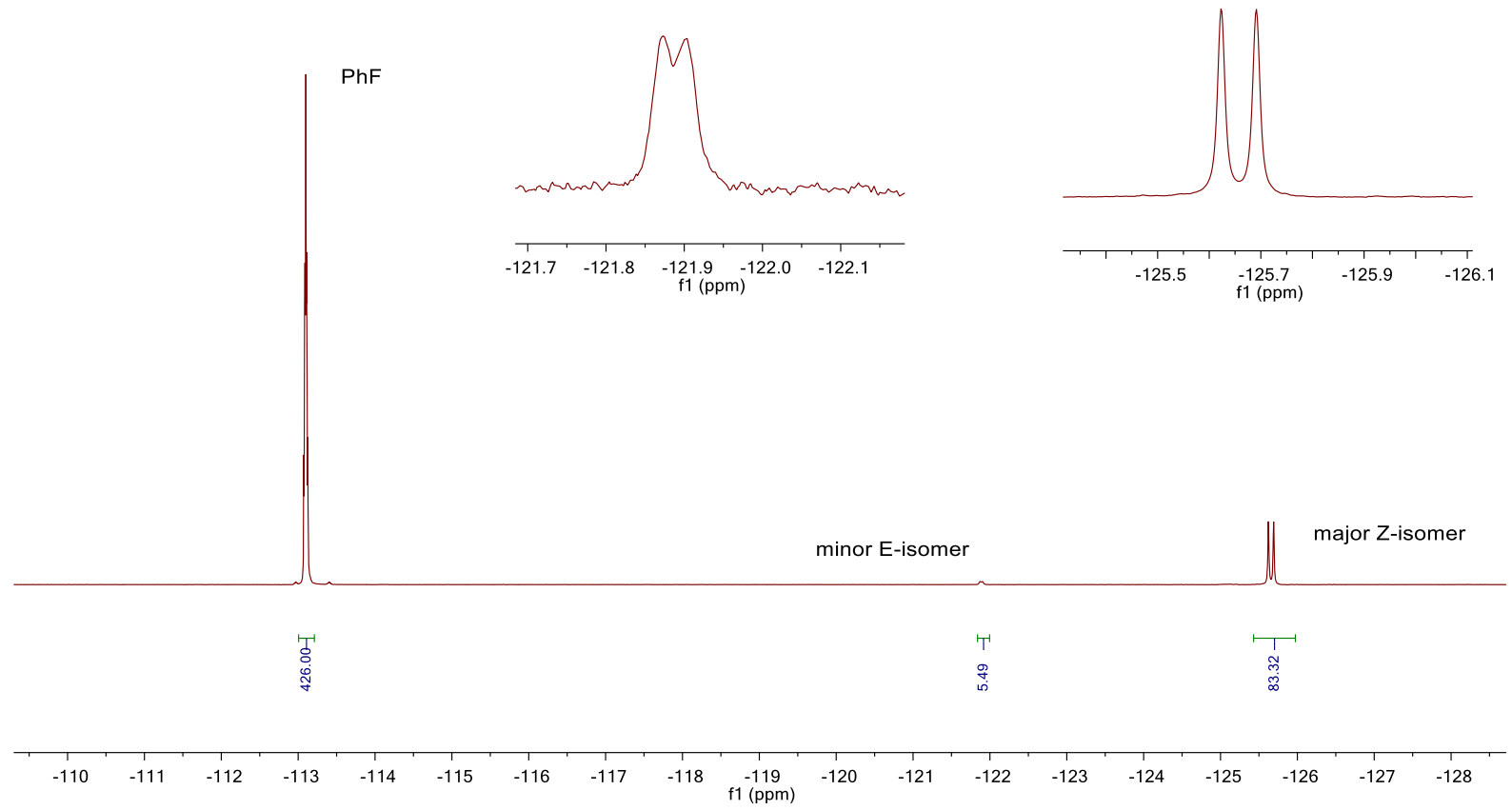




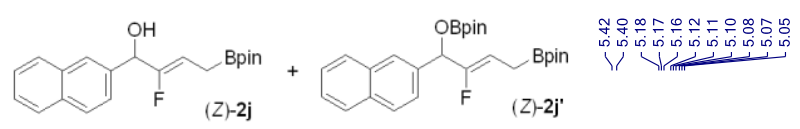

${ }^{1} \mathrm{H} \mathrm{NMR}\left(600 \mathrm{MHz}, \mathrm{CDCl}_{3}\right)$

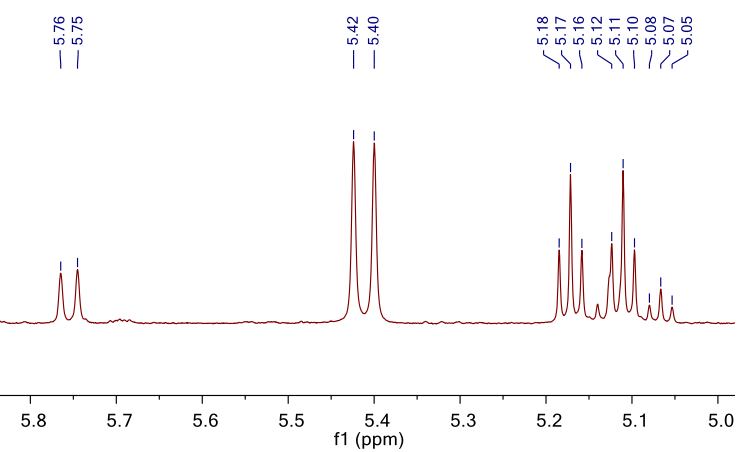

Xantphos + PhF
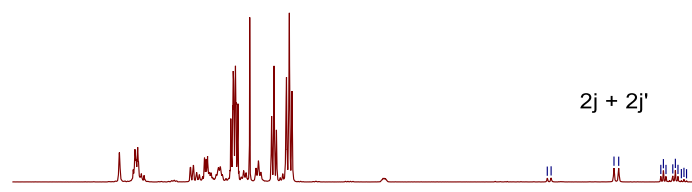

告

\begin{tabular}{|c|c|c|c|c|c|c|c|c|c|c|c|c|c|c|c|}
\hline 8.0 & 7.5 & 7.0 & 6.5 & 6.0 & 5.5 & 5.0 & $\begin{array}{c}4.5 \\
\mathrm{f} 1(\mathrm{ppm})\end{array}$ & 4.0 & 3.5 & 3.0 & 2.5 & 2.0 & 1.5 & 1.0 & 0. \\
\hline
\end{tabular}

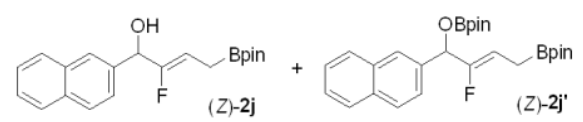

${ }^{19} \mathrm{~F} \mathrm{NMR} \mathrm{(565} \mathrm{MHz,} \mathrm{CDCl}_{3}$ )

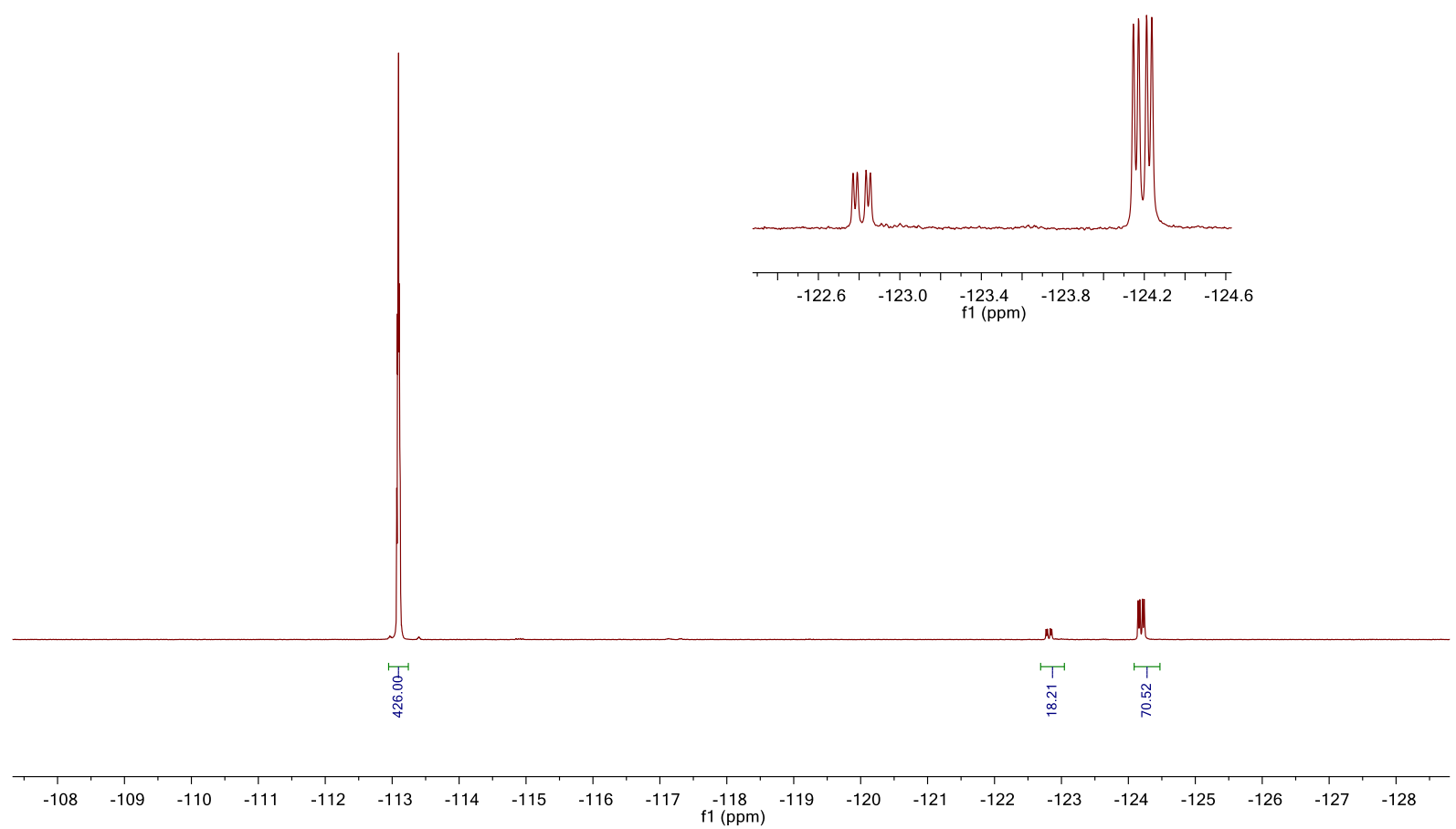




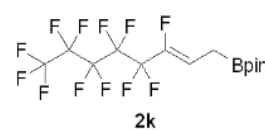

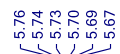

$2 k$

${ }^{1} \mathrm{H} \mathrm{NMR}\left(600 \mathrm{MHz} \mathrm{CDCl}_{3}\right)$

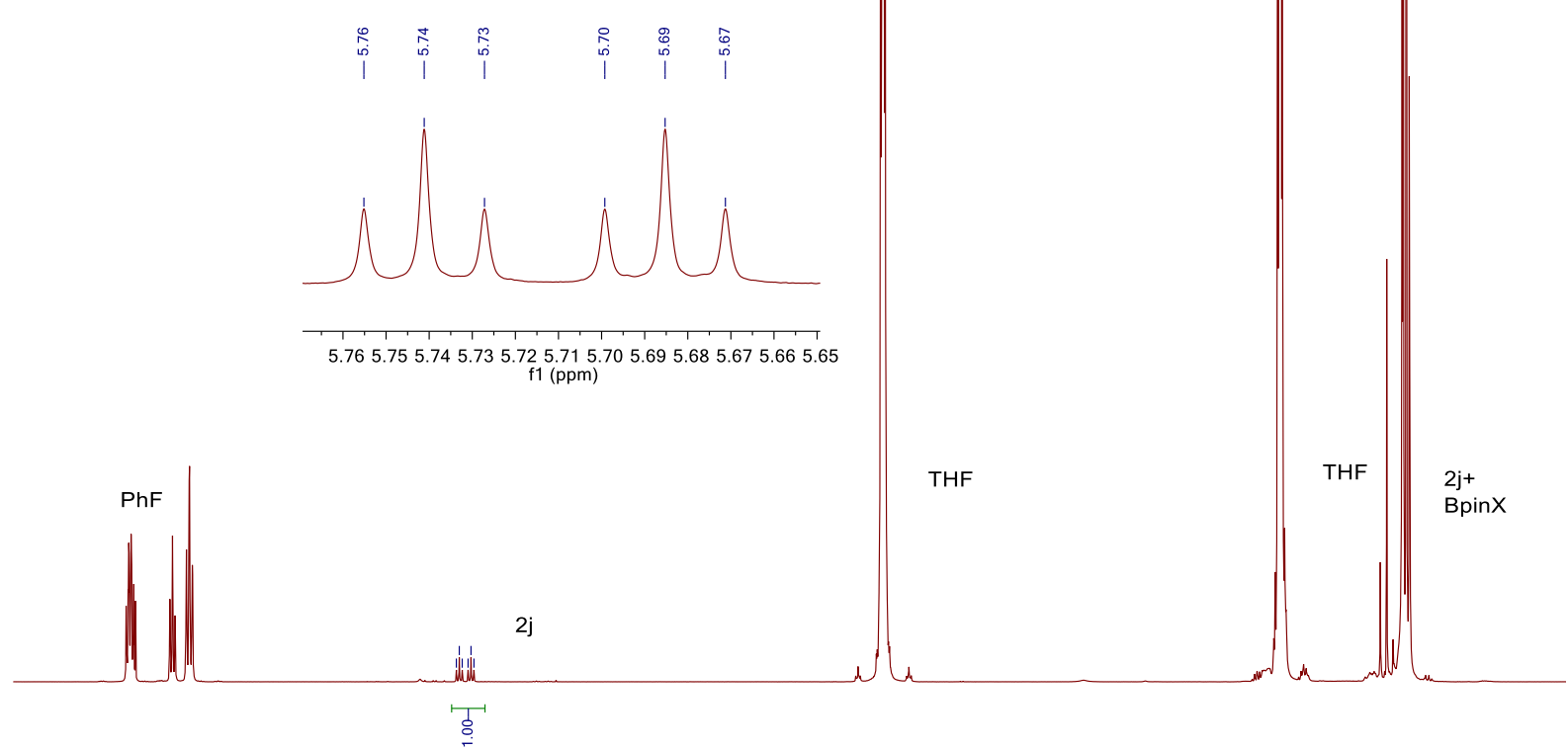

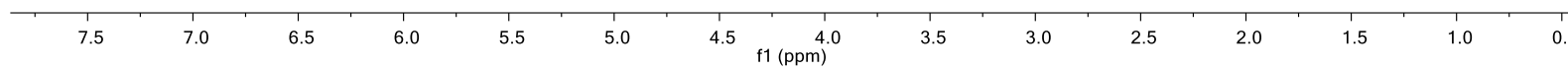

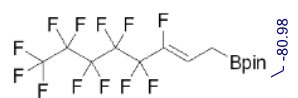

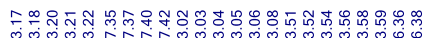

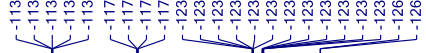

${ }^{19} \mathrm{~F} \mathrm{NMR}\left(565 \mathrm{MHz}, \mathrm{CDCl}_{3}\right)$

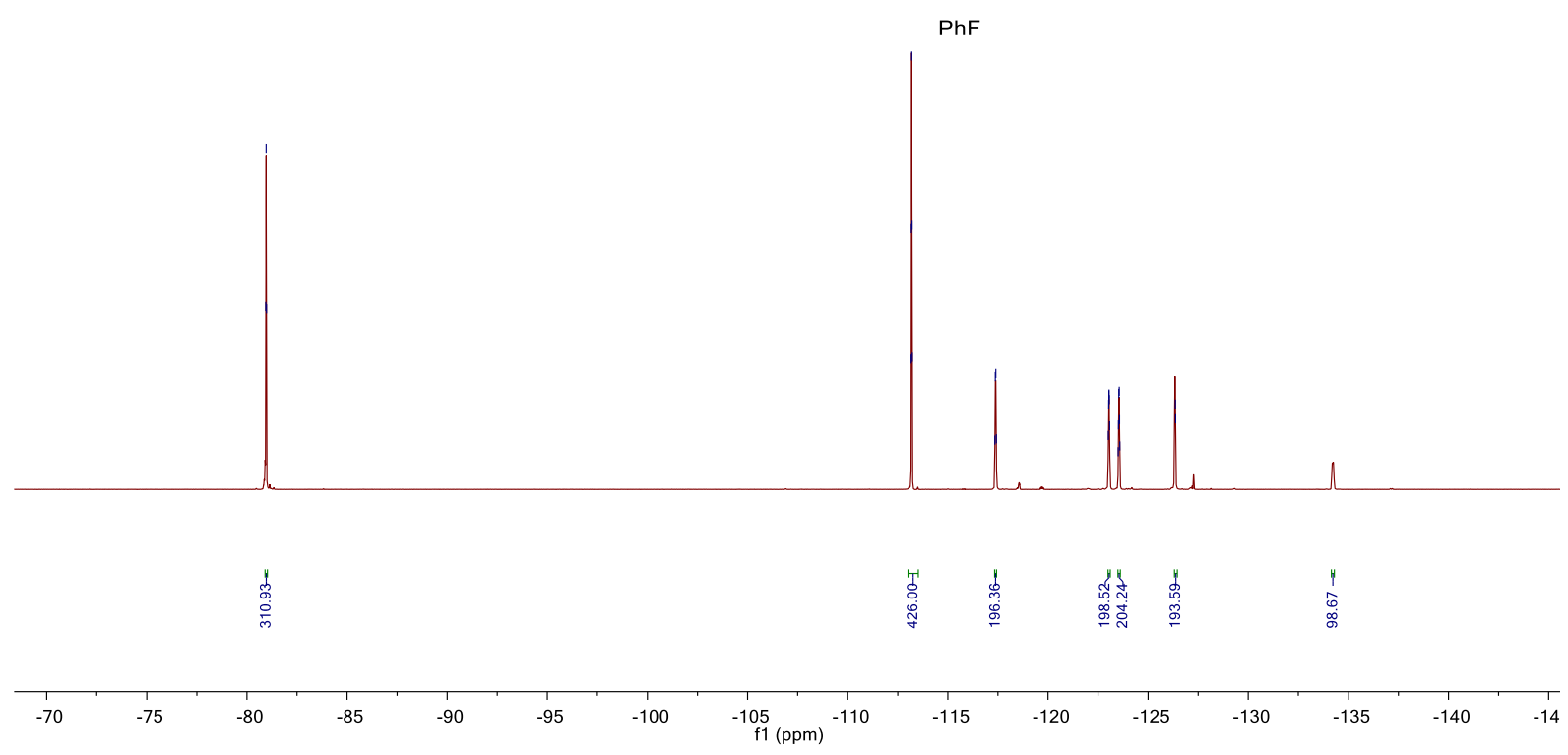

